\title{
BIBLIOGRAFÍA INTERNACIONAL SOBRE LA METAFÍSICA Y LA FILOSOFÍA LA RELIGIÓN DE KANT DESDE 1900
}

\author{
INTERNATIONAL BIBLIOGRAPHY ON METAPHYSIC \\ AND RELIGIONSPHILOSOPHY OF KANT SINCE 1900
}

\author{
MARGIT RUFFING, M.A. \\ Johannes Gutenberg-Universität Mainz, Kant-Studien-Redaktion
}

1900

BOLDT, GEORG: Protestantismens ide och Immanuel Kant: tankar i striden om tro och vetande. Helsingfors, 1900.64 S.

CathreIn, Victor: Kant, der Philosoph des Protestantismus. In: Theologisch-praktische Quartalschrift (Linz) 53, 1900, 495-507.

DÖRING, Alfred: Kants Lehre vom höchsten Gut. Eine Richtigstellung. In: Kant-Studien (Berlin) 4, 1900, 94-101.

Goujon, H[enri]: Les kantistes français: M. Liard et la métaphysique. In: Revue des Sciences ecclésiastiques (Lille) 82, 1900, Nr. 488, 97-116; Nr. 489, 217-237.

KATZER, Ernst: Die Hauptprobleme der Religionsphilosophie und ihre Lösungsversuche bei Kant. In: Neues Sächsisches Kirchenblatt (Leipzig) 7, 1900, Nr. 47, 25. Nov. 1900, Sp. 737-742; Nr. 48, 2. Dez. 1900, 753-756.

KIRCHMANN, J. H. von: Erläuterungen zu Kants Religion innerhalb der Grenzen der reinen Vernunft. Leipzig: Dürr 21900.

PAULSEN, Friedrich: Kants Verhältnis zur Metaphysik. Berlin: Reuther \& Reichard, 1900. Auch in: In: Kant-Studien (Berlin) 4, 1900, 413-447.

VAIHINGER, Hans: Kant - ein Metaphysiker? In: Philosophische Abhandlungen. Christoph Sigwart zu seinem 70. Geburtstage gewidmët. Tübingen: Mohr 1900, 133-158.

\section{1}

DENIS, Ch.: De l'influence de la philosophie de Kant et de celle de Hegel sur la critique historique appliquée aux origines chrétiennes. (Rapport présenté au "Congrès international de l'histoire des Religions" à Paris.) In: Annales de Philosophie chrétienne (Paris) 71, 1900/1901, Neue Serie: Bd. 43, 95-106.

Goujon, Henri Irénée: Kant et kantistes. Étude critique selon les principes de la métaphysique thomiste. Lille: Morel, 1901. XXIII und $331 \mathrm{~S}$.

Kugelgen, Constantin W. von: Schleiermachers Reden [über die Religion] und Kants Predigten. Zwei Aufsätze. Leipzig: Richard Wöpke, 1901. 53 S. 
1902

FONTAINE, Julien: Les infiltrations kantiennes et protestantes et le clergé français. Paris: Rétaux, 1902.

ROMUNDT, Heinrich: Kants philosophische Religionslehre - eine Frucht der gesamten Vernunftkritik. Gotha: E. F. Thienemann, 1902. IV, 96 S.

\section{3}

Guttman, Julius: Der Gottesbegriff Kants. T. 1. Phil. Diss.: Breslau, 1903. 38 S.

ROMUNDT, Heinrich: Kirchen und Kirche nach Kants philosophischer Religionslehre. Gotha: E. F. Thienemann, 1903. VIII, 199 S.

ROSENBERG, Philipp: Die Grundzüge der Kant'schen Religionsphilosophie in der «Kritik der praktischen Vernunft" und in der "Kritik der Urteilskraft". Bazin: A. Klein 1903. $50 \mathrm{~S}$. Univ. Diss.: Bern, 1903.

1904

BRAIG, Karl: Kant, der Philosoph des Protestantismus. [Mit Beziehung auf Kaftan.] In: Historisch-politische Blätter für das katholische Deutschland (München) 134, 1904, H. 2, 81-103.

GoLDSCHMIDT L[udwig]: Kant über Freiheit, Unsterblichkeit, Gott. Gemeinverständliche Würdigung. Gotha: E. F. Thienemann, 1904.

GuTBERLET, Constantin: Religion der Gottmenschlichkeit. (Zur Säkularfeier Kants.) In: Pastor bonus (Trier) 16, 1903/04, 337-347.

Kaftan, Julius: Kant, der Philosoph des Protestantismus. Rede gehalten bei der vom Berliner Zweigverein des evangelischen Bundes veranstalteten Gedächtnisfeier am 12. Februar 1904. Berlin: Reuther \& Reichhard, 1904. 34 S.

KaLWEIT, Paul: Kants Stellung zur Kirche. Schriften der Synodalkommission für ostpreußische Kirchengeschichte. H. 2. Königsberg: Ferdinand Beyer, 1904. 88 S.

LABANCA, B.*: La religione cristiana secondo Emanuele Kant. In: Nuova Parola (Roma) 1904, Nr. 3. *

LANG, Albert: Kant und die Gottesbeweise. Vortrag, gehalten auf der Generalversammlung der Görres-Gesellschaft in Straßburg am 8. Oktober 1903. In: Straßburger Diözesanblatt 23 [N.F. 6], 1904, 303-309.

PFleIDERER, Otto: Die Religionsphilosophie Kants. In: Wartburgstimmen (Eisenach und Leipzig) 1, 1904, Nr. 2, 240-250.

Pfleiderer, Otto: Was hat die Theologie des 19. Jahrhunderts von Herder und Kant gelernt? In: Protestantenblatt (Bremen / Berlin) 37, 1904, Nr. 5, 49-51; Nr. 6, 62-63. 
ReISCHLE, Max: Kant und die Theologie der Gegenwart. In: Zeitschrift für Theologie und Kirche (Tübingen) 14, 1904, 357-388.

SCHENEIDER, Walther: Die Entwicklung des Gottesbegriffes bei Immanuel Kant. In: Wissenschaftl. Beilage des Friedrich-Wilhelm-Gymnasiums zu Königsberg i. d. Neumark, 1904, 1-23.

TroeltsCH, Ernst: Das Historische in Kants Religionsphilosophie. Zugleich ein Beitrag zu den Untersuchungen über Kants Philosophie der Geschichte. In: Kant-Studien (Berlin) 9, 1904, 21-154. Auch in: Zu Kants Gedächenis. Hrsg. von Hans Vaihinger und Bruno Bauch. Berlin: Reuther \& Reichard 1904, 21-154.

WALCOTT, Gregory Dexter: Lutheran and Kantian Elements in Ritschl's Conception of God. Columbia University 1904.

WEIS, L.*: Der spekulative und der praktische Gottesbegriff Kants. In: Theologische Studien und Kritiken (Gotha) 77, 1904, 554-592.

\section{5}

OSTERmeyer, Paul Rudolf: Kants Lehre vom bösen und guten Prinzip im Vergleich mit der christlichen Lehre von der Sünde und Erlösung. Königsberg: Ostpreußische Druckerei und Verlagsanstalt, 1905. $56 \mathrm{~S}$.

RUESCH, Arnold: Freiheit, Unsterblichkeit und Gott als Ideen der praktischen Vernunft. Leipzig: Thomas, 1905. Rezensionen: K. Kessler. In: Zeitschrift für Philosophie und Philosophische Kritik (Leipzig) 154, 1914, 207-208.

SeNTroul, Charles: L'objet de la métaphysique selon Kant et selon Aristote. Louvain: Institut supérieur de philosophie, 1905. Rezensionen: K. Oesterreich. In: Kant-Studien (Berlin) 11, 1906, 466-469.

Sulze, Emil: Luther und Kant. In: Protestantische Monatshefte (Berlin) 9, 1905, 161-172.

THILO, Ch[ristfried] A[lbert]: Kants Religionsphilosophie. Langensalza: Hermann Beyer \& Söhne, 1905. VI, 65 S. [Religionsphilosophie in Einzeldarstellungen, H. 1.]

\section{6}

FITTBOGen, Gottfried: Kants Glaube. Versuch einer neuen Deutung. In: Protestantische Monatshefte (Leipzig) 1906, 102-114; 127-140.

Glossenr, M.*: Crónica alemana. Kant, el filósofo del protestantismo. In: Cultura EspaZola (Madrid) 3, 1906, 868-873.

GutTManN, Julius: Kants Gottesbegriff in seiner positiven Entwicklung, 1906. 104 S. [KSEH Nr. 1; Nachdruck: Würzburg: Journalfranz 1978.]

HoEKSTRA, Tjeerd: Immanente Kritik zur Kantischen Religionsphilosophie. Phil. Diss.: Heidelberg, 1906. $93 \mathrm{~S}$.

OESTERREICH, Konstantin: Kant und die Metaphysik, 1906. [KSEH Nr. 2; Nachdruck: Würzburg: Journalfranz 1978.] Zugleich Phil. Diss.: Berlin, 1905. 42 S. 
Oetuli, Samuel: Das Urteil Kants über die alttestamentliche Religion. Festschrift der Universität Greifswald ausgegeben zum Rektoratswechsel am 15. Mai 1906. Greifswald, 1906. 33 S.

PACHAlY, Erich: J. G. H. Feders Erkenntnistheorie und Metaphysik in ihrer Stellung zum Kritizismus Kants. Phil. Diss.: Erlangen, 1906. 68 S.

\section{7}

ARNOLDT, Emil: Über Kants Idee vom höchsten Gut. Habilitationsvorlesung gehalten am 13 März 1874 an der Königl. Albertus-Universität zu Königsberg. In: Arnoldt, Emil: Gesammelte Schriften 1. Berlin 1907, 196-228.

FITTBOGEN, Gottfried: Kants Lehre vom radikal Bösen. In: Kant-Studien (Berlin) 12, 1907, 303-360.

Glossner [Gloszner], M.*: Kant der Philosoph des Protestantismus. In: Jahrbuch für Philosophie und spekulative Theologie (Paderborn) 22, 1907, 1-23.

LÖsment,. Max: Zur Religionsphilosophie Kants. Phil. Diss.: Königsberg, 1907. 46 S.

Pringle-Pattison, A[ndrew] Seth: The Philosophical Radicals, and Other Essays. With chapters on the Philosophy of Religion in Kant and Hegel. Edinburgh/London: William Blackwood \& Sons, 1907. X, 336 S. [Repr.: New York: Burt Franklin, 1967.]

ARNOLDT, Emil: Beiträge zu dem Material der Geschichte von Kant's Leben und Schriftstellertäthigkeit in Bezug auf seine "Religionslehre» und seinen Conflict mit der Preussischen Regierung. In: Arnoldt, Emil: Gesammelte Schriften, Bd. IV. Berlin: Verlag von Bruno Cassirer, 1908, 1-207.

BaUCH, Bruno: Kants Prinzip der sittlichen Freiheit und die Religion. In: Freie bayerische Schulzeitung (Würzburg) 9, 1908, 280-282.

BORMANN Walter: Steuer der Wahrheit zu Kant's «Vorlesungen über Metaphysik». In: Psychische Studien (Leipzig) 35, 1908, 289-296.

Franke, Hermann: Kants Stellung zu den Gottesbeweisen im Zusammenhange mit der Entwicklung seines kritischen Systems. Phil. Diss.: Breslau, 1908. 164 S.

Gebert, Karl: Kants autonome Ethik und der fortschrittliche Katholizismus I, II, Schluß. In: Das zwanzigste Jahrhundert. Organ für fortschrittlichen Katholizismus (München) 8, 1908, Nr. 22, 253-256; Nr. 23, 266-269; Nr. 24, 280-281.

GlossneR, M.*: Vorstoß der «Kantstudien» gegen die katholische Wissenschaft. In: Jahrbuch für Philosophie und spekulative Theologie (Paderborn) 23, 1908, 38-44.

SENDLER, Alexander: Die metaphysischen Grundlagen mathematischer Naturbetrachtung bei Kant und Fries. Phil. Diss.: Jena, 1908. VIII, 71 S. 


\section{9}

ARNOLDT, Emil: Das Manuskript der "Religion innerhalb der Grenzen der bloßen Vernunftw. In: Arnoldt, Emil: Gesammelte Schriften, Bd. VI. Berlin: Verlag von Bruno Cassirer 1909, 41-103. [zuerst AM 34/1897].

JORDAN, Bruno: Kants Stellung zur Metaphysik in den vorkritischen Schriften. Leipzig: Quelle \& Meyer 1909. VI, 86 S. [Phil. Diss.: Jena, 1909. 58 S.]

OTTO, Rudolf: Kantisch-Fries'sche Religionsphilosophie und ihre Anwendung auf die Theologie. Zur Einleitung in die Glaubenslehre für Studenten der Theologie. Tübingen: J. C. B. Mohr, 1909. XIV, 200 S.

WEYHING, Emil: Kants Gottesbegriff in den drei Kritiken. Ein Beitrag zu seiner Ideenlehre. Phil. Diss.: Gießen, 1909. 67 S.

COHEN, Hermann: Kants Begründung der Ethik nebst ihren Anwendungen auf Recht, Religion und Geschichte. Zweite verbesserte und erweiterte Auflage Berlin: Bruno Cassirer, 1910. XX, 557 S.

DREBLER, M[ax] Christoph: Liegt in Kants religionsphilosophischen Anschauungen der Keim zur Weiterentwicklung nach dem Schleiermacherschen Prinzip hin vom Ursprung des religiösen Bewußtseins? Hamburg: Hermann 1910. Phil. Diss.: Erlangen, 1910. 56 S.

PlaTE, Hugo: Die Stellung Melanchthons und Gerhards zur Kantischen Kritik der Möglichkeit einer natürlichen Gotteserkenntnis. Phil. Diss.: Göttingen, 1910. 48 S.

1911

CoIGNET, Clarisse: De Kant à Bergson, réconciliation de la religion et de la science dans un spiritualisme nouveau. Paris: Alcan, 1911. 157 S.

GisLer, A.: Kant und das Dasein Gottes. In: Schweizerische Rundschau (Einsiedeln) 11, 1911, 335-341.

SCHмITT,*: Warum muß der Religionslehrer auf Prima zum erkenntnistheoretischen Kritizismus Kants Stellung nehmen und wie kann das geschehen? In: Monatsblätter für den katholischen Religionsunterricht an höheren Lehranstalten (Köln) 7, 1911, Nr. 7 , 193-204; Nr. 8, 225-235.

Szuman, Jan Nepomuk: Poglad krytyczny na metafizyke Kanta [Kritischer Blick auf die Metaphysik Kants]. Poznan 1911.

WheEler, Charles Kirkland: Critique of Pure Kant or A Real Realism vs. A Fictitious Idealism in a word, The Bubble and Monstrosity of the Kantian Metaphysic. Boston: The Arakelyan Press, 1911. 298 S. 
BEERMANN,*: Kant und das Judentum. In: Zeitschrift für Religionspsychologie (Leipzig) 5, 1912, 295-299.

DinDINGER, J.*: Die Metaphysik von Welt, Seele und Gott beim hl. Thomas und bei Kant und ihre Stellung zum katholischen Dogma. In: Theologie und Glaube (Paderborn) 4, $1912,544-569$.

DRIESSEN, Hubertus: God en godsdienst bij Emmanuel Kant. Utrecht: Wed J. R. van Rossum's / Hertogenbosch: C. N. Teulings, 1912. 238 S. [Uitgaven v.d. apologetische vereeniging "Petrus Canisius»; Nr. 51.]

LeHMaN, Hugo: Das Apriori der Geistesbildung und dessen Betonung als Andacht. Eine Weirerführung des kantischen Glaubens sirtlicher Auronomie. Phil. Diss.: Jena, 1912. VI, 58 S. [Aus: Zeitschrift für Religionspsycholologie Bd. 6.]

Sentroul, Charles: La philosophie religieuse de Kant. Paris: Le Coffre; Bruxelles: Coomans, 1912. 99 S. Auch in: Revue des sciences philosophiques et théologiques 4, 1910, 49-81, 233-256.

ZENOFF, Krestu: Kants Religionslehre. Crimmitschau: R. Raab 1912. 87 S. [Univ. Diss.: Bern 1911.]

1913

BECKMANN, Kurt: Berührungen Johann Joachim Spaldings mit Immanuel Kant in der Fassung seines Religionsbegriffes. Phil. Diss.: Göttingen, 1913. 62 S.

Bund, Hugo: Kant als Philosoph des Katholizismus. Berlin: Carl Hause, 1913. 357 S.

Charles, Pierre: La métaphysique du kantisme. In: Revue de Philosophie (Paris) 13, 1913, Nr. 22, 113-136.

Kopp, Cl.*: Die erste katholische Kritik an Kants Grundlegung zur Metaphysik der Sitten. In: Philosophisches Jahrbuch der Görres-Gesellschaft (Fulda) 26, 1913, 170-177.

Petras, Otto: Der Begriff des Bösen in Kants Kritizismus und seine Bedeutung für die Theologie. Leipzig: Hinrichs, 1913. Zugl. Univ. Diss.: Breslau (Ev. Theol.) 1913. 41 S. [unvollständig].

RTTTER, Karl Bernhard: Über den Ursprung einer kritischen Religionsphilosophie in Kants “Kritik der reinen Vernunft». Univ. Diss.: Erlangen, 1913. $80 \mathrm{~S}$.

\section{4}

FICHTE, Johann Gottlieb: Über Gott und Unsterblichkeit. Aus einer Kollegnachschrift von 1795 mitgeteilt von E. Bergmann. Berlin 1914. [KSEH Nr. 33; Nachdruck: Würzburg: Journalfranz 1978.]

KATZER, Ernst: Religion und Fiktion. Eine Kantstudie. In: Zeitschrift für Theologie und Kirche (Tübingen) 24, 1914, 261-284. 
SCHMITT, Robert - JUNGLAS, *: Kant. Der Agnostizismus. In: Monatsblätter für den katholischen Religionsunterricht an höheren Schulen (Köln) 15, 1914; Teil I, II (Schmitt): 161-170; Teil III (Junglas): 193-196.

SEITZ, Anton: Kant und die Gottesbeweise. In: Theologie und Glaube (Paderborn) 6, 1914, 182-191.

\section{5}

LEISEGANG, Hans: Über die Behandlung des scholastischen Satzes: «Quodlibet ens est unum, verum, bonum seu perfectum", und seine Bedeutung in Kants Kritik der reinen Vernunft. In: Kant-Studien (Berlin) 20, 1915, 403-421.

PaQuier, Jules: Le Protestantisme allemand. Luther, Kant, Nietzsche. Paris: Bloud \& Gay, 1915. 144 S.

THOME, J.*: Kants Stellung zu den Gottesbeweisen in seiner vorkritischen Periode. In: Philosophisches Jahrbuch der Görres-Gesellschaft (Fulda) 28, 1915, 380-396.

\section{6}

KOPPERMAN, Ernst: Der Offenbarungsbegriff in der Religionsphilosophie Kants, Fichtes, Fries'. Phil. Diss.: Erlangen, 1916. IX, 84 S.

KRALIK, Richard von: Kant als Philosoph des Katholizismus. In: Kralik, Richard von: Vom Weltkrieg zum Weltbund. Innsbruck 1916, 416-420.

\section{7}

HEINZE, Max: Vorlesungen Kants über Metaphysik aus drei Semestern. Leipzig: S. Hirzel, 1917 ['1894]. [Abhandlungen der philologisch-historischen Classe der KöniglichSächsischen Gesellschaft der Wissenschaften.]

JONQUIERE, Georg: Die grundsärzliche Unannehmbarkeit der transzendentalen Philosophie Immanuel Kants. Das "Primat" der Kritik der praktischen Vernunft vor der Kritik der reinen Vernunft. Das Verhältnis Kants zur Naturwissenschaft, zur Theologie und zur Kirche. Problematische Ausblicke. Bern: A Francke, 1917.

LIEBERT, Arthur: Zur Psychologie der Metaphysik. In: Kant-Studien (Berlin) 21, 1917, $42-$ 54.

\section{8}

KATZER, [Ernst]: Kant und die jüdische Religion. In: Neues sächsisches Kirchenblatt (Leipzg) 25, 1918, Nr. 19, 233-239.

LAMBERT, Johann Heinrich: Über die Methode, die Metaphysik, Theologie und Moral richtiger zu beweisen. Aus dem Manuskript herausgegeben von K. Bopp. Berlin 1918. [KSEH Nr. 42; Nachdruck: Vaduz: Topos 1978.] 
VERWEYEN, Johannes M.: Zur Logik der Gottesbeweise. In: Kant-Studien (Berlin) 22, 1918, 302-328.

WIETRZYCHOWSKI, Bronislaus: Kants Religionsphilosophie und der englische Deismus. Phil. Diss.: Breslau, 1918. IX, 124 S.

ZINBER, ${ }^{*}$ : Kant und Luther. Konferenzvortrag. In: Sächsisches Kirchen- und Schulblatt (Dresden), 1918, Nr. 35, 30. August 1918, Sp. 513-518; Nr. 36, 6. Sept. 1918, Sp. 529-532; Nr. 37, 13. Sept. 1918, Sp. 537-541.

Delbos, Victor: Les facteurs kantiens de la philosophie allemande au commencement du $\mathrm{XIX}^{\circ}$ siècle. [I. Kant et la métaphysique; II. Le problème de la chose en soi.] In: Revue de Métaphysique et de Morale (Paris) 26, 1919, 569-593.

HeRBers, [Gottfried]: Kant, Schleiermacher, Schopenhauer, Nietsche [sic!], Haeckel in ihrer Bedeutung für Weltanschauung und Religion. 4 Vorträge. Duisburg: Selbstverlag, ${ }^{2} 1919.64$ S.

1920

BAUMGARTNER, Matthias: Kant und die Gottesbeweise. In: Ehrengabe deutscher Wissenschaft dargeboten von katholischen Gelehrten. Hrsg. von Franz Fessler und Johann G. zu Sachsen. Freiburg i. Br.: Herder, 1920, 35-51.

Bergmann, Gregorio: El libre arbitrio y el determinismo en la metafísica. El ejemplo de Kant. In: Revista de la Universidad Nacional de Córdoba, Arg. 7, Nr. 1, 1920, 161-177.

BOETTE, Werner: Kants Religion. Langensalza: Beyer \& Söhne, 1920. $123 \mathrm{~S}$.

DENTICE DI ACCADIA, Cecilia: Il razionalismo religioso di E. Kant. Bari: Laterza, 1920.

Ewald, Oscar: Welche wirklichen Fortschritte hat die Metaphysik seit Hegels und Herbarts Zeiten in Deutschland gemacht? Berlin: Reuther \& Reichard, 1920. 67 S. [KSEH Nr. 53; Nachdruck: Vaduz: Topos 1978.]

INAUEN, Andreas: Kants Gottesbegriff. In: Philosophisches Jahrbuch der GörresGesellschaft (Fulda) 33, 1920, 209-232.

REMMY, Richard: Wird durch die Als-Ob-Betrachtung bei Kant die Realität Gottes in Frage gestellt? Eine Auseinandersetzung mit Vaihingers ,Philosophie des Als-Ob'. Univ. Diss.: Erlangen, 1920. $48 \mathrm{~S}$.

OTTO, Rudolf: Kantisch-Friessche Religionsphilosophie und ihre Anwendung auf die Theologie. Tübingen: J. C. B. Mohr, ${ }^{2} 1921$ ['1909].

SCHOLZ, Heinrich: Die Religionsphilosophie des Als-Ob. Eine Nachprüfung Kants und des idealistischen Positivismus. Leipzig: Meiner, 1921. $160 \mathrm{~S}$. 
Deneffe, August: Kant und die katholische Wahrheit. Freiburg i. Br.: Herder \& Co., 1922. $\mathrm{X}, 200 \mathrm{~S}$.

KIEFL, Franz Xaver: Kants kritischer Idealismus und das Christentum. In: Katholische Weltanschauung und modernes Denken. Gesammelte Essays über die Hauptstationen der neueren Philosophie. 2. und 3. Aufl. Regensburg: Manz 1922, 82-106.

SCHREIBER, Christian: Kant und die Gottesbeweise. Philosophische Gedankengänge. Dresden: Saxoma-Buchdruckerei, 1922.62 S.

TiluICH, Paul: Die Überwindung des Religionsbegriffs in der Religionsphilosophie. In: Kant-Studien (Berlin) 27, 1922, 446-469.

GeYSER, Joseph: Einige Hauptprobleme der Metaphysik mit besonderer Bezugnahme auf die Kritik Kants. Freiburg i. B.: Herder, 1923. 167 S.

JANSEN, Bernhard: Kant, der Religionsphilosoph der Aufklärung. In: Stimmen der Zeit (Freiburg) 104, 1923, 1-11.

MARECHAL, Joseph: Le point de départ de la métaphysique. Leçons sur le développement historique et théorique du problème de la connaissance. Bd. III: La Critique de Kant. (Museum Lessianum - Section philosophique, Nr. 5). Bruges: C. Beyaert, 1923 [21942].

RoTTA, Paolo: Il problema dell'origine del male in Platone e in Kant. In: Rivista di filosofia neo-scolastica (Milano) 15, 1923, 1-22.

\section{4}

BORNHAUSEN, Karl: Die Religion der Vernunft. In: Kant-Studien (Berlin) 29, 1924, $377-$ 385.

Bornhausen, Karl: Der Primat der praktischen Vernunft in der Religionsphilosophie. Zur 200. Wiederkehr des Geburtstages I. Kants. In: Zeitschrift für Theologie und Kirche (Tübingen) 5, 1924, H. 2, 85-103.

BRUHN, Wilhelm: Kant im Religionsunterricht. In: Zeitschrift für den evangelischen Religionsunterricht (Berlin) 35, 1924, Nr. 1, 2-10.

DeNTICE Di ACCADIA, Cecilia: Il problema del male nell'etica e nella filosofia religiosa di Kant. In: Giornale critico della filosofia italiana (Firenze) 5, 1924, 262-268.

DOERnE, Martin: Ist Kant der Philosoph des Protestantismus? In: Allgemeine EvangelischLutherische Kirchenzeitung (Leipzig) 57, 1924, 738-743, 755-757; 778-779; 794-799; 818-821; 835-839.

GOEDECKEMEYER, Albert: Immanuel Kants Weg zur Metaphysik. In: Beiträge zur Philosophie des deutschen Idealismus 3. Bd. Erfurt: Verlag Kurt Stenger, 1924, Nr. 2, 50-64. 
Heimsoeth, Heinz: Metaphysische Motive in der Ausbildung des kritischen Idealismus. In: Kant-Studien (Berlin) 29, 1924, 121-159.

JANSEN, Bernhard: Structura philosophiae religionis Kantianae. In: Gregorianum (Roma) 5 , 1924, 46-57.

KNITTERMeYER, Hinrich: Kant und der Protestantismus der Gegenwart. In: Marx - Kant Kirche. Verhandlungen des Bundes für Gegenwartschristentum 1924, 60-78.

MESSER, August: Die sittlich-religiöse Grundlage von Kants Philosophie. In: Unsere Welt. Illustrirte Zeitschrift für Naturwissenschaft und Weltanschauung (Godesberg b. Bonn) 16 [Jg. 15], 1924, 74-78.

PADOVANI, Umberto: La religione nei limiti della ragione. In: Immanuel Kant (1724-1924). Hrsg. von A. Gemelli. Milano 1924, 153-186.

Rossi, Guido: Il problema dell'esistenza di Dio nelle varie fasi del pensiero Kantiano. In: Immanuel Kant (1724-1924). Hrsg. von A. Gemelli. Milano 1924, 187-281.

RUST, Hans: Kants Verhältnis zum Protestantismus. In: Hochschulwissen (Warnsdorf) 1, 1924, Heft 4, 157-162.

RuST, Hans: Kant und Kalvin. In: Immanuel Kant. Festschrift zur zweiten Jahrhundertfeier seines Geburtstages. Hrsg. von der Albertus-Universität zu Königsberg i. Pr. Leipzig 1924, 129-149.

SCHULZE, Martin: Das «radikale Böse" und die "Wiedergeburt». In: Immanuel Kant. Festschrift zur zweiten Jahrhundertfeier seines Geburtstages. Hrsg. von der AlbertusUniversität zu Königsberg i. Pr. Leipzig 1924, 203-238. [Auch als Sonderdruck: Leipzig, Dieterichsche Verlagsbuchhandlung.]

SCOTT, John Waugh: Kant on the Moral Life. An exposition of Kant's "Grundlegung». London: A. \& C. Black, 1924. VIII, 182 S.

STEPHAN, Horst: Kant und die Religion. In: Kant-Studien (Berlin) 29, 1924, 207-232.

VORLÄNDER, Karl: Das Verhältnis von Religion und Naturwissenschaft bei Kant. In: Unsere Welt. Illustrirte Monatsschrift für Naturwissenschaft und Weltanschauung (Godesberg b. Bonn) 16 [Jg. 15], 1924, 78-80.

Wobbermin, Georg: Luther, Kant, Schleiermacher und die Aufgabe der heutigen Theologie. In: Zeitschrift für Theologie und Kirche (Tübingen) N. F. 5, 1924, H. 2, 104-120.

WUNDT, Max: Kant, der Metaphysiker. Berlin 1924.

WUNDT, Max: Kant als Metaphysiker. Ein Beitrag zur Geschichte der deutschen Philosophie im 18. Jahrhundert. Stuttgart: Ferdinand Enke, 1924. VIII und 554 S.

BauCH, Bruno: Das Problem der Religionsphilosophie im System des transzendentalen Idealismus. In: Zeitschrift für Theologie und Kirche (Tübingen) N. F. 6, 1925, 1-28.

BETH, Karl: Das Erlebnis in Religion und Magie. In: Kant-Srudien (Berlin) 30, 1925, 381-408. 
BRUHN, Wilhelm: Die Kantliteratur des Jubiläumsjahres und ihr religionsphilosophischer Ertrag. In: Zeitschrift für Theologie und Kirche (Tübingen) [Neue Folge] 6, 1925, 137 157.

DilTheY, Wilhelm: Der Streit Kants mit der Zensur über das Recht freier Religionsforschung [1900]. In: Dilthey, Wilhelm: Gesammelte Schriften. Bd. 4. Leipzig/Berlin 1925, 285-309.

ENGERT, Joseph: Kant und seine Kritik der Gottesbeweise. In: Pharus. Katholische Monatsschrift für Orientierung in der gesamten Pädagogik (Donauwörth) 16, 1925, 593610, 684-695. Auch in: Engert, Joseph: Studien zur theologischen Erkenntnislehre. Regensburg: Manz, 1926, 128-163.

GarbeIS, Franz W: Das Problem des Bewußtseins in der Philosophie Kants. Eine erkenntnistheoretische Untersuchung der Grundlagen des Denkens und des Seins. Wien / Leipzig: Wilhelm Braumüller, 1925. $152 \mathrm{~S}$.

Hoffman, Philipp: Die psychischen Grundlagen der Metaphysik Kants. Phil. Diss.: Wien, 1925. [Typoskript]

INAUEN, Andreas: Kantische und scholastische Einschätzung der natürlichen Gotteserkenntnis. Innsbruck: Felizian Rauch, 1925. 92 S. [Philosophie und Grenzwissenschaften, I, 5.]

LENZ, Joseph: Kantianismus und Katholizismus. In: Pastor bonus (Trier) 36, 1925, 40-58.

MESSER, August: Glaube und Wissen bei Kant und im neueren Protestantismus. In: Philosophie und Leben (Osterwieck/Harz) 1, 1925, Heft 1, 2-6.

SCHUlzE, Martin: Die Idee des Reiches Gottes bei Kant. Königsberg: Gräfe \& Unzer, 1925. $35 \mathrm{~S}$.

SWITALSKI, [Bronislaus] W[ladislaus]: Kant und der Katholizismus. Vortrag, gehalten auf der Heidelberger Tagung der Görres-Gesellschaft am 29. September 1924. Münster. Münster i. W.: Aschendorff 1925, 30 S.

VAlensin, Auguste: À travers la métaphysique. [I. Kantiana: Le criticisme kantien. La théorie d'expérience d'après Kant. Déduction du Criticisme.] Paris 1925.

BIERNATZKI, Reinhart: Kant und die höchsten Güter der Religion nach Paul Deussen. Mit einem Deussen-Bildnis und einer Vorlesungsankündigung aus seiner Feder. Hamburg: Boysen 1926. XVI und 94 S. [Zugleich Phil. Diss. Königsberg: Kants Erkenntnislehre in ihrem Zusammenhang mit den Hauptwerten der Religion nach Paul Deussen.]

BRAUBACH, Bernhard: Kant als Schöpfer einer neuen Metaphysik. Eine Darstellung und Würdigung der Grundgedanken des Buches von Max Wundt "Kant als Metaphysiker». In: Philosophisches Jahrbuch der Görres-Gesellschaft (Fulda) 36 1926, 419-434.

DEMPF, Alois: Das Unendliche in der mittelalterlichen Metaphysik und in der kantischen Dialektik. Münster: Aschendorff, 1926. 91 S. [Veröffentlichungen des katholischen Instituts für Philosophie. Albertus-Magnus-Akademie zu Köln, II, 1.] 
DYROFF, Adolf: Kant und die Gottesbeweise. In: Akademische Bonifatius-Korrespondenz (Paderborn) 39, 1926, 18-26.

KASZEMEK, Johannes: Kant und die Forderungen des Preuß. Lehrer-Vereins zum Religionsunterricht vom 30. und 31. Mai 1919. In: Preußische Lehrer-Zeitung, 1926, Nr. 41.

SCHLICK, Moritz: Erleben, Erkennen, Metaphysik. In: Kant-Studien (Berlin) 31, 1926, 146 158.

WEBB, Clement C[harles] J[ulian]: Kant's Philosophy of Religion. Oxford, 1926. 218 S. [Repr. New York, 1970.]

DRIESCH, Hans: Von Descartes bis Kant. In: Metaphysik der Natur. [Handbuch der Philosophie, Abt. 2, b.] München, 1927, 29-49.

HASENFUB, Josef: Die Grundlagen der Religion bei Kant, dargestellt und kritisch gewürdigt. Würzburg: C. J. Becker, 1927. XVI, 184 S. [Abhandlungen zur Philosophie und Psychologie der Religion, H. 12/13.]

IMLE, Fanny: Friedrich von Schlegels Entwicklung von Kant zum Katholizismus. Paderborn: Ferdinand Schöningh, 1927. VI, 287 S.

RENDA, Antonio: Il criticismo. Fondamenti etico-religiosi. Palermo: Sandron, 1927. 422 S.

REINHARD, Walter: Über das Verhältnis von Sittlichkeit und Religion bei Kant unter besonderer Berücksichtigung des Opus postumum und der Vorlesung über Ethik. Bern: P. Haupt 1927. 47 S. [Univ. Diss: Bern, 1927.]

SCHMalenbaCH, Hermann: Das Metaphysische in Kant. In: Pädagogische Warte (Osterwieck) 34, 1927, Heft 12, 621-627.

SCHULzE, Martin: Kants Religion innerhalb der Grenzen der bloßen Vernunft erklärt. Königsberg: Gräfe \& Unzer, 1927. 199 S.

1928

JaNSEN, Bernhard: Der ideelle Ort Gottes im System des Kritizismus. In: Stimmen der Zeit $114,1927 / 28,14-31$.

JANSEN, Bernhard: Der Sinn der Religion nach Kant. In: Stimmen der Zeit 114, 1927/28, 440-450.

KESSELER, Kurt: Der Ertrag der Kantischen Religionsphilosophie. In: Monatsblätter für den evangelischen Religionsunterricht (Göttingen) 21, 1928, 6-18.

KRUMME, Josef: Kants ontologischer Gottesbeweis in seiner Schrift: ,Der einzig mögliche Beweisgrund zu einer Demonstration des Daseins Gottes'. Phil. Diss.: Münster, 1928. $42 \mathrm{~S}$.

MartinetTi, Piero: La religione secondo E. Kant. In: Rivista di Filosofia (Bologna) 19, 1928, Nr. 1, 1-19. 
Morelle, F*: Les idées religieuses de Kant en 1755-1760. In: Revue Néo-Scolastique de Philosophie (Louvain) 30, 1928, 275-315.

Platenius, Otto: Schellings Fortführung der Lehre Kants vom Bösen. Ein Beitrag zur Religionsphilosophie des deutschen Idealismus. Phil. Diss.: Erlangen, 1928. $72 \mathrm{~S}$.

RusT, Hans: Kant und das Erbe des Protestantismus. Ein Beitrag zu der Frage nach dem Verhältnis von Idealismus und Christenheit. Gotha: Leopold Klotz, 1928. 123 S.

ScHMIDT, Hans Wilhelm: Das Reich Gottes bei Kant. In: Christentum und Wissenschaft (Braunschweig) 4, 1928, Nr. 3, 247-257.

WOBBERMIN, [Georg]: Religionsphilosophie als theologische Aufgabe. In: Kant-Studien (Berlin) 33, 1928, 200-218.

ZIEHEN, Theodor: Religionsphilosophie Kants. In: Ziehen, Theodor: Grundlagen der Religionsphilosophie. Acht Rundfunk-Vorträge. Leipzig: Meiner, 1928, 102-120.

\section{9}

BAUMBACH, Rudolf: Das Irrationale in Kants Religionsphilosophie. Univ. Diss. [Theol.]: Heidelberg, 1929.66 S.

England, F. E.*: Kant's Conception of God: A Critical Exposition of Its Metaphysical Development together with a Translation of the Nova Dilucidatio. London: George Allen \& Unwin Ltd., 1929. 256 S. [Phil. Diss.: London 1928; Reprint New York 1968.]

FranK, S.*: Zur Metaphysik der Seele. (Das Problem der philosophischen Anthropologie.) In: Kant-Studien (Berlin) 34, 1929, 351-373.

Hasenfub, Josef: Die Grundlagen der Religion bei Kant. (Dargestellt und kritisch gewürdigt.) Theol. Diss.: Würzburg, 1929. XVI, $183 \mathrm{~S}$. [Auch als: Abhandlungen zur Philosophie und Psychologie der Religion H. 12/13, Würzburg 1927.]

HeIDEGGer, Martin: Kant und das Problem der Metaphysik. Bonn: Cohen 1929. XII, 236 S.

HEIMSOETH, Heinz: Kant und die Deutsche Schulmetaphysik des 18. Jahrhunderts. In: Heimsoeth, Heinz: Metaphysik der Neuzeit. [Handbuch der Philosophie, Abt. 1, f.] München, 1929, 79-104.

Herrigel, Eugen: Die metaphysische Form. Eine Auseinandersetzung mit Kant. 1. Halbband: Der Mundus sensibilis, Tübingen, J. C. B. Mohr, 1929.

JANSEN, Bernhard [Bernardus]: Die Religionsphilosophie Kants. Geschichtlich dargestellt und kritisch-systematisch gewürdigt. Berlin: Dümmler, 1929.

MESSER, August: Kommentar zu Kants ethischen und religionsphilosophischen Hauptschriften [Grundlegung zur Metaphysik der Sitten, Kritik der praktischen Vernunft, Religion innerhalb der Grenzen der bloßen Vernunft]. Leipzig 1929. [Wissen und Forschen 22.] Rezensionen: H. Hegenwald. In: Grundwissenschaft (Leipzig) 11, 1932, 266-267.

MONTALTO, Francesco: Religione e filosofia in Aristotele, S. Tommaso ed E. Kant. In: Atti VII Congresso naz. di Filosofia, Roma 1929. Milano: Bestetti e Tuminelli, 1929. Auch in: Giornale critico della Filosofia Italiana (Firenze) 10, 1929, 372-390. 
MORElle, F.*: Les idées religieuses de Kant en 1755-1760 (suite et fin). In: Revue NéoScolastique de Philosophie (Louvain) 31, 1929, 280-308.

SCHmalenbach, Herman: Kants Religion. Berlin: Junker \& Dünnhaupt, 1929. 133 S. [Sonderhefte der Deutschen Philosophischen Gesellschaft 1.]

AlthauS, Paul: Staat und Reich Gottes. In: Kant-Studien (Berlin) 35, 1930, 114-118.

BARTH, H[einrich]: Heidegger und Kant. Zu Martin Heideggers Buch über "Kant und das Problem der Metaphysik». In: Theologische Blätter (Leipzig) 40, 1930, 139-146.

FUETSCHER, Lorenz: Die Frage nach der Möglichkeit der Metaphysik bei Kant und in der Scholastik. In: Zeitschrift für katholische Theologie (Innsbruck) 54, 1930, 493517.

JANSEN, Bernhard: Augustinus und Kant. Um Methode und Inhalt der Metaphysik. In: Philosophisches Jahrbuch der Görres-Gesellschaft (Fulda) 43, 1930, 18-40.

NINK, Caspar: Zum ontologischen Gottesbeweise bei Kant. In: Philosophia perennis. Festgabe J. Geyser zum 60. Geburtstag. Hrsg. von Fritz-Joachim von Rintenlen. Frankfurt a. M. 1930, 309-321.

SCHWITZKE, Heinz: Die Beziehungen zwischen Aesthetik und Metaphysik in der deutschen Philosophie von Kant. Phil. Diss.: Berlin, 1930. Charlottenburg: Gebr. Hoffmann, $1930.93 \mathrm{~S}$.

SCIAKY, Isacco: Religioni positive e religione razionale pura in Kant. In: Civiltà moderna (Firenze) 20, 1930, Nr. 6, 1108-1123.

DAL MONTE, F.*: Il concetto kantiano di Dio secondo il Fazio-Allmayer. In: Ricerche Religiose (Roma) 1931, Nr. 2, 180-181. [Zu: Fazio-Allmayer, Vito: Immanenza. In: Giornale critio della filosofia italiana $1930, \mathrm{Nr}$. 6.]

CASSIRER, Ernst: Kant und das Problem der Metaphysik. Bemerkungen zu Martin Heideggers Kant-Interpretation. In: Kant-Studien (Berlin) 36, 1931, 1-26.

DRÜKE, Leo: Die Stellung Kants zur christlichen Gottesverehrung. Dargestellt und kritisch gewürdigt unter besonderer Berücksichtigung des Gebetes. Kath. theol. Diss.: Münster, $1931.51 \mathrm{~S}$.

KotsuKa, Shinichiro: Die Gottesbeweise in der Philosophie Kants. Borna / Leipzig: Noske 1931. Phil. Diss.: Berlin, 1931. 105 S.

SCHÄFFER, Arnold: Untersuchungen zur Religionsphilosophie Kants. Phil. Diss.: Gießen, 1931. $71 \mathrm{~S}$.

SNETHLAGE, J[acob] L[eonard]: De godsdienstphilosophie van Immanuel Kant. Assen: De Wachttoren, 1931. 251 S. ["Het handboek", bibliotheek van wetenschappelijke geschriften over den godsdienst.] 
SwEAZEY, George: Wie ist Religion überhaupt möglich? Nach den Grundsätzen des Kantischen Idealismus, gemäß den Schriften: ,Die Kritik der praktischen Vernunft', 2. Teil, und ,Die Religion innerhalb der Grenzen der bloßen Vernunft'. Phil. Diss.: Berlin, $1931.118 \mathrm{~S}$.

\section{2}

GREYSER, J.*: Alguns problemas capitais da Metafisica com especial referLncia a Kant. Übersetzt von L. F. dos Santos. Coimbra: Imprensa da Universidade, 1932.

RÜFNER, Vinzenz: Die transzendentale Fragestellung als metaphysisches Problem. Studie zur Metaphysik des deutschen Idealismus. Phil. Habil.-Schrift. Würzburg 1932. VIII, 120 S. [Forschungen zur neueren Philosophie und ihrer Geschichte 4.]

SCHILling, Jakob: Die Auffassungen Kants und des hl. Thomas von Aquin von der Religion. Würzburg: Verlag C. J. Becker Universitätsdruckerei, 1932 [Zugleich Univ. Diss.: Bonn, 1931]. XII und 241 S. [Abhandlungen zur Philosophie und Psychologie der Religion, H. 27/28.]

\section{3}

FEDI, R.*: L'esistenza di Dio nella filosofia Kantiana precritica. In: Il idealismo realistico (Roma) 1933. *

JANSEN, Bernhard: Die Kopernikanische Wende in der Metaphysik: Kant und Thomas. In: Jansen, Bernhard: Aufstiege zur Metaphysik heute und ehedem. Freiburg i. B. 1933, 341-364.

\section{4}

BAUKE, [Hans Konrad]: Die Dialektik des intelligibelen und des empirischen Charakters als Grundphänomen der Religionsphilosophie Kants. Phil. Diss.: Breslau, 1934, 136 S.

JANSEN, Bern[h]ard: La philosophie religieuse de Kant. Aus dem Deutschen übersetzt von P. Chaillet. Paris: Vrin, 1934. Rezensionen: J. M. Le Blond. In: Revue Pratique d'Apologétique 1935, 677-681.

Pelloux, Luigi: Il problema del male nella dottrina di Kant. In: Rivista di Filosofia NeoScolastica (Milano) 26, 1934, 402-422.

\section{5}

DYROFF, Adolf: Über Reiners Bearbeitung der Kantschen Schrift Die Religion innerhalb der Grenzen der bloßen Vernunft. In: Kant-Studien (Berlin) 40, 1935, 270-276.

EYSELE, Charles: Les facteurs psychologiques de la philosophie religieuse de Kant. In: Revue de Philosophie (Paris) 6, 1935, 419-435.

JOLIVET, Régis: Intuition intellectuelle et le problème de la métaphysique. Kant. In. Archives de Philosophie (Paris) 11, 1934/35, 200-204. 
LE Blond, J[ean]-M[arie]: La philosophie religieuse de Kant. In: Revue Apologétique (Paris) 60, 1935, 677-681.

LUPORINI, C[esare]: Critica e metafisica nella filosofia kantiana. In: Rendiconti della reale Accademia Nazionale dei Lincei. Classe di Scienze Morali, Storiche, e Filologiche (Roma) 11, 1935, 87-115.

ManorR, H.* du: La philosophie religieuse de Kant. In: Nouvelle Revue Théologique (Paris) 62, 1935, 21-34.

NoBiLE, Emilia: Difesa della metafisica Kantiana in una lettera inedita di Pasquale D'Ercole. In: Logos (Napoli), 1935, Nr. 4, 302-309. Auch separar: Gubbio: Oderisi, 1936. 10 S.

Pelloux, Luigi: Il problema del male nella dottrina di Kant. In: Rivista di Filosofia NeoScolastica (Milano) 27, 1935, 125-136.

RASKER, Albert Jan: De ethiek en het probleem van het booze. Een studie naar aanleiding van de ethische en godsdienstphilosofische geschriften van Immanuel Kant. Assen: Van Gorcum [1935]. 202 S. [Proefschrift Groningen (Rijksuniv.) Godgeleerdheid, 1935].

SAMUEL, O.*: Der ontologische Gottesbeweis bei Karl Barth, Immanuel Kant und Anselm von Canterbury. In: Theologische Blätter (Leipzig) 14, 1935, 141-153.

Buccellato, M.*: Presupposti metafisici dell'Analitica e Dialettica del Bello e del Sublime in Kant. In: La Tradizione (Palermo) Nr. 5/6, 1936, 199-204.

JORDAAN, Pieter Willem: Die godsbegrip en godsbewyse in die moderne wysbegeerte van Descartes en Kant. M. A. Potchefstroom University, 1936. *

Paton, Herbert J[ames]: Kant's Metaphysic of Experience. A Commentary on the First Half of the Kritik der reinen Vernunft. 2 Bde. London / New York 1936. Rezensionen: R. F. A. Hoernlé. In: Mind 46, 1937, 492-504; H. W. Stuart. In: The Philosophical Review (New York) 47, 1938, 420-433. E. Cassirer. In: Theoria (Lund) 6, 1940, 87-100.

BEYER, Kurt: Kants Vorlesungen über die philosophische Religionslehre. Halle: Akad. Verlag, 1937. 271 S. [Zugl. Univ. Diss.: Halle, u. d. T.: Untersuchungen zu Kants Vorlesungen über die philosophische Religionslehre (64 S., Teildr.).]

EIBL, Hans: Kants Metaphysik in der Dissertation von 1770. In: Blätter für Deutsche Philosophie (Berlin) 11, 1937, 152-176.

HoERnLE, R. F. A[lfred]: H. J. Paton: Kant's Metaphysic of Experience. [A Critical Notice.] In: Mind 46, 1937, 492-504.

Masnovo, A.*: L'ascesa a Dio in R. Cartesio ed E. Kant. In: Congrès Descartes. Travaux du IXe Congrès International de Philosophie. Hrsg. von Raymond Bayer. 12 Bde. Paris: Hermann, 1937. Bd. I: Études cartésiennes, 111-117. *

KAROESKI, Walter: Der Kirchenbegriff Kants. In: Zeitschrift für systematische Theologie (Berlin) 14, 1937, 532-543. 
REICH, Klaus: Kants einzig möglicher Beweisgrund zu einer Demonstration des Daseins Gottes. Ein Beitrag zum Verständnis des Verhältnisses von Dogmatismus und Kritizismus in der Metaphysik. Leipzig: Meiner, 1937. 43 S. [Forschungen zur Geschichte der Philosophie und der Pädagogik, 17.]

SCHULKE, Horst: Kants und Luthers Ethik. Ein Vergleich unter besonderer Berücksichtigung der Lehre vom Bösen. Phil. Diss.: Greifswald, 1937. $111 \mathrm{~S}$.

SPIRA, Zygmunt: Mechanistyka ewolucyjna Kanta w N̈wietle jego przedkrytycznej metafizyki [Die Evolutionsmechanistik Kants im Lichte seiner vorkritischen Metaphysik]. Phil. Diss.: Kraków 1937.

\section{8}

BOHATEC, Josef: Die Religionsphilosophie Kants in der "Religion innerhalb der Grenzen der bloßen Vernunft". Mit besonderer Berücksichtigung ihrer theologisch-dogmatischen Quellen. Hamburg: Hoffmann und Campe, 1938. 643 S. Rezensionen: S. de Coster. In: Revue Internationale de Philosophie (Bruxelles) 1, 1939, 763-765. W. Goossens. In: Revue Néo-Scolastique de Philosophie (Louvain) 43, 1940, 108-109. Nink. In: Scholastik (Eupen) 15, 1940, 115-116. H. J. de Vleeschauwer. In: Tijdschrift voor Philosophie (Gent) 2, 1940, 463-464.

GERSCH, Walter: Der transzendentale Existenzbeweis in Kants kritischer Metaphysik der außerbewußten Wirklichkeit. Würzburg: Triltsch 1938. [Zugl. Phil. Diss.: Marburg, 1938.] VIII, 81 S. Rezensionen: M. M[andelbaum]. In: The Journal of Philosophy (New York) 36, 1939, 329-330; W. Karowski. In: Theologisches Literaturblatt (Leipzig) 64, 1939, 146-147; E. Wentscher. In: Archiv für die gesamte Psychologie (Leipzig) 104, 1939, 349; Th. Ballauff. In: Blätter für deutsche Philosophie (Berlin) 13, 1939, 309310.

MUgLER, Edmund: Gottesdienst und Menschenadel. Die sittliche Idee im Kampfe um ihre Selbstbehauptung innerhalb der israelitisch-jüdischen und christlichen Religionsgeschichte. I. Kant - Schiller. Stuttgart: Frommann, 1938.

Pinto de Carvalho, António: A metafísica de Kant. In: Brotéria (Lisboa) 27, 1938, 368377.

BOwERS, David F.: Kant's Criticism of Metaphysics. In: The Heritage of Kant. Hrsg. von G. T. Whitney und D. F. Bowers. Princeton 1939, 139-159.

Brahma, N. K.: Is Metaphysics Possible? A Study of Kant. In: Calcutta Review 73, 1939, 63-77.

DARKIN, A. Hazard: Kant and Religion. In: The Heritage of Kant. Hrsg. von G. T. Whitney und D. F. Bowers. Princeton 1939, 405-420.

JANSEN, Bernhard: Das Problem der Metaphysik in philosophiegeschichtlicher Schau. Aristoteles - Kant. In: Gregorianum (Rom) 20, 1939, 207-236. Rezensionen: [Anon.] In: Brotéria (Lisboa) 30, 1940, 101-103. 
LUTHER, Kant, Schleiermacher in ihrer Bedeutung für den Protestantismus. Forschungen und Abhandlungen. Georg Wobbermin zum 70. Geburtstag dargebracht. Hrsg. v. Friedrich Wilhelm Schmidt, Robert Winkler, Wilhelm Meyer. Berlin: Arthur Collignon Verlag, 1939. XVI, $589 \mathrm{~S}$.

PARIANI, M. R.*: Critiche alla concezione morale e religiosa di Kant. In: Rivista Rosminiana di Filosofia e di Cultura (Pallanza) 33, 1939, 171-180.

SCHUlZE-MAIZIER, Friedrich: Kant als protestantischer Denker. In: Eckart. Blatt für evangelische Geisteskultur (Witten) 15, 1939, 373-380.

WaLSH, William Henry: Kant's Criticism of Metaphysics II. In: Philosophy (London) 14, 1939, 313-325; 434-448.

\section{0}

COTTIER, Athanas: Der Gottesbeweis in der Geschichte der modernen Aufklärungsphilosophie. Descartes - Leibniz - Wolff - Kant. Bern: Lüthy 1943. $176 \mathrm{~S}$. [Phil. Diss.: Freiburg (Schweiz), 1940.]

REUTHER, H.*: Naturwissenschaft und Religion bei Platon und Kant. In: Mitteilungen der deutschen Gesellschaft zur Erforschung vaterländischer Sprache und Altertümer 14, 1940, 7-32.

SABETTI, A.*: Attualità e cristianesimo nel problema metafisica Kantiano. In: Logos (Napoli/Roma) 23, 1940, 278-294.

\section{1}

Heimsoeth, Heinz: Kants philosophische Entwicklung. Ein Beitrag zum Thema "Metaphysik» und "Kritik" im Kantischen Lebenswerk. In: Blätter für Deutsche Philosophie (Berlin) 14, 1940/41, 148-166.

MYLIUS, Irmgard: Das transzendentale Ideal in der transzendentalen Frage(stellung) Kants, dargestellt im Ausgang von der Wolffschen Metaphysik. Phil. Diss.: Freiburg i. B., 1941.90 gez. Bl. [Typoskript]

\section{2}

BERBERICH, Gerta: La notion métaphysique de la personne chez Kant et Kierkegaard. Fribourg: Impr. S. Paul, 1942. 81 S. [Univ. Diss.: Fribourg (Schweiz), 1942.]

LAZZARINI, Renato: Dalla religione prekantiana alla religione morale di Kant. Roma: Perrella, 1942. $80 \mathrm{~S}$.

MartinetT, Piero: La religione secondo E. Kant [1928]. In: Martinetti, Piero: Ragione e fede. Saggi religiosi. Torino: Einaudi, 1942, 73-95.

PELloux, Luigi: Una rivalutazione dell'esperienza religiosa kantiana. In: Rivista di Filosofia Neo-Scolastica (Milano) 34, 1942, 171-173. [Zu: Kant, E.: La religione entro i limiti della sola ragione. Erste Übersetzung aus dem Deutschen. Hrsg. von Alfredo Poggi. Modena, 1941.] 


\section{3}

HeYse, Hans: Unser Verhältnis zum Griechentum als metaphysisches Problem. In: KantStudien (Berlin) 43, 1943, 227-262.

HeYSE, Hans: Kant y la metafísica antigua. In: Anales de la Asociación EspaZola para el Progreso de las Ciencias (Madrid) 9, 1944, Nr. 2, 353-362.

HEYSE, Hans: La metafísica de la experiencia en Kant. In: Anales de la Asociación EspaZola para el Progreso de las Ciencias (Madrid) 9, 1944, Nr. 2, 367-377.

JANDL, Ernest: Leibniz und Kant. Ein Beitrag zu ihrer Erkenntnistheorie und Metaphysik. Phil. Diss.: Wien, 1943. 118 gez. Bl. (Maschinenschr)

SChelnberguer, August: Kants Metaphysik in der Dissertation von 1770 und in der Kritik der reinen Vernunft. Phil. Diss.: Wien, 1943. II, 243 gez. Bl. (Maschinenschr.)

SCHRADER, George A.: Kant's Critical Method and its Implications for our Knowledge of God. Univ. Diss.: Yale University 1945.

\section{6}

CaStellani, Leonardo - Maréchal, Joseph: La "Crítica" de Kant. Introducción al kantismo. (Sección tercera de la magna obra del cimiento de la Metafísica. Lecciones sobre el desarrollo histórico y teorético del problema del conocimiento.) Buenos Aires 1946.

Gross, Harold H.: The Relation Between Religion and Morality in Immanuel Kant and John Wood Oman. Univ. Diss.: University of Iowa 1946.

PRINI, Pietro: Linterpretazione metafisica del Kantismo e il "Kant» di Piero Martinetti. In: Giornale di Metafisica (Genova) 1, 1946, 506-510.

\section{7}

MARECHAL, Joseph: Le point de départ de la métaphysique. Cahier IV: Le système idéaliste chez Kant et les postkantiens. Bruxelles - Paris 1947. Rezensionen: J. V. Flynn. In: Thought XXII, 1948, 359-360; S. Cuesta. In: Razón y Fe (Madrid) 618/19, 1949, 123 124.

MarTIN, Gottfried: Die metaphysischen Probleme der Kritik der reinen Vernunft. In: Zeitschrift für philosophische Forschung (Frankfurt a. M.) 2, 1947, 315-342. Auch in: Ders.: Gesammelte Abhandlungen Bd. I. Köln 1961, 55-79.

EKLUND, Harald: Die Würde der Menschheit. Über die erkenntnistheoretischen Voraussetzungen der Religionsphilosophie bei Kant. In: Uppsala Universitets Årsskrift (Uppsala) 8, 1947, 5-144. Rezensionen: W. H. Bernhardt. In: Journal of Religion (Chicago) 29, 1949, 159-160. 


\section{8}

OSHIMA, Yasumasa: Kants Vernunft, Moral und Religion [japanisch]. In: Tetsugaku Kenkyu (Kyoto) 374, 1948, 1-25 und Tetsugaku Kenkyu (Kyoto) 379, 1948, 1-20 und Tetsugaku Kenkyu (Kyoto) 381, 1948, 1-20.*

PALOMINIO BECERRA, Demetrio: Kant y la metafisica. In: Letras (Lima) 39-41, 14, 1948, $107-111$.

1949

HESSEN, Johannes: Recht und Unrecht in Kants Kritik der Gottesbeweise. In: Philosophische Studien (Berlin) 1, 1949, 260-277.

KLAMP, Gerhard: Zum Problem der Textverschiebung in Kants Grundlegung zur Metaphysik der Sitten. In: Zeitschrift für philosophische Forschung (Frankfurt a. M.) 4, 1949, 574-578.

KLAUNZLER, Pirmin: Wesen und Aufgabe der Imaginatio in der Erkenntnismetaphysik des Thomas von Aquin verglichen mit der Lehre des Schematismus der transzendentalen Einbildungskraft bei Kant. Univ. Diss.: Würzburg 1949. [Typoskript]

ReINER, Hans: Eine Textverschiebung in Kants Grundlegung zur Metaphysik der Sitten. In: Zeitschrift für philosophische Forschung (Frankfurt a. M.) 4, 1949, 123-124.

SHIMA, Yoshio: Über die Beziehung zwischen Moral und Religion bei Kant [japanisch]. In: Tetsugaku Kenkyu (Kyoto) 380, 1948, 647-664 und Tetsugaku Kenkyu (Kyoto) 382, 1949, 1-16.

EbBinghaus, Julius: Kants Beweis von der Anfangslosigkeit der Welt in der ersten Antinomie. In: Mélanges Maréchal, Bd. II. Bruxelles 1950, 396-407.

KLAUSEN, Sverre: Kants laere om rettferdiggjörelsen og den saliggjörende tro (La théorie de Kant concernant la justification et la foi). In: Religion och Kultur (Oslo), 21, 1950, 28-34.*

\section{1}

Daval, Roger: La métaphysique de Kant. Perspectives sur la métaphysique de Kant d'après la théorie du schématisme. Paris 1951. [Thèse Lettres Paris 1949.] Rezensionen: C. Goretti. In: Rivista Internazionale della Filosofia del Dirito (Milano) 29, 1952, 525530; J. Kopper. In: Philosophischer Literaturanzeiger (Frankfurt a. M.) 4, 1952, 106112.

KARAPET]AN, A[ramais] A[rÓakovi...]: Kantovskoe obosnovanie metafiziki kak aristokrati...eskaja reakcija $\mathbf{v}$ filosofii [Kants Begründung der Metaphysik als aristokratische Reaktion in der Philosophie]. Autoreferat der Dissertation zur Erlangung des akademischen Grads eines Doktors der philosophischen Wissenschaften (Moskauer Universirät). Erevan 1951 [68 S.].

OGURA, Yukiyoshi: Kants Metaphysik und die Ethik [japanisch]. In: JP 712, 1951, 84-107. 
BARRET, Earl E.: Types of Religious Certainty Implied by Kant's Treatment of the Problem of God. Univ. Diss.: Boston University 1952.

HALlDEN, Sören: Kants Kritik des ontologischen Gottesbeweises. In: Theoria (Lund ) 18, $1952,1-31$.

INOUE, Tadashi: Über Kants metaphysische Erforschung der physiologischen Methode [japanisch]. In: The Hiroshima University Studies 2, 1952, 1-16.

MIHARA, Yoshinobu: Die Bedeutung der Metaphysik bei Kant [japanisch]. In: JP 715, 1952, 110-131.*

SÖHNGEN, Gottlieb: Kants Kritik der Gottesbeweise in religiös-theologischer Sicht besonders von Anselms ontologischem Argument her. In: Söhngen, Gottlieb: Die Einheit in der Theologie. Gesammelte Abhandlungen, Aufsärze, Vorträge. München 1952, 140-160.

SOHNGEN, Gottlieb: Die Theologie im «Streit der Fakultäten». In: Söhngen, Gottlieb: Die Einheit in der Theologie. Gesammelte Abhandlungen, Aufsätze, Vorträge. München 1952, 2-21.

\section{3}

Caracciolo, Alberto: Arte e pensiero nelle loro istanze metafisiche. (Ripensamento dei problemi della Critica del giudizio). Milano - Roma 1953.

Clive, Geoffrey H.: The Connection between Ethics and Religion in Kant, Kierkegaard, and F. H. Bradley. Univ. Diss.: Harvard University 1953.

JANOSKA, Georg: Kant und Schestow. Ein Beitrag zum Glaubensproblem. Graz 1952/53. Rezensionen: R. Freundlich. In: Philosophischer Literaturanzeiger (Frankfurt a. M.) 5 , 1952/53, 119-122.

JASPERS, Karl: El mal radical en Kant. In: Balance y Perspectiva. Discursos y ensayos. Aus dem Deutschen übersetzt von Fernando Vela. Madrid 1953.

HeIDEgGer, Martin: Kant et le problème de la métaphysique (Kant und das Problem der Metaphysik). Eingeleitet und übersetzt von Alphonse de Waelhens und Walter Biemel. Paris 1953. Rezensionen: J. Gérard. In: Revue Internationale de Philosophie (Bruxelles) 7, 1953, 404-408; P. Thévenaz. In: Revue de Théologie et de Philosophie (Lausanne) 4, 1953, 301. [1954 ins Spanische und ins Japanische übersetzt.]

KOPPER, Joachim: Der ontologische Gottesbeweis Anselms und der moralische Gottesbeweis Kants. In: Annales Universitatis Saraviensis Phil. T. 2, 1/2, 1953, 73-80.

MEYER, Hermann Josef: Das Problem der Kantischen Metaphysik unter besonderer Berücksichtigung des Opus postumum. Ein systematischer Versuch. Phil. Diss.: Tübingen 1953 [Typoskript]. 
1954

FeIBleman James K.: Kant and Metaphysics. In: Tulane Studies in Philosophy 3, 1954, 55-88. GaHRINGER, Robert E.: The Metaphysical Aspects of Kant's Moral Philosophy. In: Ethics (Chicago) 64, 1954, 277-291.

GlasenapP, Helmut von: Kant und die Religionen des Ostens. Kitzingen 1954 [21959]. Rezensionen: Paul Menzer. In: Theologische Literaturzeitung (Berlin) 80, 1955, 335-337.

HeIDEGGER, Martin: Kant y el problema de la metafísica. Übersetzt von G. I. Roth. México 1954.

PAgGiario, Luigi: La religione di Kant è religione senza Dio? In: Sophia (Padova) 22, 1954, Nr. 3/4, 331-337.

Ross, David: Kant's Ethical Theory. A Commentary on the "Grundlegung zur Metaphysik der Sitten». Oxford 1954.

ROTENSTREICH, Nathan: Kant's Concept of Metaphysics. In: Revue Internationale de Philosophie (Bruxelles) 8, 1954, 392-408.

SCHADE, Rudolf G.: The Roots and Effects of Kant's Concept of God and Man. Northern Baptist Theological Seminary 1954.

STECK, Karl-Gerhard: Kant und die Theologie. In: KuW (Frankfurt a. M.) 1954, 43-48.

TACHI, Kido: Das Schicksal der Vernunft. Die Probleme der Grenzen der Vernunft und des Gottes in der kritischen Philosophie Kants [japanisch]. Japan Society for the Promotion of Science. Tokyo 1954.*

VASA, Andrea: Il problema religioso nel pensiero kantiano. I: Dall'ottimismo metafisico al trascendentalismo dell'intenzione morale. In: Rivista Critica di Storia della Filosofia (Firenze) 9, 1954, 344-366.

Whittemore, R[obert] C.: The Metaphysics of the Seven Formulations of the Moral Argument. In: Tulane Studies in Philosophy 3, 1954, 133-161.

1955

BlumenBERG Hans: Kant und die Frage nach dem "gnädigen Gott». In: Studium Generale (Berlin) 7, 1954/55, 554-570.

MarTIN, Gottfried: Kant's Metaphysics and Theory of Science. Übersetzt von P. G. Lucas. Manchester 1955. Rezensionen: J. D. In: Il Politico. Rivista di Scienze Politiche (Pavia) $2,1956,478$.

PASTORE, Annibale: Il segreto di Kant ossia la metafisica della metafisica. In: Atti dell'Accademia delle Scienze di Torino. Classe di scienze morali, storiche e filologiche (Torino) 89, 1954/55, 3-38.

Roméro, Silvio: Kant e a metafisica. In: Revista Brasileira de Filosofia (São Paulo) 5, 1955, 463-465 [Auszug aus: S. Roméro: Doutrina contre doutrina. Hrsg. von J. B. Nuñes. Rio de Janeiro la série 1894, 323-327]. 
RuST, Hans: Kritisches zu Kants Religionskritik. In: Jahrbuch der Albertus-Universität Königsberg 6, 1955, 73-106.

SCIACCA, Michele-Federico: Rosmini et Kant: le problème de la métaphysique. Übersetzt von D. Dreyfus. In: Etudes Philosophiques (Paris) 10, 1955, 255-259.

Vuillemin, Jules: Physique et métaphysique kantiennes. Paris 1955. Rezensionen: F. Barone. In: Scientia (Bologna) 12, 1956, 396.

\section{6}

Granger, Gilles Gaston: Kant selon l'ordre des raisons. Sur le livre de Jules Vuillemin: Physique et métaphysique kantienne. In: Revue de Métaphysique et de Morale (Paris) $61,1956,195-200$.

Heimsoeth, Heinz: Studien zur Philosophie Immanuel Kants. Metaphysische Ursprünge und ontologische Grundlagen. Köln 1956. . [KSEH 71.] Rezensionen: G. KahlFurthmann. In: Philosophischer Literaturanzeiger (Frankfurt a. M.) 10, 1957, 347352; V. Mathieu. In: Filosofia (Torino) 8, 1957, 159-161; G. Tonelli. In: Archives de Philosophie (Paris) 1957, 3, 195-196. - Darin:

Christian Wolffs Ontologie und die Prinzipienforschung I. Kants. Ein Beitrag zur Geschichte der Kategorienlehre, 1-92; Der Kampf um den Raum in der Metaphysik der Neuzeit, 93-124 [1925]; Metaphysik und Kritik bei Chr. A. Crusius. Ein Beitrag zur ontologischen Vorgeschichte der Kritik der reinen Vernunft im 18. Jahrhundert, 125188 [1926]; Metaphysische Motive in der Ausbildung des kritischen Idealismus, 189225 [1924]; Persönlichkeitsbewußtsein und Ding an sich in der Kantischen Philosophie, 227-257 [1924].

HildebrandT, Kurt: Kant und Leibniz - Kritizismus und Metaphysik. Meisenheim 1956. Rezensionen: G. Hennemann. In: Philosophischer Literaturanzeiger (Frankfurt a. M.) $12,1959,19-23$.

KOPPER, Joachim: Kants Gotteslehre. In: Kant-Studien (Berlin) 47, 1955/56, 31-61.

PATON, H[erbert] J[ames]: The Aim and Structure of Kant's "Grundlegung». In: The Philosophical Quarterly (St. Andrews) 8, 1956, 112-130.

RaEDemaeker, F[ranciscus] de: Wat dacht Kant over God? In: Streven (Antwerpen) 8, Nr. $2,1955 / 56,402-409$.

Thevenz, Pierre: La critique comme métaphysique de la métaphysique. Trois leçons sur Kant. In: Revue de Théologie et de Philosophie (Lausanne) 6, 1956, 216-248.

\section{7}

ANTWEILER, Anton: Der Zweck in Religion und Moral. Zu Kants «Religion innerhalb der Grenzen der bloßen Vernunft». In: Freiburger Zeitschrift für Philosophie und Theologie (Fribourg) 4, 1957, 273-316.

CASSIRER, Ernst: Kant y el problema de la metafísica. Observaciones a la interpretación de Kant de Martín Heidegger. Übersetzt von Ernesto Garzón Valdés. In: Humanitas (Brescia) 8, 1957, 167-193. [Dt. Originalausgabe in Kant-Studien (Berlin) 36, 1/2, Berlin 1931.] 
DRYER Douglas P[oole]: Kant on the Verificability of Metaphysics. In: The Journal of Philosophy (New York) 54, 1957, 143-144.

KeYworTh, Donald Roland: The Status of Theological First Principles According to Hume and Kant. Univ. Diss.: Ohio State University 1957 [O. N. 58005-42].

Pflug, Günther: Roger Daval und seine Rezensenten. [Zu R. Daval: La métaphysique de Kant]. In: Kant-Studien (Berlin) 48, 1956/57, 86-98.

RUST, Hans: Kants Wissenschaftsbegriff und die Metaphysik. In: Jahrbuch der AlbertusUniversität Königsberg 7, 1957, 68-90.

SCHULZE, Wilhelm August: Zu Kants Gotteslehre. In: Kant-Studien (Berlin) 48, 1956/57, 80-84. Ibid.: Kopper, Joachim: Antwort an W. A. Schulze, 84-85.

1958

ABE, Masao: Ist Metaphysik als Wissenschaft möglich? Das letzte Problem von Kants Kritik der reinen Vernunft [japanisch]. In: Tetsugaku Kenkyu (Kyoto) 458, 1958, 967-998.

ARATA, Carlo: A proposito della critica kantiana della metafisica speculativa. In: Giornale di Metafisica (Genova) 13, 1958, 716-735.

BALlaRD, Edward G.: On Kant's Refutation of Metaphysics. In: The New Scholasticism (Washingon) 32, 1958, 235-252.

HARTWIG, Theodor: Kants «Gottesbeweis» und das Sittengesetz. In: Der Freidenker. Organ der freigeistigen Vereinigung der Schweiz (Aarau) 41, 1958, 203-211.

LOTZ, Johannes B.: Metaphysica operationis humanae methodo transcendentali explicata. Romae 1958. [Analecta gregoriana. Vol 94.]

1959

GlaSENAPP, Helmut von: Kant und die Religionen des Ostens. Kitzingen ${ }^{2} 1959$ ['1954].

GUTTMANN, Julius: Kants Gottesbegriff in seiner positiven Entwicklung. Neudruck Würzburg 1959 ['1906; KSEH 1].

KLaUSEN, Sverre: Das Problem der Erkennbarkeit der Existenz Gottes bei Kant. Oslo 1959.

NAVRATIL, Karl: Wie ist Metaphysik nach Kant möglich? In: Kant-Studien (Berlin) 50 , 1958/59, 163-177.

OesterReich, Traugott Konstantin: Kant und die Metaphysik. Neudruck Würzburg 1959 ['1906; Kant-Studien (Berlin)EH 2].

1960

ChurChILl, James Spencer: Martin Heidegger, Kant, and the Problem of Metaphysics. Translated with an Introduction and Notes. Univ. Diss.: Indiana University 1960 [D.A.I., 21/05, p. 1217 ; O. N. 60028-05]. 
KaUlbaCH, Friedrich: Die Metaphysik des Raumes bei Leibniz und Kant. Köln 1960. Rezensionen: U. Arnold. In: WZPh 7, 1959-1962, 261-264; W. Ritzel. In: Philosophischer Literaturanzeiger (Frankfurt a. M.), 14, 1961, 108-114; anon. In: Sophia (Padova) 30, 1962, 384; H. Heimsoeth. In: Philosophische Rundschau (Tübingen) 12, 1964, 229-234; F. Brunner. In: Revue de Théologie et de Philosophie (Lausanne) $15,1965,328-329$.

SCHILling Kurt: Der Platz für den Glauben. Zur Problematik der Gottesvorstellungen im Anschluß an Kants "Kritik der reinen Vernunft». In: Kant-Studien (Berlin) 51, 1959/60, 67-84.

REINHARD, Edmund: Kants “Ding an sich» im Lichte der Gotteserkenntnis. In: Der Quell. Zeitschrift für Geistesfreiheit (Pähl b. Weilheim) 12, 1960, 116-125 und 174-181.

SCHILling, Kurt: Der Platz für den Glauben. Zur Problematik der Gottesvorstellungen im Anschluß an Kants "Kritik der reinen Vernunft". In: Kant-Studien (Berlin) 51, 1959/60, 67-84.

\section{1}

ANTWEILER, Anton: Die Anfangslosigkeit der Welt nach Thomas von Aquin und Kant. Trier 1961. Rezensionen: C. H. Henkey. In: Theological Studies (Baltimore) 22, 1961, 712713; L. Renwart. In: NRTh 84, 1962, 324; G. Philips. In: Ephemerides Theologicae Lovanienses (Louvain) 38, 1962, 573-574; V. Richter. In: Zeitschrift für katholische Theologie (Wien) 85, 1963, 241-242; E. Nickel. In: ThR 59, 1963, 228; F. V. In: Bulletin de Théologie Ancienne et Médiévale (Louvain) 9, 1963, 395; R. Bomba. In: Philosophisches Jahrbuch der Görresgesellschaft (München) 71, 1963/64, 170-171; W. Brugger. In: Scholastik (Eupen) 40, 1965, 136-137.

KOPPER, Joachim: Thomas von Aquins Lehre über das Wissen der erkennenden Seele von sich selbst und von Gott im Hinblick auf Kant. In: Zeitschrift für philosophische Forschung (Frankfurt a. M.) 15, 1961, 374-388.

MaRTIN, Gottfried: Kant im Lichte der aristotelischen Metaphysik. In: Gesammelte Abhandlungen Bd. I. Köln 1961, 86-96.

MarTin, Gottfried: Probleme der Prinzipienlehre in der Philosophie Kants. In: KantStudien (Berlin) 52, 1960/61, 173-184.

PONCELET, A[lbert?]: God in het Opus postumum van Immanuel Kant. In: Bijdragen (Antwerpen) 22, 1961, 55-68. *

TOPITSCH, Ernst: Motive und Modelle der Kantischen Moralmetaphysik. In: TOPITSCH, Ernst: Sozialphilosophie zwischen Ideologie und Wissenschaft. Neuwied 1961, 201234.

\section{2}

BRANDENSTEIN, Béla von: Metaphysische Beweise unter besonderer Berücksichtigung der Transzendentalen Dialektik Kants. In: Kant-Studien (Berlin) 53, 1961/62, 129-191.

GUTHRIE, George Paul: Kant and Ritschl: A Study in the Relation Between Philosophy and Theology. Univ. Diss.: University of Chicago 1962. 
OvSJANNIKOV, $\mathrm{M}$ [ihail] F[edorovi...]: ZaÓ...ita religii I. Kantom [Kants Verteidigung der Religion]. In: Istorija i teorija ateizma [Geschichte und Theorie des Atheismus]. Moskva 1962, 215-218.

REDMANN, Horst-Günther: Gort und Welt. Die Schöpfungstheologie der vorkritischen Periode Kants. Göttingen 1962. Rezensionen: W. Pannenberg. In: Theologische Literaturzeitung (Berlin) 89, 1964, 897-906; D. Zaslawsky. In: Revue de Théologie et de Philosophie (Lausanne) 18, 1968, 57.

ROHRMOSER, Günter: Die theologische Bedeutung von Hegels Auseinandersetzung mit der Philosophie Kants und dem Prinzip der Subjektivität. In: Neue Zeitschrift für systmatische Theologie (Berlin) 4, 1962, 89-111.

RusT, Hans: Intellectus quaerens fidem. Vom bleibenden Sinn und Wert der sogenannten Gottesbeweise im Anschluß an Kant. In: Jahrbuch der Albertus-Universität Königsberg 12, 1962, 5-19.

SANTELER, Josef: Die Grundlegung der Menschenwürde bei Immanuel Kant. Eine systematisch kritische Studie. Innsbruck 1962. Rezensionen: O. Lechner. In: The Southern Journal of Philosophy (Memphis) 7, 1963, 245-246; A. Pechhacker. In: Zeitschrift für katholische Theologie (Wien) 85, 1963, 239-240; J. de Vries. In: Scholastik (Eupen) 39, 1964, 140-141; L. Martin-Gómez. In: Pensamiento (Madrid) $21,1965,341-342$.

TSUNETOSHI, Sozaburo: Kants Metaphysik [japanisch]. In: Tetsugaku Kenkyu (Kyoto) 481, 1962, 914-935.

Zimmerman, Robert Lloyd: Kant, Schiller, and Hegel. A Study in Metaphysical Aesthetics. Diss. New York University 1962 [D.A.I., 23/06, p. 2174; O.N. 62053-89].

\section{3}

DRYer, D [ouglas] P[oole]: The Aim of the Critique of Pure Reason. In: Dialogue 2, 1963, 301-312.

GaRULLIN, Enrico: Esperienza e metafisica nella filosofia moderna. Urbino 1963.

HeIMSOETH, Heinz: Astronomisches und Theologisches in Kants Weltverständnis. Mainz Wiesbaden 1963.

HeNRICH, Dieter: Das Problem der Grundlegung der Ethik bei Kant und im spekulativen Idealismus. In: Sein und Ethos. Untersuchungen zur Grundlegung der Ethik. Hrsg. von Paulus Engelhardt. Mainz 1963, 350-386.

SCHMUCKER, Joseph: Die Gottesbeweise beim vorkritischen Kant. In: Kant-Studien (Berlin) $54,1963,445-463$.

VlaChOS Georges: La pensée politique de Kant. Métaphysique de l'ordre et dialectique du progrès. Vorwort: M. Prélot. Paris 1963 [11962].

WALSH, William Henry: Kant's Moral Theology. In: PBA 49, 1963, 263-289. 
BAUER, Johannes: Zum einzig möglichen Gottesbeweis. In: The Southern Journal of Philosophy (Memphis) 7, 1964, 161-174.

BAUMER, William H.: Kant on "God is»: A Reply to Mr. Engel (S. M. Engel: Kant's "Refutation»). In: Kant-Studien (Berlin) 55, 1964, 498-504.

BossarT, William H.: Kant and some Metaphysicians. In: Kant-Studien (Berlin) 55, 1964 , 20-36.

Feibleman, James K.: Kant and Metaphysics. In: Tulane Studies in Philosophy 13, 1964, 55-88 [Reprint von 1954].

FLEISCHER, Margot: Die Formeln des kategorischen Imperativs in Kants «Grundlegung zur Metaphysik der Sitten». In: Archiv für Geschichte der Philosophie (Berlin/New York) 46, 1964, 201-226.

GaUCHHWAL, Balbir Singh: Moral Religion of Kant and Karmayoga of the Gita. In: KantStudien (Berlin) 55, 1964, 394-409.

JACOBELLI IsOLDI, Angela Maria: Il concetto tradizionale di metafisica e l'antimetafisica kantiana. Anno accademico 1963/64. Roma 1964.

Krull, K.: The Existence of God, Scotus, and Kant. In: Duns Scotus Philosophical Association 28, 1964, 142-177.*

LAMACCHIA, Ada: Le "Lezioni accademiche di filosofia della religione» di Emanuele Kant (1783-1784). Bari 1964.*

LIACI, Maria Teresa: La comunicazione dal piano metafisico al piano esistenziale in Kant precritico. In: Studia Patavina (Padua) 11, 1964, 487-492.

LOWITH Karl: Das Verhältnis von Gott, Mensch und Welt in der Metaphysik von Descartes und Kant. Heidelberg 1964. Rezensionen: H. Kunz. In: Studia Philosophica (Basel) 25, 1965, 205-207; R. W. K. Paterson. In: The Philosophical Quarterly (St. Andrews) 18, 1968, 268-269.

MARC-WogaU, Konrad: Bemerkungen zu Kants Kritik des ontologischen Gottesbeweises. In: Danish Yearbook of Philosophy (København) 1, 1964, 85-95.

MÜlleR, Wolfgang Hermann: Philosophische Besinnung auf die Herkunft der neueren Metaphysik aus Kant. Torino 1964.

PANnenberG, Wolfhart: Theologische Motive im Denken Immanuel Kants. In: Theologische Literaturzeitung (Berlin) 89, 1964, 897-906.

WaLsh, William H[enry]: Kant's Moral Theology. London 1964.

WhitTemore, R[obert] C.: The Metaphysics of the Seven Formulations of the Moral Argument. In: Tulane Studies in Philosophy 3, 1964, 133-161. [Reprint von 1954.]

BOHATEC, Josef: Die Religionsphilosophie Kants in der "Religion innerhalb der Grenzen der bloßen Vernunft». Hildesheim 1965. [Nachdruck der Ausgabe Hamburg 1936.] 
HeIDEGGer, Martin: Kant und das Problem der Metaphysik. Frankfurt a. M. 31965 [21951].

LAMACCHIA Ada: Le fonti teologico-positive nella filosofia della religione di Kant. In: Universita degli Studi Bari. Annali della Facoltà di Lettere e Filosofia (Bari) 10, 1965, 143-183.

SANTINello, Giovanni: Metafisica e critica in Kant. Bologna 1965. Rezensionen: G. Bortolaso. In: La Civiltà Cattolica (Roma) 1966, II, 160; M. T. Liaci. In: Giornale di Metafisica (Genova) 20, 1966, 710-712; G. Penzo. In: Aquinas (Roma) 10, 1967, 288292; G. Privoznik. In: Salesianum (Roma) 29, 1967, 727-728.

SIGNORINI, Alberto: Sulla concezione kantiana di Stato divino. In: Rivista Internazionale della Filosofia del Dirito (Milano) 42, 1965, 477-509.

VANCOURT Raymond: Kant et la solution rationaliste du problème des religions (I-V). In: Mélanges de science religieuse (Lille) 22, 1965, 153-192.

WAISH, William H[enry]: Kant's Moral Theology. London ${ }^{2} 1965$ ['1964].

\section{6}

BoLLNOw, Otto Friedrich: «Als allein ein gurer Wille...». Zum Anfang der «Grundlegung zur Metaphysik der Sitten». In: Rationalität - Phänomenalität - Individualität. Festgabe für Hermann und Marie Glockner. Hrsg. von Wolfgang Ritzel. Bonn 1966, 165-174.

DESPLAND, Michel Samuel: The Idea of Divine Education: A Study in the Ethical and the Religious as Organizing Themes for the Interpretation of the Life of the Self in Kant, Schleiermacher, and Kierkegaard. Univ. Diss.: Harvard University 1966.

DRYER Douglas P[oole]: Kant's Solution for Verification in Metaphysics. London ${ }^{2} 1966$ ['1963].

DRYER, D[ouglas] P[oole]: The Concept of Existence in Kant. In: The Monist (La Salle) 50, $1966,17-33$.

HeIDEGGer, Martin: Kant and the Problem of Metaphysics. Übersetzt von J. S. Churchill. Bloomington, IN/ London 1966 ['1962].

Heimsoeth, Heinz: Zum kosmotheologischen Ursprung der Kantischen Freiheitsantinomie. In: Kant-Studien (Berlin) 57, 1966, 206-229.

JANOSKA, Georg: Abgrenzung und Grundlegung der metaphysica specialis bei Immanuel Kant. In: Kant-Studien (Berlin) 56, 1966, 277-288.

KaY, Stanley Broughton: Kant on the Existence of God: From the 'Beweisgrund' to the Critical Philosophy. Univ. Diss.: Ohio State University 1966 [D.A.I., 27/09-A, p. 3083; O.N. 67024-66].

Kritik und Metaphysik. Studien. Heinz Heimsoeth zum 80. Geburtstag. Hrsg. von F. Kaulbach und J. Ritter. Berlin 1966. Darin: Belaval, Yvon: Sur un point de comparaison entre Kant et Leibniz, 1-9; HenRiCH, Dieter: Zu Kants Begriff der Philosophie. Eine Edition und eine Fragestellung, 40-59; MENGÜOOGLU, Takiyettin: Der Begriff des Menschen bei Kant, 106-119; SCHMUCKER, P. Joseph: Die Originalität des ontotheologischen Argumentes Kants gegenüber verwandten Gedankengängen bei Leibniz und in der Schulphilosophie der Zeit, 120-133. 
LAMACCHIA, Ada: Il discorso metafisico di Kant nel tentativo di introdurre in filosofia il concetto di "grandezze negative". In: Senso e valore del discorso metafisico (X. Convegno annuale di assistenti universitari di filosofia. Centro di studi filosofici di Gallarate) Padova 1966, 54-69.

Núnez TenORIO, J. Rezensionen: Kant y el problema de la metafisica. In: Cultura Universitaria (Caracas) 92, 1966, 140-153.

ZANGs, Lester: What did Kant do to Metaphysics? In: Annual Report of the Duns Scotus Philosophical Association (Cleveland, OH) 30, 1966, 151-175.

\section{7}

Collins, James: A Kantian Critique of the God-is-dead Theme. In: The Monist (La Salle) $51,1967,536-558$.

GiLl, Jerry H.: Kant, Kierkegaard, and Religious Knowledge. In: Philosophy and Phenomenological Research (Buffalo) 28, 1967, 188-204.

HaRUNa, Sumito: Kants Gottesbeweis in der vorkritischen Periode. Das Problem der Überzeugung [japanisch]. In: Tetsugaku Kenkyu (Kyoto) 506, 1967, 59-88.*

RICHLI, Urs: Transzendentale Reflexion und sittliche Entscheidung. Zum Problem der Selbsterkenntnis der Metaphysik bei Kant und Jaspers. Bonn 1967.

SCHAERER, René: "Si Dieu n'existe pas...". Réflexions sur Kant et Dostö̈evski. In: Revue de Théologie et de Philosophie (Lausanne) 17, 1967, 93-110.

SOLINAS, Giovanni: Il microscopio e le metafisiche. Epigenesi e preesistenza da Cartesio a Kant. Milano 1967. Rezensionen: A. Capecci. In: Giornale di Metafisica (Genova) 26, 1971, 393-397.

VANCOURT, Raymond: Kant et la solution rationaliste du problème des religions (VI-IX). In: Mélanges de Science réligieuse (Lille) 24, 1967, 85-105.

\section{8}

ALQUIE, Ferdinand: La critique kantienne de la métaphysique. Paris 1968. Rezensionen: L. J. In: Bibliographie de la Philosophie (Paris) 16, 1969, 121; J. Kopper. In: Kant-Studien (Berlin) 61,1970, 126-127; F. Marty. In: Archives de Philosophie (Paris) 1971, 86-90; H. Bernard-Maitre. In: Revue de Synthèse (Paris) 91, 1970, 130-132.

BRENTANO, Franz: Über Kants Kritik der Gottesbeweise (1911/12). In: Brentano, Franz: Die vier Phasen der Philosophie und ihr augenblicklicher Stand nebst Abhandlungen über Plotinus, Thomas von Aquin, Kant, Schopenhauer und Auguste Comte. Mit Anmerkungen hrsg. von Oskar KRAUS. Neu eingeleitet von Franziska MayerHillebrand. Zweite, auf Druckfehler durchgesehene, sachlich unveränderte Auflage. Hamburg 1968, 83-87.

BRUCH, Jean-Louis: La philosophie religieuse de Kant. Une analyse des structures du systeme kantien, comparé avec les autres philosophies. Paris 1968. Rezensionen: P. Burgelin. In: Revue d'histoire et de philosophie religieuse (Paris) 49, 1969, 200; M. Simon. In: Revue Internationale de Philosophie (Bruxelles) 23, 1969, 111-119; J. Kopper. In: Kant- 
Studien (Berlin) 61, 1970, 128-132; A.-M. V. In: Bibliographie de la Philosophie (Paris) XVII, 1970, 189-190; F. Marty: Bulletin d'études kantiennes. In: Archives de Philosophie (Paris) 34, 1971, 115-121; A. Augagneur. In: Livres et Lectures (Issy les Moulineaux) 1969, Nr. 244, 314*; B.-M. H. In: Revue de Synthèse (Paris) 90, 1969, 7677; V. Lebeaux. In: Revue des Sciences Philosophiques et Théologiques (Le Saulchoir) 53, 1969, 771-773; H. Rouffanche. In: Revue Philosophique de Louvain 68, 1970, 269272; H. Bernhard-Maitre. In: Revue de Synthèse (Paris) 91, 1970, 131; J. Baufay. In: Nouvelle Revue Théologique (Tournai) 91, 1969, 778; A. Dumas. In: Esprit (Paris) 37, 1969, 940-943; J. Ecole. In: Les Études philosophiques (Paris) 4, 1969, 536; A. L. Martorana. In: Sophia (Padova) 38, 1970, 283-284; M. Nédoncelle. In: Revue des Sciences Religieuses (Strasbourg) 45, 1971, 186-189.

CAPPS, Walter H.: A Via Positiva in Kant. In: Journal of Religion (Chicago) 48, 1968, 351 375.

EnGLAND, F[rederick] E[rnest]: Kant's Conception of God. A Critical Exposition of its Metaphysical Development together with a Translation of the Nova Dilucidatio. Vorwort von G. Dawes Hicks. New York 1968 [11929]. Rezensionen: J. Kopper. In: Kant-Studien (Berlin) 62, 1971, 139-140.

EWING A[lfred] C[yril]: Kant's Attack on Metaphysics [1954]. In: Non-Linguistic Philosophy. London/ New York 1968, 145-162.

GARULL, Enrico: Sintesi scientifica e sintesi metafisica negli scritti precritici di Kant. In: Garulli, Enrico: Esperienza e metafisica nella filosofia moderna. Urbino 1968, 99-132.

GLOCKNER, Hermann: Kant und die Metaphysik in den Jahren des Ubergangs von der Kritik zum Transzendentalismus. In: Glockner, Hermann: Gesammelte Schriften. 4. Bd.: Kulturphilosophische Perspektiven. Studien und Charakteristiken aus der Sphäre der Individualität. Bonn 1968, 175-192.

HaLl, Robert W.: Kant and the Idea of God. In: The Seventh Inter-american Congress of Philosophy. Proceedings of the Congress. Bd. 2. Québec 1968, 276-281.

HurwITZ, Gerald Quincy: A Defense of Kant's Ethics and Metaphysics against Moore's Early Criticism. Univ. Diss.: Johns Hopkins University 1968 [D.A.I., 31/08-A, p. 4217; O.N. 71029-53].

IMAIZUMI, Motoji: Das Gottesproblem bei Kant [japanisch]. In: Riso (Tokyo) 427, 1968, 67-79 [fortgesetzt].

KRAUSSER, Peter: Úber eine unvermerkte Doppelrolle des kategorischen Imperativs in Kants Grundlegung zur Metaphysik der Sitten. In: Kant-Studien (Berlin) 59, 1968, 318-332.

PETERS, Eugene: Descriptions of God in the Later Writings of Kant. Univ. Diss.: Harvard University 1968.

PINES, Shlomo: Spinoza's Tractatus Theologico-Politicus, Maimonides and Kant. In: Further Studies in Philosophy. Hrsg. mit Unterstützung der Faculty of Humanities von Ora Segal. Scripta Hierosolymitana, vol. 20. Jerusalem 1968, 3-54.

Sellars, Wilfrid: Science and Metaphysics. Variations on Kantian Themes. London 1968. Rezensionen: B. B. R. In: Bibliographie de la Philosophie (Paris) 16, 1968, 8384; J. J. C. Smart. In: Australasian Journal of Philosophy (Sidney) 47, 1969, 80-82; 
B. Aune. In: The Journal of Philosophy (New York) 68, 1970, 251-256; R. Rorty. In: Philosophy (London) 45, 1970, 66-70; G. Harman. In: The Philosophical Review (Ithaca, NY) 79, 1970, 404-419; vgl. auch den Beitrag von Bernard Gendron: The Foundation of Scientific Realism: A Critical Review of Wilfrid Sellars' Science and Metaphysics. In: International Philosophical Quarterly (New York) 10, 1970, 129-151; V. F. Lenzen. In: Philosophy and Phenomenological Research (Buffalo) 30, 1969/70; K. B. Pflaum. In: PhSt (Maynooth) 18, 1969, 233235; L. Srevenson. In: The Philosophical Quarterly (St. Andrews) 20, 1970, 86-87; Nyíri. In: Inquiry (Oslo) 13, 1970, 321-331; D. H. Mellor. In: Ratio 13, 1971, 8689; J. Kopper. In: Kant-Studien (Berlin) 63, 1972, 125-127; E. B. Allaire. In: Metaphilosophy (GB-Oxford) 2, 1971, 352-358; J. A. Bailey. In: Dialogue (Montréal) 10, 1971, 793-796; S. A. Erickson. In: The Journal of the History of Philosophy (Berkeley, CA) 10, 1972, 111-114; vgl. auch Mackinnon, Edward: Science and Metaphysics. Variations on Kantian Themes. A Critical Review. In: The Philosophical Forum (Boston) 1, 1969, 509-545.

STEGMÜLLER, Wolfgang: Gedanken über eine mögliche rationale Rekonstruktion von Kants Metaphysik der Erfahrung, Teil II: Die logische Struktur des progressiven Argumentes. In: Ratio (Frankfurt) 10, 1968, 1-31; - dasselbe in engl. Sprache (Towards a Rational Reconstruction of Kant's Metaphysics of Experience, II). In: Ratio (Oxford) 10, 1968, $1-37$.

WooD, Allen William: Kant's Moral Religion. Univ. Diss.: Yale University 1968 [D.A.I., 29/11-A, p. 4059; O.N. 69084-57].

Yovel, Yirmiahu: The God of Kant. In: Further Studies in Philosophy. Hrsg. mit Unterstützung der Faculty of Humanities von Ora Segal. Scripta Hierosolymitana, vol. XX. Jerusalem 1968, 88-123.

ZAC, Sylvain: Religion naturelle et religions révélées selon Kant. In: Revue de Métaphysique et de Morale (Paris) 73, 1968, 105-126.

ZAYDAN, Mahmād: Kant wa falsafatuhu l-nazariyya [Kant und die spekulative Philosophie]. Le Claire, Där al-Ma’ãref 1968. Rezensionen: G. C. A[nawati]. In: Bibliographie de la Philosophie (Paris) 18, 1971, 269.

\section{9}

ALlison, Henry E.: Transcendental Idealism and Descriptive Metaphysics [Zu: Peter F. Strawson: The Bounds of Sense]. In: Kant-Studien (Berlin) 60, 1969, 216-233.

ARIfUKu, Kogaku: Die Philosophie nach dem Weltbegriff. Zum Problem der Moral und Religion bei Kant [japanisch]. In: Tetsugaku Kenkyu (Kyoto) 510, 1969, 45-78.

BRUCH, Jean-Louis: Lettres de Kant sur la morale et la religion; introduction, traduction et notes. Paris 1969 [Thèse Lettres compl.: Paris 1968].

BUCHDAHL, Gerd: Metaphysics and the Philosophy of Science. The Classical Origins, Descartes to Kant. Oxford 1969. Rezensionen: J. Kopper. In: Kant-Studien (Berlin) 62, 1971, 126-136; A. C. Michalos. In: Dialogue (Montreal) 9, 1970, 111-113; M. P. Bradie - J. D. Stuart. In: Philosophy of Science (East Lansing) 39, 1972, 267-269; G. W. R. Ardley. In: Philosophical Studies (Dublin) 20, 1972, 287-288; L. Gianformaggio. 
In: Revista de Filosofia (La Plata) 62, 1971, 286-291; G. H. R. Parkinson. In: Studia Leibniziana (Wiesbaden) 3, 1971, 224-227; McRae. In: Studies in History and Philosophy of Science (Pittsburgh) 3, 1972, 89-99; D. J. O'Connor. In: British Journal for the Philosophy of Science (Cambridge) 23, 1972, 79-80; W. von Leyden. In: Philosophy (London) 46, 1971, 38-42; J. D. North. In: The Philosophical Quarterly (St. Andrews) 21, 1971, 184-185; W. Röd. In: Archiv für Geschichte der Philosophie (Berlin/New York) 52, 1971, 100-105; J. O. Salas. In: Anales del Seminario de Metafísica (Madrid) 5, 1970, 90-91.

Collins, James: A Kantian Critique of the God-is-dead Theme [1967]. In: Kant Studies Today. Hrsg. und mit einem Vorwort von Lewis White Beck. La Salle, IL, 1969, 409431.

DERUNGS, Ursicin: Der Moraltheologe J. Geishüttner (1763-1805), Kant und J. G. Fichte. Studien zu den philosophischen Grundlagen der "Theologischen Moral» Joseph Geishüttners. Regensburg 1969. Rezensionen: W. Steinbeck. In: Kant-Studien (Berlin) 61, 1970, 533-535; A. T. Leijen. In: Bijdr 34, 1973, 105; A. Janssen. In: Ephemerides theologicae Lovanienses (Louvain) 45, 1969, 501-502.

ERMECKE, Gustav: «Politische Theologie» im Licht einer realistischen Sozialtheologie. Luther - Kant - Marx: Ante portas... In: Theologie und Philosophie (Freiburg i.Br.) 59, 1969, 282-296; auch in: Diskussion zur "politischen Theologie". Mit einer Bibliographie zum Thema. Hrsg. von Helmut Peukert. München 1969, 162-177.

GUERRA, Augusto: Metafisica e vita morale nel primo scritto kantiano (1746-1747). In: De homine (Roma) 31/32, 1969, 91-118.

Hanada, Nobuhisa: Sittengesetz und Vernunftglaube bei Kant [japanisch]. In: Kant. Hrsg. von Takezo Kaneko. Tokyo 1969, 191-214.

HeimsoeTH, Heinz: Transzendentale Dialektik. Ein Kommentar zu Kants Kritik der reinen Vernunft. 3. Teil: Das Ideal der reinen Vernunft; die spekulativen Beweisarten vom Dasein Gotres; dialektischer Schein und Leitideen der Forschung. Berlin 1969. Rezensionen: J. M. Häußling. In: Wissenschaftlicher Literaturanzeiger (Freiburg) 8, 1969, 39; W. Steinbeck. In: Philosophischer Literaturanzeiger (Frankfurt a. M.) 22, 1969, 196-197; J. Collins. In: The Modern Schoolman (Saint Louis) 47, 1969/70, $377-$ 378; I. Heidemann. In: Philosophy and History (Tübingen) 2, 1969, 27-28; D. Zaslawsky. In: Revue de Théologie et de Philosophie (Lausanne) 21, 1971, 61; R. B. In: Bibliographie de la Philosophie (Paris) 16, 1969, 309-310; F. Marty: Bulletin d'études kantiennes. Le problème métaphysique dans la philosophie de Kant. In: Archives de Philosophie (Paris) 1971, 97-101.

Herring, Herbert: Die Problematik der Leibnizischen Gottesbeweise und Kants Kritik der spekulativen Theologie. In: Studia Leibnitiana (Stuttgart) Supplementa, Bd. 4, 1969, 21-37.

Hicks, Joe Harold: Divine and Human Subjectivity in Kant. Univ. Diss.: Yale University 1969 [D.A.I., 30/08-A; O.N. 70027-41].

IKARASHI, Akira: Die Grenzen der Vernunft in Kants Religionsphilosophie [japanisch]. In: Kant. Hrsg. von Takezo Kaneko. Tokyo 1969, 173-190.

Imaizumi, Motoji: Das Gottesproblem bei Kant [japanisch]. In: Riso (Tokyo) 428, 1969, 64-78 [Fortsetzung von Riso (Tokyo) 427, 1968, 67-79]. 
KLEIBER, M[ichal]: Le problème de l'objectivité de Dieu chez Kant. La modification de l'antithèse: sujet - objet. In: Procès de l'objectivité de Dieu. Les présupposés philosophiques de la crise de l'objectivité de Dieu. Paris 1969, 7-35.

KLEIN, Hans-Dieter: Kants Stellungnahme zum teleologischen Gottesbeweis. In: PhNat 11, $1969,279-290$.

LACORTE, Carmelo: Kant. Ancora un episodio dell'alleanza di religione e filosofia. Urbino 1969. Rezensionen: G. Giannini. In: Aquinas (Roma) 17, 1974, 479; S. Vanni-Rovighi. In: Rivista di Filosofia Neo-scolastica (Milano) 62, 1970, 370; M. Barale. In: KantStudien (Berlin) 64, 1973, 120-126; G. Pennisi. In: Sophia (Padova) 39, 1971, 127 128.

LAMACCHIA, Ada: Autonomia e sufficienza nel rapporto etica - religione nelle "Vorlesungen" di Kant (1762-1764; 1775-1780; 1783-1784). In: Giornale Critico della Filosofia Italiana (Firenze) 48, 1969, 386-399.

LAMACCHIA, Ada: La filosofia della religione in Kant. I. Dal dogmatismo teleologico al teismo morale (1755-1783). Bari 1969. Rezensionen: P. Addante. In: Giornale di Metafisica (Genova) 25, 1970, 490-493; M. Giordano. In: Sapienza (Napoli) 24, 1971, 105-108; U. Margiotta. In: Giornale Critico della Filosofia Italiana (Firenze) 49, 1970, 452-455; M. Barale. In: Kant-Studien (Berlin) 64, 1973, 120-126; E. Merlotti. In: Revue de Theologie et de Philosophie (Lausanne) 21, 1971, 452; A. Rogliano. In: Revista de Filosofia (La Plata) 23, 1973, 70-72; J. Collins. In: The Modern Schoolman (St. Louis, MS) 52, 1974/75, 449-450; G. Giannini. In: Aquinas (Roma) 13, 1970, 478-479; C. A. Orlandi. In: Cuadernos de Filosofía (Buenos Aires) $11,1973,498-503$.

MOREAU, Joseph: Le Dieu des Philosophes (Leibniz, Kant et nous). Paris 1969. Rezensionen: A.-M. Parent. In: Laval Theologique et Philosophique (Québec) 26, 1970, 205-206; J. Kopper. In: Kant-Studien (Berlin) 62, 1971, 145-146; M. Corvez. In: Revue Thomiste (Toulouse) 70, 1970, 323-325; J. Jalabert. In: Revue de Synthèse (Paris) 91, 1970, 295300; G. H. R. Parkinson. In: The Journal of the History of Philosophy (Berkeley, CA) 9, 1971, 130-132; A. Forest. In: Giornale di Metafisica (Genova) 26, 1971, 373-375; F. Brunner. In: Revue de Théologie et de Philosophie (Lausanne) 22, 1972, 302; M. Oliver Narbona. In: Estudios de Metafisica (Valencia) 1971/72, Nr. 2, 275-277; P. Watté. In: Revue Philosophique de Louvain 72, 1974, 402-403; vgl. J. Schmucker: Joseph Moreaus Interpretation der Kantischen Gottesbeweiskritik in «Le Dieu des philosophes». In: Archiv für Geschichre der Philosophie (Berlin/New York) 54, 1972, 37-88.

PINDER, Tillmann: Kants Gedanke vom Grund aller Möglichkeit. Untersuchungen zur Vorgeschichte der "transzendentalen Theologie». Univ. Diss.: FU Berlin 1969.

Ruvo, Vincenzo de: Il pensiero filosofico di E. Kant ovvero. Problemi di critica kantiana. Logica, metafisica, morale ed estetica con un'appendice su significato e valore attuale della pedagogia kantiana. Padova 1969. Rezensionen: E. Namer. In: Revue Philosophique de la France et de l'Étranger (Paris) 95, 1970, 247; B. G. Cataldo. In: Sapienza (Napoli) 23, 1970, 485-487; C. Braciero. In: Il pensiero (Roma/Urbino) 28, 1972, 234-235; C. Terzi. In: Rivista Rosminiana di Filosofia e di Cultura (Domodossola - Milano) 66, 1972, 65-69. 
SILBER, John R[obert]: Die metaphysische Bedeutung des höchsten Gutes als Kanon der reinen Vernunft in Kants Philosophie. In: Zeitschrift für philosophische Forschung (Frankfurt a. M.) 23, 1969, 538-549.

TONELl1, Giorgio: Divinae particula Aurae: Genial Ideas, Organism, and Freedom. A Note of Kant's Reflection N. 938. In: The Journal of the History of Philosophy (Berkeley, CA) $7,1969,192-198$.

VOLlRATH, Ernst: Die These der Metaphysik. Zur Gestalt der Metaphysik bei Aristoteles, Kant und Hegel. Wuppertal - Ratingen 1969. Rezensionen: W. Kern. In: Zeitschrift für katholische Theologie (Wien) 92, 1970, 483-485; J. Simons. In: Kant-Studien (Berlin) 63, 1972, 261-266; Th. Bodammer. In: Archiv für Geschichte der Philosophie (Berlin/New York) 53, 1971, 187-195.

WILD, Christoph: Das Erbe Kants und des deutschen Idealismus. In: Bilanz der Theologie im 20. Jahrhundert. Perspektiven, Strömungen, Motive in der christlichen und nichtchristlichen Welt. Hrsg. von Herbert Vorgrimler, Robert van der Gucht. Bd. I. Freiburg - Basel - Wien 1969, 280-290.

YOVEL, Yirmiahu: Rehabilitation of Metaphysics as the Program of the Critical Philosophy. In: Iyyun (Jerusalem) 20, 1969, 132-185 [engl. Zusammenfassung 301-302].

1970

AGER, Tryg A.: Kant's Theory of Representations: An Interpretation of the Metaphysical and Transcendental Deductions in the "Critique of Pure Reason." Univ. Diss.: University of Pittsburgh 1970 [D.A.I., 31/04-A, p. 1837; O.N. 70183-61].

AlEU, José: Da Kant a Maréchal. Hacia una metafísica de la existencia. Barcelona 1970. Rezensionen: B. Turiel. In: Studium (Madrid) 11, 1971, 179-180; B. Martínez-Ruiz. In: Verdad y Vida (Madrid) 29, 1971, 540-541; R. Celis. In: Revue Philosophique de Louvain 71, 1973, 610-612; C. A. Létora Mendoza. In: Sapienza (Napoli) 28, 1973, 152-153; J.-P. Borel. In: Revue de Théologie et de Philosophie (Lausanne) 23, 1973, Heft 3, 279-280; R. Maliandi. In: Kant-Studien (Berlin) 65, 1974, 93-97; L. M. G. In: Bibliographie de la Philosophie (Paris) 21, 1974, 390; J. Riesco. In: Salmanticensis (Salamanca) 20, 1973, 405-407; A. Deregibus. In: Giornale di Metafisica (Genova) 29, 1974, 417-421; L. Martínez G. In: Pensamiento (Madrid) 30, 1974, 224-225.

BROCKER, Walter: Kant über Metaphysik und Erfahrung. Frankfurt a. M. 1970. Rezensionen: W. Steinbeck. In: Kant-Studien (Berlin) 62, 1971, 257-258; F. W. Korff. In: Zeitschrift für philosophische Forschung (Frankfurt a. M.) 26, 1971, 320-323; E. García Belsunce. In: Cuadernos de Filosofía (Buenos Aires) 11, 1973, 488-490; vgl. auch Becker, Werner: Erkenntnis und Erfahrung in der Transzendentalphilosophie. In: Philosophische Rundschau (Tübingen) 18, 1971, 189-206 [189-197].

CATON, Hiram: Truthfulness in Kant's Metaphysical Morality. In: Essays in Metaphysics. Hrsg. von Carl G. Vaught. University Park/ London 1970, 19-38.

Holz, Harald: Philosophische und theologische Antinomik bei Kant und Thomas von Aquin. In: Kant-Studien (Berlin) 61, 1970, 66-82. 
LAMACCHIA, Ada: Ethik und Religion in den Vorlesungen von Kant (1762-64; 1775-80; 1783-84) (Kurzfassung). In: Akten des XIV. Internationalen Kongresses für Philosophie, Wien 2.-9. September 1968. Bd. V. Wien 1970, 513-517.

LEBRUN, Gérard: Kant et la fin de la métaphysique. Essai sur la «Critique de la faculté de juger». Paris 1970. Rezensionen: Bulletin critique (Paris) Nr. 305, 1971, 579; C[antal] F[avre]. In: Bibliographie de la Philosophie (Paris) 19, 1972, 78; J. Kopper. In: KantStudien (Berlin) 63, 1972, 123-125; J.-C. Margolin. In: Revue de Synthèse (Paris) 93, 1972, 116-118; M. Baum. In: Archiv für Geschichte der Philosophie (Berlin/New York) $57,1975,88-93$.

NYfRI, J[anos] C.: Kant and the New Way of Words. In: Inquiry (Oslo) 13, 1970, 321-331. [Zu: Sellars, Wilfrid: Science and Metaphysics, 1968.]

OTTO, Rudolf: The Philosophy of Religion based on Kant and Fries. Übersetzt von E. B. Dicker mit einem Vorwort von W. Tudor Jones [London 1931]. New York 1970. Rezensionen: R. Malter. In: Kant-Studien (Berlin) 64, 1973, 145-146.

PATON, H[erbert] J[ames]: Kant's Metaphysics of Experience. A Commentary on the First Half of the «Kritik der reinen Vernunft». In two Volumes. London ${ }^{5} 1970\left[{ }^{1} 1936,{ }^{2} 1951\right.$, $\left.{ }^{3} 1961,{ }^{4} 1965\right]$.

PECCORINI, Francisco: A Method of Self-Orientation to Thinking. An Essay on the Use of the Principle of Sufficient Reason in Immanuel Kant's Metaphysics. New York 1970. Rezensionen: K. Oedingen. In: Kant-Studien (Berlin) 63, 1972, 127-128.

REBOUL, Olivier: Kant et la religion. In: Revue d'histoire et de philosophie religieuses (Strasbourg) 50, 1970, 137-153.

SCHMUCKER, Josef: Wolfgang Cramers Widerlegung der Gottesbeweiskritik Kants. In: Archiv für Geschichte der Philosophie (Berlin/New York) 52, 1970, 287-301.

WAGNER, Hans: Kants Kritik des kosmologischen Gottesbeweises (Zu J. Schmucker: Das Problem der Kontingenz der Welt). In: Archiv für Geschichte der Philosophie (Berlin/New York) 52, 1970, 187-199.

WebB, Clement C. J.: Kant's Philosophy of Religion. New York 1970 [Reprint der Ausgabe Oxford 1926].

Wood, Allen W[illiam]: Kant's Moral Religion. Ithaca/ London 1970. Rezensionen: F. E. Wilson. In: Ethics (Chicago) 81, 1970, 79-85; D. Walsh. In: The Philosophical Quarterly (St. Andrews) 21, 1971, 75-76; W. E. Steinkraus. In: The Journal of the History of Philosophy (Berkeley, CA) 9, 1971, 516-518; E. Schmueli. In: Bibliographie de la Philosophie (Paris) 21, 1974, 270; R. Malter. In: Kant-Studien (Berlin) 65, 1974 , 334-339.

ZELDIN, Mary-Barbara: An Analysis of the Relation of the Summum Bonum to the Moral Law and the Postulate of the Existence of God (Summary). In: Akten des XIV. Internationalen Kongresses für Philosophie, Wien 2. bis 9. September 1968. Bd. V. Wien 1970, 533-534.

ZELDIN, Mary-Barbara: Principles of Reason, Degrees of Judgment, and Kant's Argument for the Existence of God. In: The Monist (La Salle) 54, 1970, 285-301. 


\section{1}

BURTON, Michael S.: The Role of Time in Kant's Metaphysics of Experience. Univ. Diss.: Claremont Graduate School 1971 [D.A.I., 32/05-A, p. 2739; O.N. 71296-57].

FruCHON, Pierre: «Problèmes Kantiens». Pour une théologie naturelle. In: Archives de Philosophie (Paris) 34, 1971, 177-206.

FUNKE, Gerhard: Der Weg zur ontologischen Kantinterpretation. Kritischer und metaphysischer, methodischer und historischer, systematischer und aporetischer, standpunktlicher und überstandpunktlicher Kant. Heinz Heimsoeths historischsystematische Interpretation der kritizistischen Kritik und Metaphysik. In: KantStudien (Berlin) 62, 1971, 446-466.

GALEAZZI, Umberto: Lideale trascendentale. In: Filosofia (Torino) 22, 1971, 427-441.

GIORDANO, Maria: La religione in Kant secondo un'opere recente. In: Sapienza (Napoli) 24, 1971, 105-108 [Zu: Lamacchia, Ada: La filosofia della religione in Kant. Bari 1969].

HARMS, Julius: Das kantische "pro me" und das theologische "pro nobis". In: Neue Zeitschrift für systematische Theologie und Religionsphilosophie (Berlin) 13, 1971, 351-362.

Heimsoeth, Heinz: Studien zur Philosophie Immanuel Kants. I.: Metaphysische Ursprünge und ontologische Grundlagen. Zweite, durchgesehene Auflage, Bonn 1971 [11956]. Rezensionen: R. Malter. In: Kant-Studien (Berlin) 63, 1972, 278-279.

ManZANO, Isidoro: Las dimensiones metafisicas de la persona, según Kant. In: Antonianum (Rom) 46, 1971, 443-485.

MarGolin, Jean-Claude: Kant critique de la métaphysique. In: Revue de Synthèse (Paris) 92, 1971, 96.

MARTY, François: Bulletin d'études kantiennes. Le problème métaphysique dans la philosophie de Kant. In: Archives de Philosophie (Paris) 34, 1971, 81-124.

METz, Wulf: Christologie bei Immanuel Kant. In: Theologische Zeitschrift (Basel) 27, $1971,325-346$.

Miller, George W.: Kant's First Edition Refutation of Dogmatic Idealism. In: Kant-Studien (Berlin) 62, 1971, 298-318.

OJZERMAN, T[eodor] I.: Transcendental'naja dualisti...eskaja metafizika I. Kanta [Die transzendentale dualistische Metaphysik Kants]. In: Ojzerman, T. I.: Glavnye filosofskie napravlenija [Die wichtigsten philosophischen Strömungen]. Moskva 1971, 210-223.

PalenCiA GOMEZ, José: El argumento ontológico de San Anselmo a Kant. Univ. Diss.: México (Universidad Nacional Autónoma de México) 1971.

PAOlinelli, Marco: Fisico-teologia e principio di ragion sufficiente. II. Kant: Della contingenza alla possibilità intrinseca. In: Rivista di Filosofia Neo-scolastica (Milano) 63, 1971, 295-348.

PaOlinelli, Marco: Fisico-teologia e principio di ragione sufficiente. Boyle, Maupertuis, Wolff, Kant. Milano 1971. Rezensionen: L. T. In: Bibliographie de la Philosophie (Paris) 
20, 1973, 345-346; A. Deregibus. In: Giornale di Metafisica (Genova) 28, 1973, 635638; W. Risse. In: Studia Leibnitiana (Stuttgart) 6, 1974, 298-300.

SOLOV'Ev, E[rich] Ju.: Relig. vera i nravstvennost' na filosofija Kanta [Religiöser Glaube und Sirtlichkeit in Kants Philosophie]. In: Nauka i religija [Wissenschaft und Religion]. Bd. 1. Moskva 1971, 22-28.

SOLOV'Ev, E[rich] Ju.: Znanie, vera i nravstvennost'. Kantovskaja postanovka voprosa o vzaimootno_enii nauki i nravstvennosti [Wissen, Glaube und Sittlichkeit. Die Kantische Fragestellung der Korrelation von Wissenschaft und Sittlichkeir]. In: Nauka i nravstvennost' [Wissenschaft und Sittlichkeit] (Moskva) 1971, 208-267.

Sullivan, William J.: Kant on the Existence of God in the Opus Postumum. In: The Modern Schoolman (Saint Louis) 48, 1971, 117-133.

TUSCHLING, Burkhard: Metaphysische und transzendentale Dynamik in Kants Opus postumum. Berlin 1971. Rezensionen: K. Hartmann. In: Philosophy and History (Tübingen) 5, 1972, 171-173; W. von Leyden. In: Mind 82, 1973, 293-294; L. Schäfer. In: Archiv für Geschichte der Philosophie (Berlin/New York) 56, 1974, 335339; A. Häußling. In: Kant-Studien (Berlin) 66, 1975, 366-372; E. Oeser. In: Wiener Jahrbuch für Philosophie 6, 1973, 432.

Vos, H[armen] de: Kant als theoloog. Baarn 1968. Rezensionen: K. Oedingen. In: KantStudien (Berlin) 62, 1971, 404-405.

Vos, H[armen] de: Kant en de godsdienst. In: Sonderheft von Wijsgerig Perspectief of Maatschappij en Wetenschap (Amsterdam) 1971, 199-207.

WAND, Bernard: Religious Concepts and Moral Theory: Luther and Kant. In: The Journal of the History of Philosophy (Berkeley, CA) 9, 1971, 329-348.

ZELDIN, Mary-Barbara: The Summum Bonum, the Moral Law, and the Existence of God. In: Kant-Studien (Berlin) 62, 1971, 43-54.

1972

ALQUIE, Ferdinand: Science et métaphysique chez Malebranche et chez Kant. In: Revue Philosophique de Louvain 70, 1972, 5-42.

DAVIS, Devra: Conceptualizations of Religion and Science in Some Writings of Emmanuel Kant and Auguste Comte. Univ. Diss.: University of Chicago 1972.

HiLl, Thomas E.: The Kingdom of Ends. In: Proceedings of the Third International Kant Congress Held at the University of Rochester. March 20-April 4, 1970. Hrsg. von Lewis White Beck. Dordrecht 1972, 307-315.

HINSKE, Norbert: Kants Begriff der Antithetik und seine Herkunft aus der protestantischen Kontroverstheologie des 17. und 18. Jahrhunderts. In: Archiv für Begriffsgeschichte (Bonn) 16, 1972, 48-59.

KNUDSEN, Harald: Gottesbeweise im Deutschen Idealismus. Die modaltheoretische Begründung des Absoluten, dargestellt an Kant, Hegel und Weiße. Berlin 1972. Rezensionen: J. Kopper. In: Kant-Studien (Berlin) 65, 1974, 224-226; W. Kern. In: 
Zeitschrift für katholische Theologie (Wien) 96, 1974, 133-135; W. Jaeschke. In: Hegel-Studien (Bonn) 10, 1975, 373-382; J. Splett. In: Theologie und Philosophie (Freiburg i.Br.) 50, 1975, 119-120; E. Simons. In: Philosophische Rundschau (Tübingen) 23, 1976, 146-148; G. Bleickert. In: Philosophy and History (Tübingen) $10,1977,24-27$.

LABERGE, Pierre: La physicothéologie de l'«Allgemeine Naturgeschichte und Theorie des Himmels» (1755). In: Revue Philosophique de Louvain 70, 1972, 541-572.

LangeraK, Edward A.: Orienting Oneself Rationally: Kant's Constructive Philosophy of Religion. Univ. Diss.: Princeton University 1972 [D.A.I., 33/05-A, p.2427; O.N. 72297-97].

MalTer, Rudolf: Kritizismus und Metaphysik. Zur Kantinterpretation Hinrich Knittermeyers. In: Kant-Studien (Berlin) 63, 1972, 86-100.

PANOU, Stavros: Zur Metaphysik des Ichs. In: Tijdschrift voor Filosofie (Leuven) 34, 1972, 489-499.

PLAT, Jan: Ethiek en godsdienst van Immanuel Kant tot Emmanuel Levinas. In: Algemeen Nederlands Tijdschrift voor Wijsbegeerte (Assen) 64, 1972, 15-25.

ROTENSTREICH, Nathan: Religion within Limits of Reason Alone and Religion of Reason. In: Year Book XVII of the Leo Baeck Institute (London) 1972, 179-187.

SCHMUKER, Josef: Joseph Moreaus Interpretation der Kantischen Gottesbeweiskritik in «Le Dieu des philosophes". In: Archiv für Geschichte der Philosophie (Berlin/New York) 54, 1972, 37-88.

SPAVENTA, Bertrando: Note sulla metafisica dopo Kant [Torino 1873]. In: Spaventa, Bertrando: Opere, vol. I. Firenze 1972, 525-529.

Travaglia, Sandro: Metafisica ed etica in Kant. Dagli scritti precritici alla Critica della ragion pura. Padova 1972.

\section{3}

Despland, Michel: Kant on History and Religion with a Translation of Kant's "On the Failure of All Attempted Philosophical Theodicies". Montreal - London 1973. Rezensionen: R. Malter. In: Kant-Studien (Berlin) 67, 1976, 243-246; H. S. Harris. In: Philosophy and Phenomenological Research (Buffalo) 36, 1976, 425-427; W. H. Walsh. In: Philosophical Books (Leicester) 16, 1975, 20-22; O. Reboul. In: Canadian Journal of Philosophy (Calgary/Edmonton) 6, 1976, 145-152.

DUPRE, Louise: The Cosmological Argument After Kant. In: International Journal for Philosophy of Religion (The Hague) 3, 1973, 131-145.

DÚSING, Klaus: Die Rezeption der kantischen Postulatenlehre in den frühen philosophischen Entwürfen Schellings und Hegels. In: Das älteste Systemprogramm. Studien zur Frühgeschichte des deutschen Idealismus. Hrsg. von Rüdiger BUBNER. Bonn 1973, 53-90 [Hegel-Studien. Beiheft 9]. 
EBBinghaus, Julius: Die Formeln des kategorischen Imperativs und die Ableitung inhaltlich bestimmter Pflichten. In: Kant. Zur Deutung seiner Theorie von Erkennen und Handeln. Hrsg. von Gerold PRAUSS. Köln 1973, 274-291.

FRAISSE, Jean-Claude: Téléologie et théologie selon Kant d'après la «Dissertation" de 1770 et la "Critique du Jugement". In: Revue de Métaphysique et de Morale (Paris) 78, 1973, 487-495.

GaLFAZZI, Umberto: Kant, la metafisica e lo scientismo. In: Rivista della Filosofia Neoscolastica (Milano) 65, 1973, 119-150.

GARCIA BELSUNCE, Eduardo: El pensamiento de Kant en 1762-1763: metafisica, ciencia y método. In: Cuadernos de Filosofia (Buenos Aires) 11, 1973, 357-369.

Heidegger, Martin: Kant und das Problem der Metaphysik. Vierte, erweiterte Auflage. Frankfurt a. M. 1973. Rezensionen: J. Kopper. In: Kant-Studien (Berlin) 65, 1974, 483.

HeidemanN, Ingeborg: Die Theorie der Theorien im Werk Gottfried Martins. Zur Stellung Kants in der aporetisch-dialektischen Metaphysik. In: Kant-Studien (Berlin) 64, 1973, 1-29.

Humphrey, Ted B.: The Historical and Conceptual Relations between Kant's Metaphysics of Space and Philosophy of Geometry. In: The Journal of the History of Philosophy (Berkeley, CA) 11, 1973, 483-512.

JONOY GARCIA-VIEDMA, José María: La "fe racional" y el "saber metafísico" en la filosofía crítica de Kant. Madrid 1973 [Univ. Diss.: Madrid 1973]. Rezensionen: F. Duque Pajuelo. In: Kant-Studien (Berlin) 69, 1978, 216-218.

LABERGE, Pierre: La théologie kantienne précritique. Ottawa 1973. Rezensionen: J. L. In: Bibliographie de la Philosophie (Paris) 21, 1974, 390-391; L. Guillermit. In: Revue Philosophique de la France et de l'Étranger (Paris) 99, 1974, 472-473; G. B. Sala. In: Theologie und Philosophie (Freiburg i.Br.) 50, 1975, 155-156; P. Corvez. In: Revue de Métaphysique et de Morale (Paris) 80, 1975, 101-102; O. Reboul. In: Philosophiques (Montréal) 1, 1974, 83-93; G. Lebrun. In: Dialogue (Montréal/ Kingston) 14, 1975. 686-693; W. H. Walsh. In: Canadian Journal of Philosophy (Calgary/ Edmonton) 4, 1975, 723-729; P.-Ph. Druet. In: Revue Philosophique de Louvain 74, 1976, 147-149.

LOEMKER, Leroy E.: The Metaphysical Status of Regulative Maxims in Leibniz and Kant. In: The Southern Journal of Philosophy (Memphis) 11, 1973, 141-147.

Nelson, Larry Kendall: Relation of Religious and Moral Discourse: A Kantian Argument in an Analytic Mode. Univ. Diss.: Yale University 1973 [D.A.I., 34/06-A, p. 3533; O.N. 73283-09].

Norburn, Greville: Kant's Philosophy of Religion: A Preface to Christology? In: Scottish Journal of Theology (London) 26, 1973, 431-448.

OAKES, Robert A.: Noumena, Phenomena, and God. In: International Journal for Philosophy of Religion (The Hague) 4, 1973, 30-38.

PICKEN, Stuart D. B.: The Meaning of Faith in the Thought of Kant. Univ. Diss.: Oxford 1973. 
RASCHKE, Carl Allan: Moral Action, God, and History in the Thought of Immanuel Kant. Univ. Diss.: Harvard University 1973.

SCHWYZER, Hubert: Thought and Realiry: the Metaphysics of Kant and Wittgenstein. In: The Philosophical Quarterly (St. Andrews) 23, 1973, 193-206.

SLUSZIEWICZ, Eugeniusz: Immanuel Kant a metafizyka dawnych Indii [Immanuel Kant und die Metaphysik des alten Indien]. In: Studia Filozoficzne (Warszawa) 89, 1973, 7-14.

ThIBAUD, E[mile]: De «être" à "ne pas être» il n'y a qu'un pas. (L'existence de Dieu dans la Critique de la raison pure). In: Annales de la Faculté des Lettres et Sciences Humaines de Nice 20, 1973, 115-131.

WHITE, David A.: The Metaphysics of Disinterestedness: Shaftesbury and Kant. In: Journal of Aesthetics and Art Criticism (Baltimore) 32, 1973, 239-248.

YONEDA, Shigeo: Über das Böse in der Religionslehre Kants - besonders aus moralischer Sicht betrachtet [japanisch]. In: The Hiroshima University Studies 32, 1973, 70-84.

Yovel, Yirmiahu: Kant und die Rehabilitation der Metaphysik [hebräisch]. Jerusalem 1973. Rezensionen: H. S. In: Bibliographie de la Philosophie (Paris) 22, 1975, 67.

YOVEL, Yirmiahu: Métaphysique et propositions mathématiques chez Kant. In: Archives de philosophie (Paris) 36, 1973, 239-266.

YOVEL, Yirmiahu: Bible Interpretation as Philosophical Praxis: A Study of Spinoza and Kant. In: The Journal of the History of Philosophy (Berkeley, CA) 11, 1973, 189-212.

ZuCKov, V[ladimir] A.: Gnoseologiceskoe soderzanie kantovskogo obosnovanija metafiziki, Avtoreferat dissertacii na soiskanie ucenoj stepeni kandidata filosofskich nauk [Der erkenntnistheoretische Inhalt der Kantischen Grundlegung der Metaphysik. Autoreferat zur Erlangung des wissenschaftlichen Grades eines Kandidaten der philosophischen Wissenschaften]. Moskva 1973 [31 S.].

1974

ARIEL, Robert Andrew: Theistic Proofs and Immanuel Kant. A Conflict Revisited. In: American Academy of Religion Journal (Tallahassee, FL) 42, 1974, 298-306.

BonveCCHIO, Claudio: Metafisica e ontologia in Kant. Per una analisi della "Critica della Ragion Puram. Pavia 1974. Rezensionen: K. Oedingen. In: Kant-Studien (Berlin) 67, 1976, 593-594.

BOROwSKI, Henryk: «Bezboznosc» filozofii Kanta w Ňwietle krytyki Miottiego [Die "Gottlosigkeit" der kantischen Philosophie im Lichte von Miottis Kritik]. In: Euhemer (Warszawa) 18, 1974, Nr. 3, 99-109.

BUROCKER, Jill: The Development of Kant's Metaphysics of Nature. Univ. Diss.: University of Chicago 1974.

CAMERON, Evan William: God, Kant, and the Transcendental Object. In: Akten des 4. Internationalen Kant-Kongresses Mainz. 6.-10. April 1974. Teil 1l.1: Sektionen. Hrsg. von Gerhard FUNKE. Berlin/ New York 1974, 347-355. 
CaPUTO, John D.: Kant's Refutation of the Cosmological Argument. In: Journal of the American Academy of Religion (Philadelphia, PA) 42, 1974, Nr. 4, 686-691.

CoviC Ante: Metafizika i revolucija u eti...koj artikulaciji [Metaphysik und Revolution in ethischer Interpretation]. In: Ideje (Beograd) 5, 1974, Nr. 6, 25-32. [Darin das Kapitel: Kant - mislilac revolucije / Kant - Denker der Revolution, 28-32.]

D'HONDT, U.: Geloofsveruitwendigung en geloofsgemeenschap en de godsdienstfilosofie van Kant. In: Miscellanea Albert Dondeyne. Godsdienstfilosofie. Philosophie de la religion. Bibliotheca Ephemeridum theologicarum Lovaniensum 35. Hrsg. von Albert DONDEYNE. Leuven 1974, 53-65.

DUBNICKA, Ján: Ku kantovej Metafyzike ...asu [Zu Kants Metaphysik der Zeit]. In: Filozofia (Bratislava) 29, 1974, 655-661.

ElKanA, Yehuda: Scientific and Metaphysical Problems: Euler and Kant. In: Methodological and Historical Essays in the Natural and Social Sciences. Hrsg. von Robert S. COHEN und Marx W. WARTOFSKY. Dordrecht/ Boston 1974, 277-305.

Evans, Charles Stephen: Subjective Justifications of Religious Belief: A Comparative Study of Kant, Kierkegaard, and James. Univ. Diss.: Yale University 1974 [D.A.I., 35/07-A, p. 4611; O.N. 75013-56].

FUEHRER, Mark Lawrence: The Development of Kant's Moral Theology (in the «Religion within the Limits of Reason Alonew). Univ. Diss.: University of Minnesota 1974 [D.A.I., 35/02-A, p. 1157; O.N. 74172-45].

FUNKE, Gerhard: Von der Aktualität Kants: Naturerfahrung und Freiheitsbewußtsein. In: Zeitschrift für Religions- und Geistesgeschichte (Köln) 26, 1974, 318-333.

GORSEN, Peter: Kants Transzendentalismus und Metaphysik im Kontext der ursprünglichen Apperzeption. In: Die Wirklichkeir des Unverständlichen. Professor Dr. med. Hemmo Müller-Saur zum 60. Geburtstag gewidmet. Hrsg. von Jan M. BROEKMAN und Günter HOFER. Den Haag 1974, 78-87.

GuLICK, Walter Brooks: Kant's Idea of Metaphysics: From Ontology through Empirical and Transempirical Systems to Authentic Existence. Univ. Diss.: Claremont Graduate School 1974 [D.A.I., 35/03-A, p. 1700; O.N. 74201-01].

HAYES, Patricia: An Analysis of Kant's Use of the Term 'Metaphysics.' Univ. Diss.: Georgetown University 1974 [D.A.I., 35/06-A, p. 3810; O.N. 74264-31].

KADOWAKI, Takuji: Dotoku to keiji jÇgaku [Moral und Metaphysik]. In: Riso (Tokyo) 1974, Nr. 498, 13-24 [Sondernummer: «Kant und unsere Zeit»].

KaLINOwSKI, Georges: La philosophie de S. Thomas d'Aquin face à la critique de la métaphysique par Kant, Nietzsche et Heidegger. In: San Tommaso e il pensiero moderno. Saggi. Roma 1974, 257-283.

KEIL, Günther: Kants "Kritik der reinen Vernunft" und der Gott der theoretischen Metaphysik. In: Neue Zeitschrift für systematische Theologie und Religionsphilosophie (Berlin) 16, 1974, 1-16. 
LABERGE, Pierre: Preuve physico-théologique et omnisuffisance divine. In: Akten des 4. Internationalen Kant-Kongresses Mainz. 6.-10. April 1974. Teil II.1: Sektionen. Hrsg. von Gerhard FunKE. Berlin/ New York 1974, 388-393.

LEHMANN, Gerhard: Zur Frage der Systematik in Kants Metaphysikvorlesungen. In: Akten des 4. Internationalen Kant-Kongresses Mainz. 6.-10. April 1974. Teil I: Kant-StudienSonderheft. Symposien. Hrsg. von Gerhard FUNKE und Joachim KOPPER. Berlin/ New York 1974, 140-154. Auch in: Ders.: Kants Tugenden. Neue Beiträge zur Geschichte und Interpretation der Philosophie Kants. Berlin/ New York 1980, 158-172.

LEVIN, Michael E.: Kant's Derivation of the Formula of Universal Law as an Ontological Argument. In: Kant-Studien (Berlin) 65, 1974, 50-66.

LIEPERT, Anita: Aufklärung und Religionskritik bei Kant. In: Deutsche Zeitschrift für Philosophie (Berlin) 22, 1974, 359-368.

LIEPERT, Anita: Die Metaphysik dialektisch «tractieren». Zur Rolle Kants in der sowjetischen Forschung. In: Forum (Berlin) 28, 1974, Nr. 9, 9.

MALTER, Rudolf: Intelligible Freiheit, Hang zum Bösen und moralische Bildung. Der Mainzer Theologe Felix Anton Blau und die Religionsphilosophie Immanuel Kants. In: Mainzer Zeitschrift 69, 1974, 127-134.

MALTER, Rudolf: Zur Kantliteratur 1970-1972. Neue Bücher zu Kants Rationaltheologie und Philosophie der Religion. In: Akten des 4. Internationalen Kant-Kongresses Mainz. 6.-10. April 1974. Teil I: Kant-Studien-Sonderheft. Symposien. Hrsg. von Gerhard FUNKE und Joachim KoPPER. Berlin/ New York 1974, 155-177.

Martin, Gottfried: Kant's Metaphysics and Theory of Science. Aus dem Deutschen übersetzt von P. G. Lucas. Manchester, Engl./ Westport, CT, 1974. [Nachdruck der Ausgabe von 1955.]

MiNESHIMA, Hideo: Kant ni okeru Rekishi to Shäkyo [Geschichte und Religion bei Kant]. In: Riso (Tokyo) 1974, Nr. 498, 25-35. [Sondernummer: "Kant und unsere Zeit».]

MiwataRI, Yukio: Der Weg zu Kants Religionsphilosophie (I) [japanisch]. In: The Hiroshima University Studies 33, 1974, 1-28.

NAVARro Cordón, Juan Manuel: Método y metafisica en el Kant precritico. In: Anales del Seminario de Metafisica (Madrid) 9, 1974, 75-122.

PavloviC, Branko: Kantova kritika metafizike [Kants Kritik der Metaphysik]. In: Theoria (Beograd) 18, 1974, 21-31.

PlAT, Jan: Symbolisme en analogie in onze kennis van God bij I. Kant. In: Miscellanea Albert Dondeyne. Godsdienstfilosofie. Philosophie de la religion. Bibliotheca Ephemeridum theologicarum Lovaniensum 35. Hrsg. von Albert DONDEYNE. Leuven 1974, 177-192.

Reboul, Olivier: La théologie kantienne précritique, par P. Laberge. In: Philosophiques (Montréal/Canada) 1, 1974, 83-93.

Revue de Métaphysique et de Morale (Paris), 79ª année, Nr. 4, 1974 [Sonderthema: Kant]. 
RoHATYN, Dennis A.: Kant's «Disproof» of God. In: Sophia (Geeling, Victoria/Australia) 13, 1974, 30-31.

SCHMUCKER, Josef: Die positiven Ansätze Kants zur Lösung des philosophischen Gottesproblems. In: Die Wirklichkeit Gottes. Gott in der Sprache heuriger Probleme. Hrsg. von Kurt KrenN. München/Wien 1974, 61-76.

SCHWEITZER, Albert: Die Religionsphilosophie Kants von der Kritik der reinen Vernunft bis zur Religion innerhalb der Grenzen der bloßen Vernunft. Hildesheim - New York 1974 [Nachdruck der Ausgabe Freiburg i. B./ Leipzig/ Tübingen 1899]. Rezensionen: R. Malter. In: Kant-Studien (Berlin) 66, 1975, 267-268.

THUM, Beda: Der kosmologische Gottesbeweis nach Kant und das Kontingenzargument der Metaphysik. In: Salzburger Jahrbuch für Philosophie (Salzburg) 17/18, 1973/74, 145-174.

WaTTE, Pierre: Structures philosophiques du péché originel. S. Augustin, S. Thomas, Kant. Vorwort von Paul Ricœur. Gembloux 1974. Rezensionen: M. Flick. In: Gregorianum (Roma) 56, 1975, 788-789; H. Jacobs. In: Nouvelle Revue Théologique (Tournai) 107, 1975, 965-969; M.-M. Labourdette. In: Revue Thomiste (Toulouse) 76, 1976, 461467; D. Bourel. In: Kant-Studien (Berlin) 69, 1978, 222-223.

1975

ALDONONDO, Carlos A.: El primer argumento de la exposición metafísica del concepto del tiempo en la Crítica de la razón pura. In: Sapienza (Napoli) 30, 1975, 273-282.

BiedermanN, Georg: Bemerkungen zum Religionsbegriff bei Kant. In: Wissenschaftliche Zeitschrift. Friedrich Schiller-Universität Jena 24, 1975, 209-220.

BRADley, Denis J. M.: Transcendental Critique and Realist Metaphysics. In: The Thomist (Washington, D. C.) 39, 1975, 631-667.

BYHOVSKIJ, B[ernard] E.: Religija pered sudom razuma [Die Religion vor dem Gericht der Vernunft]. In: Voprosy nau...nogo ateizma [Fragen des wissenschaftlichen Atheismus] (Moskva) 1975, Heft 17, 200-229.

COHEN, Hermann: Kants Begründung der Ethik nebst ihren Anwendungen auf Recht, Religion und Geschichte ['1910] [Auszug]. In: Materialien zu Kants Kritik der praktischen Vernunft. Hrsg. von Rüdiger BITTNER und Konrad CRAMER. Frankfurt a. M. 1975, 422-453.

FISCHER, Wolfgang: Die Möglichkeit der Kunst nach Kants Destruktion aller Metaphysik. In: Pädagogische Rundschau (Wuppertal) 29, 1975, 701-718.

FORSCHENER, Maximilian: Kants Dilemma einer Metaphysik des Willens. In: Philosophische Rundschau (Tübingen) 21, 1975, 117-129. [Zu: Hutchings (1972), Reboul (1971), Weisskopf (1970).]

FORSTER, Wolfgang: Zwischen "Metaphysik» und "praktischer Vernunft". Zur Auseinandersetzung mit der Kantinterpretation in der BRD. In: Zum Kantverständnis unserer Zeit. Beiträge marxistisch-leninistischer Kantforschung. Hrsg. von Hermann LEY, Peter RUBEN, Gottfried STIEHLER. Berlin 1975, 526-553. 
HERRING, Herbert: Leibniz and Kant on the Existence of God. In: Indian Philosophical Annual (Madras) 10, 1974/75, 173-182.

KASHER, Naomi: Kants Ethik und Leibowitz' Sicht der Religion [hebräisch]. In: Iyyun (Jerusalem) 26, 1975, 242-255.

KOPPER, Joachim: Kants Stellungnahme zum ontologischen Gottesbeweis in seinen Randbemerkungen zu Eberhards “Vorbereitungen zur natürlichen Theologie». In: Die Wirkungsgeschichte Anselms von Canterbury. Akten der ersten Internationalen Anselm-Tagung Bad Wimpfen - 13. bis 16. September 1970. I. Teil: Das Ontologische Argument in der Geschichte der Philosophie. Im Auftrag des Internationalen Komitees für Anselm-Studien hrsg. von Helmut Kohlenberger. Frankfurt a. M. 1975, 249-253 [Analecta Anselmiana IV/1].

LUTTTERFELDS, Wilhelm: Kants Metaphysik der subjektiven Zeit. In: Wissenschaft und Weltbild (Wien) 28, 1975, 137-151.

MacKInnon, D[onald] M.: Kant's Philosophy of Religion. In: Philosophy (London) 50, 1975, 131-144.

MAJER, Ulrich - STUHLMANN-LAEISZ, Rainer: Das Verhältnis von Mathematik und Metaphysik in Kants Theorie der Naturwissenschaft. In: Grazer Philosophische Studien (Amsterdam) 1, 1975, 165-188.

MALTER, Rudolf: Zeitgenössische Reaktionen auf Kants Religionsphilosophie. Eine Skizze zur Wirkungsgeschichte des Kantischen und des reformatorischen Denkens. In: bewußt sein. Gerhard Funke zu eigen. Hrsg. von Alexius J. BUCHER, Hermann DRÜE, Thomas M. SEEBOHM. Bonn 1975, 145-167.

MANCINI, Italo: Kant e la teologia. Assisi 1975.

MANCINI, Italo: Saggio bibliografico sul pensiero religioso di Kant. In: MANCINI, Italo: Kant e la teologia. Assisi 1975, 241-250.

MARTY, François: La naissance de la métaphysique chez Kant. Une étude sur la notion kantienne d'analogie. Thèse Lettres: Paris 1975.

OJZERMAN, Teodor I.: Immanuel Kant und die rationalistische Metaphysik des 17. Jahrhunderts. In: Deutsche Zeitschrift für Philosophie (Berlin) 23, 1975, 124-133.

PATON, Herbert James: Kant's Metaphysic of Experience [Auszug, in dt. Übers.]. In: Materialien zu Kants Kritik der reinen Vernunft. Hrsg. von Joachim KOPPER und Rudolf MALTER. Frankfurt a. M. 1975, 134-172.

RASCHKE, Carl A[llan]: Moral Action, God, and History in the Thought of Immanuel Kant. Tallahassee, 1975.

Revue de Métaphysique et de Morale (Lausanne). 80e année, Nr. 1, 1975 [Sonderheft Kant]; Nr. 2, 1975 [Teil-Sonderheft Kant].

Savcenko, A. I.: Kant i neopositivizm. Problema metafiziki [Kant und der Neupositivismus. Das Problem der Metaphysik.]. In: Kriti...eskie o...erki po filosofii Kanta, sbornik statej. Akademija nauk ukrainskij SSR. Institut Filosofii. Redkol.: M. A. Bulatov i dr. [Kritische Abhandlungen zur Philosophie Kants, Sammelband. Akademie der Wissenschaften der Ukrainischen SSR. Institut für Philosophie. Redaktionskollegium M. A. Bulatov u. a.]. Kiev 1975, 288-298. 
STEIGER, Lothar: Ontologisches oder kosmologisches Argument? Anselm zwischen Kant, Hegel und Barth. In: Die Wirkungsgeschichte Anselms von Canterbury. Akten der ersten Internationalen Anselm-Tagung Bad Wimpfen - 13. bis 16. September 1970. I. Teil: Das Ontologische Argument in der Geschichte der Philosophie. Im Auftrag des Internationalen Komitees für Anselm-Studien hrsg. von Helmut KOHLENBERGER. Frankfurt a. M. 1975, 317-322.

Stuhlmann-Laeisz, Rainer: Freges Auseinandersetzung mit der Auffassung von, "Existenz" als einem Prädikat der ersten Stufe und Kants Argumentation gegen den ontologischen Gottesbeweis. In: Frege und die moderne Grundlagenforschung. Symposion, gehalten in Bad Homburg im Dezember 1973. Hrsg. von Christian THIEL. Meisenheim am Glan 1975, 119-133.

Tonelli, Giorgio: Kant's Ethics As a Part of Metaphysics: A Possible Newtonian Suggestion? With Some Comments on Kant's "Dreams of a Seer". In: Philosophy and the Civilizing Arts. Essays Presented to Herbert W. Schneider. Hrsg. von Craig WaltoN and John P. ANTON. Athens, OH, 1975, 236-263.

TrillhaAs, Wolfgang: Kant und die Religion [Nachdr. aus: Allgemeines Sonntagsblatt, 14. April 1974]. In: Collegium Albertinum: Beiträge zum Immanuel Kant-Gedenkjahr 1974. Beiheft zum Rundbrief der Gemeinnützigen Gesellschaft Albertinum in Göttingen vom 30. Juni 1975. Göttingen 1975, 57-64.*

WAGNER, Hans: Moralität und Religion bei Kant. In: Zeitschrift für philosophische Forschung (Frankfurt a. M.) 29, 1975, 507-520.

WALSH, W[illiam] H[enry]: Critical Notice [zu: Pierre Laberge: La théologie kantienne précritique. Ottawa 1973]. In: Canadian Journal of Philosophy (Calgary/ Edmonton) 4, 1975, 723-729.

WALSH, W[illiam] H[enry]: Kant's Criticism of Metaphysics. Edinburgh 1975. Rezensionen: D. P. Dryer. In: Canadian Journal of Philosophy (Calgary) 7, 1977, 413-423; P. Guyer. In: The Philosophical Review (Ithaca, NY) 86, 1977, 264-270; A. Melnick. In: The Journal of Philosophy (New York) 74, 1977, 180-184; J. Vesey. In: Philosophy (London) 52, 1977, 109-111; N. C. In: The Review of Metaphysics (Washington) 31 1978, 494-495; D. Walford. In: Philosophical Books (Leicester) 17, 1976, 65-67; T. E. Wilkerson. In: Mind 85, 1976, 614-616; J. Kopper. In: Kant-Studien (Berlin) 69, 1978, 215-216.

WerkmeIster, William H.: Changes in Kant's Metaphysical Conception of Man. In: Idealistic Studies (Worcester, MA) 5, 1975, 97-107.

\section{6}

CRAIG, Peter Lewis: Kant and the Moral Interpretation of Religion. Univ. Diss.: Duke University 1976 [D.A.I., 37, p. 3712; O.N. 76277-72].

DEMPF, Alois: Die Metaphysik Immanuel Kants. In: Philosophisches Jahrbuch der Görresgesellschaft (München) 83, 1976, 120-132.

ERNST, Ursula: Der Gottesbegriff innerhalb der transzendentalen Ontologie Kants. Univ. Diss.: Wien 1976. 
FUNKE, Gerhard: Die Diskussion um die metaphysische Kantinterpretation. In: KantStudien (Berlin) 67, 1976, 409-424.

FUNKE, Gerhard: Die Wendung zur Metaphysik im Neukantianismus des 20. Jahrhunderts. In: Actes du Congrès d'Ottawa sur "Kant dans les traditions anglo-américaine et continentale» tenu du 10 au 14 octobre. Proceedings of the Ottawa Congress on «Kant in the AngloAmerican and Continental Tradition", Held October 10-14, 1974. Hrsg. von Pierre Laberge, FranHois DuCheSneAu, Bryan E. MORRISEY. Ottawa 1976, 36-76. Auch in: Ders.: Von der Aktualität Kants. Bonn 1979, 181-216.

HeIDEMANN, Ingeborg: Metaphysikgeschichte und Kantinterpretation im Werk Heinz Heimsoeths. In: Kant-Studien (Berlin) 67, 1976, 291-312.

HeizmanN, Winfried: Kants Kritik der spekulativen Theologie und Begriff moralischen Vernunftglaubens im katholischen Denken der späten Aufklärung. Göttingen 1976. Rezensionen: G. B. Sala. In: Theologie und Philosophie (Freiburg i.Br.) 54, 1979, 457459; K.-H. Weger. In: Theologische Revue (Münster) 74, 1978, 125-126.

KaUlBaCH, Friedrich: Kants Metaphysik der Natur. Weltidee und Prinzip der Handlung bei Kant. In: Zeitschrift für philosophische Forschung (Frankfurt a. M.) 30, 1976, 329-349.

KIM-LAN, Thai Thi: Die restriktive Funktion der Sinnlichkeit in Kants Kritik der rationalen Theologie mit besonderer Berücksichtigung der Kritik der reinen Vernunft. Univ. Diss.: München 1976.

KRAFT, Michael Allan: The Autonomy of Aesthetic Experience: The Implications of Kant's "Critique of Judgment" for Metaphysical Thought. Univ. Diss.: New School for Social Research 1976 [D.A.I., 37, p. 3695-A; O.N. 76280-41].

LEBRUN, Gérard: La troisème "Critique» ou la théologie retrouvée. In: Actes du Congrès d'Ottawa sur "Kant dans les traditions anglo-américaine et continentale» tenu du 10 au 14 octobre. Proceedings of the Ottawa Congress on "Kant in the Anglo-American and Continental Tradition", Held October 10-14, 1974. Hrsg. von Pierre LABERGE, FranHois DuChesneAU, Bryan E. MORRISEY. Ottawa 1976, 297-317.

LOTZSCH, Frieder: Vernunft und Religion im Denken Kants. Köln - Wien 1976. Rezensionen: A. Winter. In: Theologie und Philosophie (Freiburg i.Br.) 53, 1978, 283285.

LUTTERFELDS, Wilhelm: Das kategoriale Apriori des Erfahrungsfortschritts. Zur Kantischen Problematik metaphysischer Erfahrungsgrenzen. In: Von der Notwendigkeit der Philosophie in der Gegenwart. Festschrift für Karl Ulmer zum 60. Geburtstag. Hrsg. von Helmut KOHLENBERGER und Wilhelm LUTTERFELDS. Wien/ München 1976, 283-309.

MiCHALSON, Gordon E.: The Historical Dimensions of a Rational Faith: The Relation Between History and Religion in Kant's Philosophy. Univ. Diss.: Princeton University 1976 [D.A.I., 37, p. 2255-A; O.N. 76226-21].

Molinuevo, José Luis: La fundamentación kantiana de la metafísica según Heidegger. In Memoriam. In: Pensamiento (Madrid) 32, 1976, 259-279.

PATON, Herbert James: Kant's Metaphysic of Experience. A Commentary on the 1st Half of the Kritik der reinen Vernunft. I-II [1936]. Hassocks 1976.

QuaYYum, Abdul: The Idea of God and Divine Existence in Kant. In: The Pakistan Philosophical Journal (Lahore) 14, 1976, 1-33. 
SCHMUCKER, Josef: Zur Datierung der Reflexion 3716. Das Versagen der Wortstatistik in der Frage der Datierung der frühen Kantischen Reflexionen zur Metaphysik, aufgewiesen an einem exemplarischen Fall. In: Kant-Studien (Berlin) 67, 1976, 73-101.

SETH, Andrew: The Development from Kant to Hegel with Chapters on the Philosophy of Religion [London - Edinburgh 1882]. In: The Philosophy of Immanuel Kant. A Collection of Eleven of the Most Important Books on Kant's Philosophy, Reprinted in 14 Volumes. Hrsg. von Lewis White BECK. Repr. New York/ London 1976.

SMITH, Lanis Scott: Critical Observations on Whitehead's Approach to Speculative Metaphysics in the Light of Kant's Criticism. Univ. Diss.: Columbia University 1976 [D.A.I., 37, p. 4434-A; O.N. 76296-04].

SOLOV'EV [= Solowjow], E[rich] Ju.: Religiöser Glaube und Sittlichkeit in der Philosophie Kants. In: Revolution der Denkart oder Denkart der Revolution. Beiträge zur Philosophie Immanuel Kants. Hrsg. von Teodor I. OJZERMAN und Manfred BuHR. Berlin 1976, 122-134.

SyMOTIUK, Stefan: Problem z»a radykalnego w filozofii moralnej Kanta [Das Problem des radikalen Bösen in der Moralphilosophie I. Kants]. In: Dziedzictwo Kanta. Materia»y z Sesji kantowskiej [Kants Erbe. Kantische Materialien und Texte]. Hrsg. von Jan GAREWICZ. Warszawa 1976, 72-82.

THEAU, Jean: Critique kantienne et critique néo-positiviste de la métaphysique. In: Actes du Congrès d'Ottawa sur "Kant dans les traditions anglo-américaine et continentale" tenu du 10 au 14 octobre. Proceedings of the Ottawa Congress on "Kant in the AngloAmerican and Continental Tradition", Held October 10-14, 1974. Hrsg. von Pierre LaBerge, FranHois Duchesneau, Bryan E. Morrisey. Ottawa 1976, 321-329.

WaLSH, W[illiam] H[enry]: Kant and Metaphysics. In: Kant-Studien (Berlin) 67, 1976, 372-384.

WINTER, Alois: Theologische Hintergründe der Philosophie Kants. In: Theologie und Philosophie (Freiburg i.Br.) 51, 1976, 1-51.

\section{7}

ABramJAN, L[ev] A.: Logika i metafizika v koncepcii Kanta [Logik und Metaphysik in der Konzeption Kants]. In: Filosofija i metodologi...eskie voprosy nauki [Philosophie und methodologische Fragen der Wissenschaft]. Erevan 1977, 128-138.

BoROwSHI, Henryk: Kantowska krytyka dowodów na istnienie Boga [Kants Kritik der Gottesbeweise]. In: Annales Universitatis Mariae Curie-Sk»odowska (Lublin) Vol. II, 5, Sectio I, 1977, 63-80 [russische und englische Zusammenfassung S. 79, 80].

CASSIRER, Ernst: Kant y el problema de la metafísica. Observaciones a la interpretación de Kant de Martin Heidegger. Übersetzung: Ernesto Garzón Váldez. In: Ideas y Valores (Bogotá) 1977, Nr. 48/49, 105-129.

Charlesworth, Max: St. Thomas Aquinas and the Decline of the Kantian-Kierkegaardian Philosophy of Religion. In: Tommaso d'Aquino nel suo settimo centenario. Atti del Congresso internazionale Roma/ Napoli, 17-24 aprile 1974. Vol. VI: L'essere. Napoli $1977,50-60$. 
Coluins, James: Functions of Kant's Philosophy of Religion. In: The Monist (La Salle) 60, $1977,157-175$.

CrumbaCH, Karl-Heinz: Theologie in kritischer Offentlichkeit. Die Frage Kants an das kirchliche Christentum. München/ Mainz 1977. Rezensionen: P. Knauer. In: Theologie und Philosophie (Freiburg i.Br.) 53, 1978, 592-593.

FONTAINE, José: Profondeur personnelle et dimensions collectives du mal et du mensonge chez Rousseau et Kant. In: Revue Philosophique de Louvain 75, 1977, 612-623.

GODFREY, Joseph John: Hope and its Implications for Theism: A Systematic Analysis in Dialogue with Kant, Bloch, and Marcel. Univ. Diss.: University of Toronto 1977 [D.A.I., 39, p. 4334-A; O.N. 03296-36].

Gonzalez Santoyo, Luis Lorenzo: Comentarios sobre las pruebas de la existencia de Dios en Santo Tomás de Aquino y Kant. Univ. Diss.: México (Universidad Nacional Autónoma de México) 1977.

HAKAMIES, Ahti: Der sogenannte umoderne» Gottesbegriff und die Frage nach dem Dasein Gottes bei Immanuel Kant. In: Logik, Mathematik und Philosophie des Transzendenten. Festgabe für Uuno Saarnio zum achtzigsten Geburtstag. Unter Mitwirkung von Heinz Enders u. a. hrsg. von Ahti HAKAMIES. München/ Paderborn/ Wien 1977, 155-163.

Harrus, Errol E.: Kant's Refutation of the Ontological Proof. In: Philosophy (London) 52, $1977,90-92$.

HEGEL, Georg Friedrich Wilhelm: Faith and Knowledge (Kant, Jacobi, Fichte). Übersetzt von Walter Cerf und H. S. Harris. Albany 1977.

HeIDEGGer, Martin: La "Crítica de la razón pura" de Kant y la tarea de la fundamentación de la metafísica. Apéndice de la 4a edición de "Kant y el problema de la metafísica". Übersetzt von Guillermo Hoyos. In: Idéas y valores (Bogotá) 1977, Nr. 48/49, 83-85.

HoLZ, Harald: Philosophischer Glaube und Intersubjektivität. Zum Glaubensproblem bei I. Kant und K. Jaspers. In: Kant-Studien (Berlin) 68, 1977, 404-419.

LOTz, Johannes B.: A diferença ontológica em Kant, Hegel, Heidegger e Tomás de Aquino. In: Revista Portuguesa de Filosofia (Braga) 33, 1977, 21-36 und 270-284.

Malter, Rudolf: Die letzte überlieferte Metaphysik-Vorlesung Kants. Zur Wiederauffindung der «Bemerkungen über Metaphysik nach Baumgarthen, aus dem Vortrag des HE Prof Kant pro 1794/95". In: Kant-Studien (Berlin) 68, 1977, 464-467.

MALTER, Rudolf: Königsberger Schrift in Thorner Bibliothek. Zur Wiederauffindung der Vorlesung Kants über Metaphysik aus dem Wintersemester 1794/95. In: OPrBl, 26. November 1977.

ManNo, A. Giacomo: Scoto e Kant sul problema di dio. Un duello a distanza di secoli. Firenze 1977.

MARTI Fritz: Theological Epistemology in Augustine, Kant, and Schelling. In: The Modern Schoolman (Saint Louis) 55, 1977, 21-35.

Michalson, G[ordon] E.: The Role of History in Kant's Religious Thought. In: Anglican Theological Review (Evanston, IL) 59, 1977, 413-423. 
O'FARRELL, F[rancis]: Kant's Concern in Philosophy of Religion. In: Gregorianum (Roma) $58,1977,471-522$.

PInKERTON, R. J: Kant's Refutation of the Ontological Argument. In: Indian Philosophical Quarterly (Poona, India) 5, 1977, 19-38.

PIZZUTI, Giuseppe Maria: Teologia e metafisica. La radice kantiana della posizione di Karl Barth nella «Kirchliche Dogmatik». In: Filosofia (Torino) 28, 1977, 569-589.

Pomerlean, Wayne Paul: Perspectives on Faith and Reason: Studies in the Religious Philosophies of Kant, Hegel, and Kierkegaard. Univ. Diss.: Northwestern University 1977 [D.A.I., 38, p. 5531-A; O.N. 78007-43].

RENZ, Horst: Geschichtsgedanke und Christusfrage. Zur Christusanschauung Kants und deren Fortbildung durch Hegel im Hinblick auf die allgemeine Funktion neuzeitlicher Theologie. Göttingen 1977.

Saltzman, Judy Deane: Paul Natorp's Philosophy of Religion within the Marburg NeoKantian Tradition. Univ. Diss: University of California (Santa Barbara) 1977 [D.A.I., 38, p. 6780-A; O.N. 78070-30].

SCHÜTZ, Johann Georg: Der Individualitäts- und Sozietätscharakter der Reich-Gottes-Idee Immanuel Kants. Univ. Diss.: Passau 1977.

TEICHNER, Wilhelm: Das Land der Wahrheit ist eine Insel. Die Neubegründung der Metaphysik durch Kant. In: Prima Philosophia (Cuxhaven) 3, 1977 [1978], 275-290.

WINTER, Aloysius: Gebet und Gottesdienst bei Kant: nicht "Gunstwerbung», sondern "Form aller Handlungen». In: Theologie und Philosophie (Freiburg i.Br.) 52, 1977, 341-377.

1978

AlbreCHT, Michael: Kant und der Katholizismus. Zwei Neuerscheinungen zur deutschen Spätaufklärung. In: International Studies in Philosophy (Torino/ Atlanta) 10, 1978, 167-174.

BatTaglia, Felice: Saggio sul governo divino del mondo. In: Dio. Autori vari. Vorwort: A. Giacomo Manno. [Problemi di attualita 1; Hrsg. der Reihe: A. Giacomo Manno.] Bologna 1978, 271-303.

BIEDERMANN, Georg - LANGE, Erhard: Zur Religionskritik der klassischen Philosophie. Die Herausbildung der Grundzüge der Staats- und Rechtstheorie bei Kant, Fichte und Hegel. In: Deutsche Zeitschrift für Philosophie (Berlin) 26, 1978, 1262-1278.

CORTINA ORTS, Adela: La teología trascendental. El más elevado punto de vista de la filosofía trascendental kantiana. In: Anales del Seminario de Metafísica (Madrid) 13, 1978, 47-66.

Garofalo, M. R.: Kant tra pietismo e teologia riformata. In: Università degli Studi, Annali della Facoltà di Lettere (Bari) 21, 1978, 219-247.

GRANIER, Jean: Réflexions sur l'essence de la métaphysique. In: Revue de Métaphysique et de Morale (Paris) 83, 1978, 433-446. 
KOBZAR I. I.: Kritika filosofii religii Kanta [Kritik der Kantschen Religionsphilosophie]. Referat für den Grad «Kandidat der Wissenschaft». LGU, Leningrad 1978 [16 S.].

KÖRNER, Stephan: Zur immanenten und transzendentalen Metaphysik. In: Prima Philosophia (Cuxhaven) 4, 1978, 135-145.

KvisT, Hans-Olof: Zum Verhältnis von Wissen und Glauben in der kritischen Philosophie Immanuel Kants. Struktur- und Aufbauprobleme dieses Verhältnisses in der "Kritik der reinen Vernunft". Åbo 1978. Rezensionen: W. Steinbeck. In: Kant-Studien (Berlin) 71, $1980,372-373$.

LLANO CIFUENTES, Alejandro: Filosofía trascendental y filosofía analítica I. (Transformación de la metafísica.) In: Anuario Filosófico (Pamplona) 11, 1978, $\mathrm{Nr} .1,89-122$.

LOTZ, Johannes B.: Die ontologische Differenz in Kant, Hegel, Heidegger und Thomas von Aquin. In: Theologie und Philosophie (Freiburg i.Br.) 53, 1978, 1-26.

MALL, Ram Adhar: Gedanken zur Pflichtethik Kants und in der Bhagavadgita. In: Die Kribbe. Bonner Vierteljahresschrift für Literatur, Kunst und Wissenschaft. Herbst 1978, 36-44.

ManNo, Giacomo A.: Scoto e Kant sul problema di Dio. In: Dio. Problemi di Attualità. Colonna a cura di A. Giacomo MANNO. Bologna 1978, 41-92.

Mier Guttérrez, Milagros Manuela: Ciencia y metafisica en Kant. Univ. Diss.: México (Universidad Iberoamericana) 1978.

MILES, Murray Lewis: Logik und Metaphysik bei Kant. Zu Kants Lehre vom zwiefachen Gebrauch des Verstandes und der Vernunft. Frankfurt a. M. 1978. Rezensionen: P. Jaeger. In: Philosophischer Literaturanzeiger (Frankfurt a. M.) 32, 1979, 257-261; M. Meyer. In: Revue Internationale de Philosophie (Bruxelles) 33, 1979, 601.

Rotenstreich, Nathan: Die Verschiedenheit der Religionen. Judentum und Christentum in den Systemen Kants, Cohens und Rosenzweigs. In: Die Krise des Liberalismus zwischen den Weltkriegen. Hrsg. von Rudolf von THADDEN. Göttingen 1978, 171 192.

Theophanous, Andrew Charles: The Structure of Experience and the Foundation of Science. An Evaluation and Modern Application of Kant's Views on Metaphysics in its Relation to Science, as set out in the "Critique of Pure Reason" and the "Metaphysical Foundations of Modern Science». Univ. Diss.: University of Melbourne 1978.

WoOD, Allen W[illiam]: Kant's Rational Theology. Ithaca/ London 21978 [11970].

ZuCkov, V[ladimir] A.: Problema metafiziki u rannego Kanta: Istoki kriticizma [Das Problem der Metaphysik beim frühen Kant: die Ursprünge des Kritizismus]. In: Voprosy teorii poznanija v burnuaznoj filosofii XVIII-na....ala XIX vv. [Fragen der Erkenntnistheorie in der bürgerlichen Philosophie des 18. bis zum Anfang des 20. Jahrhunderts.]. Moskva 1978, $17-45$.

ANDERSEN, Svend: Ideal und Singularität. Über die Funktion des Gottesbegriffs in Kants theoretischer Philosophie. Univ. Diss.: Heidelberg 1979. 
BaL, Karol: Aufklärung und Religion bei Mendelssohn, Kant und dem jungen Hegel. In: Deutsche Zeitschrift für Philosophie (Berlin) 27, 1979, 1248-1257.

BAUM, Manfred - HORSTMANN, Rolf-P.: Metaphysikkritik und Erfahrungstheorie in Kants theoretischer Philosophie. In: Philosophische Rundschau (Tübingen) 26, 1979, 62-91.

BYRnE, Peter: Kant's Moral Proof of the Existence of God. In: Scottish Journal of Theology (Edinburgh) 32, 1979, 333-343.

Cornay, David B.: Kant and the Closure of the Epoch of the Metaphysics of Presence. In: The Southwestern Journal of Philosophy (Norman, OK) 10, 1979, 39-72.

CUEVA, M. A. - KaPRANOv, V[ladimir] A.: Kant i russkaja religioznaja filosofija v konce XIX - nacale XX vv. [Kant und die russische Religionsphilosophie am Ende des 19. und am Anfang des 20. Jahrhunderts]. In: Voprosy teoreticeskogo nasledija Immanuila Kanta. Mezvuzovskij Sbornik [Fragen des theoretischen Erbes Immanuel Kants. Interuniversitärer Sammelband]. Bd. 4. Kaliningrad 1979, 94-98.

EsjuKov, A. I.: Sootnosenie metafiziceskogo i dialekticeskogo v gnoseologii I. Kanta [Die Wechselbeziehung des Metaphysischen und des Dialektischen in der Erkenntnistheorie I. Kants]. Referat für den Grad «Kandidat der Wissenschaft». LGU, Leningrad 1979 [20 S.].

FISCHER, Norbert: Die Transzendenz in der Transzendentalphilosophie. Untersuchungen zur speziellen Metaphysik an Kants «"Kritik der reinen Vernunft». Bonn 1979. Rezensionen: L. Kreimendahl. In: Bibliographie de la Philosophie (Paris) 28, 1981, 276; G. B. Sala. In: Theologie und Philosophie (Freiburg i. Br.) 56, 1981, 130-131; W. Steinbeck. In: Kant-Studien (Berlin) 72, 1981, 114-116; W. Teichner. In: Zeitschrift für philosophische Forschung (Frankfurt a. M.) 34, 1981, 10-13.

Fotinis, A[thanasios] P.: The Logical and Ontological Status of Kant's Concept of the Noumenon and the Hegelian Interpretation. In: Philosophia (Athen') 8/9, 1978/79, 384-400.

Friedman, R. Z.: Kant's Third Copernican Revolution. The Transition From Morality to Religion. In: Laval Théologique et Philosophique (Québec) 35, 1979, 21-33.

FUNKE, Gerhard: Der Weg zur ontologischen Kantinterpretation [1971]. In: FUNKE, Gerhard: Von der Aktualität Kants. Bonn 1979, 217-237.

GamberUCCI, Roberto: Introduzione al problema del male radicale in Kant. In: Teoresi (Catania) 34, 1979, 361-370.

GIOVANNI, George di: Kant's Metaphysics of Nature and Schelling's "Ideas for a Philosophy of Nature». In: The Journal of the History of Philosophy (Berkeley, CA) 17, 1979, 197 215.

GREEN, Ronald M.: Religious Ritual: A Kantian Perspective. In: The Journal of Religious Ethics (Knoxville, TN) 14, 1979, 229-238.

Hartmann, Eduard von: Kants Erkenntnistheorie und Metaphysik in den vier Perioden ihrer Entwicklung. Aalen 1979. [Nachdruck der Ausgabe Leipzig 1894.]

HofFMANN, Michael W.: Kant's Theory of Freedom: A Metaphysical Inquiry. Washington 1979. 
Michalson, Gordon E.: The Historical Dimensions of a Rational Faith: The Role of History in Kant's Religious Thought. Washington 1979.

SINGH, Ram Lal: An Advaitic Emendation of Kant: A Study in Comperative Metaphysics. In: Indian Philosophical Quarterly (Poona) 6, 1979, 175-183.

STRIEWE, Horst: Reditio subiecti in se ipsum. Der Einfluß Hegels, Kants und Fichtes auf die Religionsphilosophie Karl Rahners. Univ. Diss.: Freiburg 1979.

TrEASH, Gordon: Kant's Ontological Argument. In: Kant, Immanuel. The Once Possible Basis for a Demonstration of the Existence of God. Übersetzung und Einleitung von Gordon Treash. [Zweisprachige Ausgabe.] New York 1979, 9-39.

GAMBERUCCI Roberto: Il problema del male radicale nella filosofia kantiana. In: Filosofia Oggi (Bologna) 3, 1980, 96-104.

HUBer, Herbert: Die Gottesidee bei Immanuel Kant. Erster Teil. In: Theologie und Philosophie (Freiburg i.Br.) 55, 1980, 1-43.

LAZAROFF, Allan: The Kantian Sublime: Aesthetic Judgment and Religious Feeling. In: Kant-Studien (Berlin) 71, 1980, 202-220.

PAVICEVIC, Vuko: Filozofija religije Immanuela Kanta [Immanuel Kants Philosophie der Religion]. In: Sociologija religije sa elementima filozofije religije [Soziologie der Religion mit den Elementen der Philosophie der Religion]. Beograd, BIGZ, 21980, 352-363.*

Petrov, N. N.: Kriti...eskij analiz «dokazatel'stva bytija Boga» v filosofii Kanta i Gegelja [Kritische Analyse der "Existenzbeweise Gottes» in der Philosophie Kants und Hegels]. In: Materialy nau.... konf. mol. u...enyh. Samarkand 1980, 86-104.

SASAO, Kumetaro: Prolegomena zur Bestimmung des Gottesbegriffes bei Kant. Hildesheim/ New York 1980. [Unveränderter reprogr. Nachdruck der Ausgabe Halle 1900.]

SCHMUCKER, Joseph: Die Ontotheologie des vorkritischen Kant. Berlin/ New York 1980 [KSEH 112]. Rezensionen: D. D[ahlstrom]. In: The Review of Metaphysics (Washington) 35, 1981, 163-165; J. M. Häußling. In: Wissenschaftlicher Literaturanzeiger (Freiburg) 19, 1980, 2.

SESSIONS, William Lad: Kant and Religious Belief. In: Kant-Studien (Berlin) 71, 1980, 455468.

STOKER, Wessel: De christelijke godsdienst in de filosofie van de Verlichting. Een vergelijkende studie over de geloofsverantwoording in het denken van Locke, de deïsten, Lessing en Kant. Assen 1980 (Proefschrift Amsterdam (Vrije Univ.) Godgeleerdheid, 1980].*

WAGNER, Hans: Kritische Philosophie. Systematische und historische Abhandlungen. Hrsg. von Karl BÄRTHLEIN und Werner Flach. Würzburg 1980; darin: Die vier großen Probleme Immanuel Kants: Wissen - Sittlichkeit - Recht - Religion, 290-301; Kants Kritik des kosmologischen Gottesbeweises, 320-328; Moralität und Religion bei Kant, $339-348$. 
WIEBE, Don: The Ambiguous Revolution: Kant on the Nature of Faith. In: Scottish Journal of Theology (Edinburgh) 6, 1980, 515-532.

\section{1}

BAKIRDJIAN DE HAHN, Silvia S.: Kant y Levinas: la imposibilidad teórica de la metafísica. In: Strómata (Buenos Aires) 37, 1981, 165-171.

BODOC, Alexandru: Kant und Radulescu-Motru. Eine Rekonstruktion der Metaphysik auf Grund des Kritizismus im zeitgenössischen rumänischen Denken. In: Akten des 5. Internationalen Kant-Kongresses Mainz 4.-8. April 1981. Teil I.2: Sektionen VIII-XIV. In Verbindung mit Manfred KLEINSCHEnIEder, Rudolf Malter, Gisela MUller hrsg. von Gerhard FUNKE. Bonn 1981, 937-943.

Borges, Anselmo: Deus na Crítica da Razão pura. In: Humanística e Teologia (Porto)2, $1981,249-275$.

CORTINA OrTS, Adela: Dios en la filosofía trascendental de Kant. Salamanca 1981. Rezensionen: A. Pintor-Ramos. In: Cuadernos Salamantinos de Filosofía (Salamanca) 9, 1982, 400-403.

CORTINA ORTS, Adela: El lugar de Dios en el sistema trascendental kantiano. In: Pensamiento (Madrid) 37, 1981, 401-416.

DE Broca I Tella, Salvador: La metafísica en Kant. In: Universitas Tarraconensis 3, 1981, Nr. 3, 18-20.

Gómez Caffarena, José: Fe racional y existencia de Dios. In: Revista de Filosofía (Madrid) [ser. 2] 4, 1981, Nr. 2, 179-198.

Darkus, Roy Lionel: The Persistence of Kant and Hegel as Theological Models; the Realm of Faith versus the Realm of Philosophy as the Grounding for the Autonomy of the Human Subject. Univ. Diss.: Montreal (Concordia University) 1981.

Esteves, Agustín V.: El mal radical en Kant. In: Quintas Jornadas Nacionales de Filosofia (Córdoba, Arg.) 1981, 133-141.*

FISCHER, Norbert: Gottes Sein und Sein als Position. Zum Resultat der Kantischen Metaphysikkritik. In: Akten des 5. Internationalen Kant-Kongresses Mainz 4.-8. April 1981. Teil I.2: Sektionen VIII-XIV. In Verbindung mit Manfred KLEINSCHENIEDER, Rudolf MALTER, Gisela MULlER hrsg. von Gerhard FUNKE. Bonn 1981, 720-736.

Hauser, Linus: G. C. Storrs theologische Rezeption der Kritik der reinen Vernunft, ein Gelenkpunkt für das Verständnis des Deutschen Idealismus. In: Akten des 5. Internationalen Kant-Kongresses Mainz 4.-8. April 1981. Teil I.2: Sektionen VIII-XIV. In Verbindung mit Manfred KLeINSCHENIEDER, Rudolf MALTER, Gisela MÜller hrsg. von Gerhard FUNKE. Bonn 1981, 909-918.

HiNTIKKA, Jaakko: Kant on Existence, Predication, and the Ontological Argument. In: Dialectica (Bienne) 35, 1981, 127-146.

Holz, Harald: Philosophische und theologische Antinomik bei Kant und Thomas von Aquin [1970]. In: Zur Kantforschung der Gegenwart. Hrsg. von Peter HeinTEL und Ludwig NAGL. Darmstadt 1981, 344-368. 
Horstmann, Rolf-Peter: The Metaphysical Deduction in Kant's Critique of Pure Reason. In: The Philosophical Forum (Boston) 13, 1981, 32-47 [Comment: Stephan Körner 48-50.]

IRIBARNE, Julia Valentina: La libertad en Kant. Alcances éticos y connotaciones metafísicas. Buenos Aires 1981.

KIENZLE, Bertram: Kants $\dot{K}$ ritik der rationalen Theologie. In: Akten des 5. Internationalen Kant-Kongresses Mainz 4.-8. April 1981. Teil I.1: Sektionen I-VII. In Verbindung mit Manfred Kleinschenieder, Rudolf Malter, Gisela MUller hrsg. von Gerhard FUNKE. Bonn 1981, 549-556.

KINACH-BRZOZOWSKA, Krystyna: Jana Sniadeckiego koncepcja «metafizyki nauk» i krytyka filozofii Kanta. W 150 rocznice smierci uczonego UJan Sniadeckis Konzeption der "Wissenschaftsmetaphysik" und Kritik der Kantischen Philosophie]. In: Studia Filozoficzne (Warszawa) 1981 (187), Nr. 6, 123-138.

KORNFEIN, Roger Eric: Kant and the Metaphysics of Reference. Univ. Diss.: Calgary 1981.

KRAFT, Michael: Thinking the Physico-Teleological Proof. In: International Journal for Philosophy of Religion (The Hague) 12, 1981, 65-74.

LENK, Hans: Kants soziomorphe Begründung des Gottespostulats. Zur Kritik an Kants moralischen Gottes-«Beweisen» und zur Rekonstruktion eines dritten "Beweis»Versuchs. In: Zweihundert Jahre Kritik der reinen Vernunft. Hrsg. von Joachim KOPPER und Wolfgang MARX. Hildesheim 1981, 51-63.

MaCANN, Christopher E.: Kant and the Foundations of Metaphysics. An Interpretative Transformation of Kant's Critical Philosophy. Heidelberg 1981.

MALTER, Rudolf: Der Ursprung der Metaphysik in der reinen Vernunft. Systematische Überlegungen zu Kants Ideenlehre. In: Zweihundert Jahre Kritik der reinen Vernunft. Hrsg. von Joachim Kopper und Wolfgang Marx. Hildesheim 1981, 169-210.

PANOVA, Elena: Immanuel Kant i "analiticnata metafisika», ili oste vednaj "vasmojna li e metafisikata kato nauka" [Immanuel Kant und "die analytische Metaphysik», oder noch einmal "Ist die Metaphysik als Wissenschaft möglich?»]. Sofija 1981.

PANOVA, Elena: Kantovata "kritika na cistija rasum" sa vasmojnostta na metafisikata kato nauka [Kants "Kritik der reinen Vernunft" in bezug auf die Möglichkeit der Metaphysik als Wissenschaft]. In: GodiÓnik na universiteta, filosofija $i$ istorija [Jahrbuch der Universität, Philosophie und Geschichte] (Sofija) 1981, 51-91.

PIERCE, D. Morgan: Kant's Metaphysical Deduction. The Role of Predication in the First Edition of the Critique of Pure Reason. Univ. Diss.: Heidelberg 1981.

RIET, Georges van: Religion et espérance chez Kant. In: Presença Filosófica (São Paulo) 7 , 1981, Nr. 2-3, 35-38.

RoDRfGUEs LuÑo, Ángel: Dios y la moral kantiana. In: Evangelizzazione e ateismo. Atti del Congressso Internazionale su Evangelizzazione e ateismo. Roma, 6-11 Ottobre 1980. Roma/ Brescia 1981, 671-684. 
RossI, Philip J.: Kant as a Christian Philosopher: Hope and the Symbols of Christian Faith. In: PhT 25, 1981, 24-33.

SALA, Giovanni P.: Kant und die Theologie der Hoffnung. Eine Auseinandersetzung mit R. Schaefflers Interpretation der kantischen Religionsphilosophie. In: Theologie und Philosophie (Freiburg i. Br.) 56, 1981, 92-110.

SCHAEFfLER, Richard: Kant als Philosoph der Hoffnung. Zu G. B. Salas Kritik an meiner Interpretation der kantischen Religionsphilosophie. In: Theologie und Philosophie (Freiburg i.Br.) 56, 1981, 244-258.

SCHROLL-FleisCHER, Niels: Der Gottesgedanke in der Philosophie Kants. Odense 1981. Rezensionen: W. Sreinbeck. In: Kant-Studien (Berlin) 75, 1984, 120-122.

Sherover, Charles M.: Experiential Time and the Religious Concern. In: Zygon (Chicago, IL) $16,1981,323-344$.

SiCHIROLlo, Livio: Fede e sapere. Giobbe e gli amici. Reflessioni in tema di filosofia, religione e filosofia della religione in Kant e Hegel. In: Hegel interprete di Kant. Hrsg. von Valerio VerRA. Napoli 1981, 219-266.

SOFFER, Walter: Kant and the Tutelage of God and Nature. In: The Thomist (Washington) 45, 1981, 26-40.

STIEEHLER, Gottfried: Kants Religionsbegriff als «ideologische Form». In: Philosophie und Religion. Beiträge zur Religionskritik der deutschen Klassik. Hrsg. von Erhard Lange. [Collegium philosophicum Jenense. 3. Sektion: Marxistisch-leninistische Philosophie der Friedrich-Schiller-Universität Jena.] Weimar 1981, 61-71.

STOKER, W[essel]: Kants visie op de betekenis van de godsgedachte voor kennis en wetenschap. In: Nederlands Theologisch Tijdschrift ('s-Gravenhage) 35, 1981, 210224.

TERAN DUtari, Julio: Conocimiento y tradición metafísica: estudios gnoseológicos: Bergson, Heidegger, Husserl, Hegel, Kant, Tomás de Aquino. Quito 1981.

Tном, Martina: Religionsbelebung oder Religionskritik bei Kant? In: Philosophie und Religion. Beiträge zur Religionskritik der deutschen Klassik. Hrsg. von Erhard LANGE. [Sektion Marxistisch-leninistische Philosophie der Friedrich-Schiller-Universität Jena.] Weimar 1981, 72-83. [Collegium philosophicum Jenense Heft 3.]

TORNERo, Emilio: Religion y filosofía en Al-Kind\$, Averroes y Kant. In: Al-Qantara (Madrid) 2, 1981, 89-128.

ZAZov, Dimitar: Kant $\mathrm{i}$ religijata [Kant und die Religion]. In: Ateistica Tribuna [Atheistische Tribüne] 1981, Nr. 5, 21-30.

\section{2}

Alfaro, Juan: De la cuestión del hombre a la cuestión de Dios: Kant, Feuerbach, Heidegger. In: Gregorianum (Roma) 63, 1982, 211-271.

ARANA CAÑEDo ARGUElles, Juan: Ciencia y metafísica en el Kant precrítico (1746-1764). Una contribución a la historia de las relaciones entre ciencia y filosofía en el siglo XVIII. 
Sevilla 1982. Rezensionen: M. Caimi. In: Kant-Studien (Berlin) 76, 1985, 219-221; N. Demé. In: Revue Philosophique de la France et de l'Étranger (Paris) 108, 1983, 128 f.; L. Martínez Gómez. In: Bibliographie de la Philosophie (Paris) 30, 1983, 96; C. D. Landázur. In: Anuario Filosófico (Pamplona) 16, 1983, 199-203; R. Rodriguez Aramayo. In: Revista de Filosofia (Madrid)6, 1983, 352-353.

BENEDIKT, Michael: Metaphysische Deduktion der Kategorien. In: Überlieferung und Aufgabe. Festschrift für Erich Heintel zum 70 . Geburtstag. Hrsg. von Herta NaglDocekal. Bd. 1. Wien 1982, 35-48.

BOCAROV, V. A.: Analiz tak nazyvaemogo ontologiceskogo dokazatel'stva bytija Boga i ego kritika Kantom [Die Analyse des sogenannten ontologischen Beweises der Existenz Gottes und dessen Kritik durch Kant]. In: Modal'nye i relevantnye logiki [Modale und relevante Logiken]. Moskva 1982, 47-54.

CAPUTO, John D.: Metaphysics, Finitude, and Kant's Illusion of Pure Practical Reason. In: Proceedings of the American Catholic Philosophical Association (Washington) 56, $1982,87-94$.

CASALS PONS, Jaume: Kant: Assaig per introduir en filosofia el concepte de magnitud negativa i Somnis d'un visionari explicats per somnis de la metafísica (comentari). In: Enrahonar (Barcelona) 1982, Nr. 4, 37-45.

CesA, Claudio: Morale e religione tra Kant e Fichte. In: Teoria (Pisa) 2, 1982, 3-20.

CroITORU, Rodica: Judecata Tntre estetic Ói metafizic. RelaOia propedeutic-metafizic| a Criticii facult|Oii de judecare a lui Kant cu sistemul Criticilor. [Das Urteil zwischen Ästhetik und Metaphysik. Die propädeutisch-metaphysische Relation von Kants Kritik der Urteilskraft für das Kritische System.] BucureÔti: Edit. OtiinÛificl Ói Enciclopedic|, 1982.

ESSLER, Wilhelm K.: Fundamentals of a Semi-Kantian Metaphysics of Knowledge. In: The Monist (La Salle) 65, 1982, 106-115.

FAHLBERG, Detlef: Metaphysikkritik in Kants transzendentaler Ästhetik. In: Kants «Kritik der reinen Vernunft» im philosophischen Meinungsstreit der Gegenwart. Hrsg. von Hans-Martin Gerlach und Sabine Mocek. Martin-Luther-Universität HalleWittenberg. Wissenschaftliche Beiträge 1982, Nr. 10, 183-187.

FLUGGE, Christian Wilhelm: Versuch einer historisch-kritischen Darstellung des bisherigen Einflusses der Kantischen Philosophie auf alle Zweige der wissenschaftlichen und praktischen Theologie. 2 Bde. in 1 Bd. Hildesheim 1982. [Nachdruck der Ausgabe 1796-1798.] Rezensionen: R. Malter. In: Kant-Studien (Berlin) 77, 1986, 385-386.

GERLACH, Hans-Martin: Kants Metaphysikkritik und ihre Wirkung in der spätbürgerlichen Philosophie. In: Kants "Kritik der reinen Vernunft" im philosophischen Meinungsstreit der Gegenwart. Hrsg. von Hans-Martin GERLACH und Sabine MOCEK. Martin-LutherUniversität Halle-Wittenberg. Wissenschaftliche Beiträge 1982, Nr. 10, 67-86.

Glouberman, Mark: Reason and Substance. The Kantian Metaphysics of Conceptual Positivism. In: Kant-Studien (Berlin) 73, 1982, 1-16.

InTERdonato, Francisco: Crítica de Kant a las pruebas de la existencia de Dios. In: Medellín (Medellín, Colombia) 8, 1982, Nr. 31, 361-386. 
MaITlAND, Jeffrey: An Ontology of Appreciation: Kant's Aesthetics and the Problem of Metaphysics. In: JBSPh 13, 1982, 45-68.

MÁSMELA, Carlos: Teoría kantiana del movimiento: una investigación sobre los principios metafísicos de la foronomía. Colombia 1982.

Oyanerer-Jara, P.: Kant: el problema del cambio en la Crítica de la razón pura. (Aproximación a la posibilidad de la metafísica, en Kant.) In: Atenea (Santiago de Chile) 445, 1982, 57-73.

RuU, Federico: El mundo del espejo. Crítica y metafísica en Kant. In: Episteme (Cáracas), Nov. Ser. 2, 1982, 85-117.

RossI, Philip J.: Moral Autonomy, Divine Transcendence, and Human Destiny: Kant's Doctrine of Hope as a Philosophical Foundation for Christian Ethics. In: The Thomist (Washington) 46, 1982, 441-458.

RosSI, Philip J.: Kant's Doctrine of Hope: Reason's Interest and the Things of Faith. In: The New Scholasticism (Washingon) 56, 1982, 228-238.

Schalow, Frank: The Problem of Religious Discourse for Critical Philosophy. In: Dialogue (Kingston, Ont.) 25, 1982, 1-6.

SCHURR, Adolf: «Von der Unmöglichkeit eines ontologischen Beweises vom Dasein Gottes.» Zur "Widerlegung" des ontologischen Gottesbeweises bei Kant. In: L'héritage de Kant. Mélanges philosophiques offerts au P. Marcel Regnier. Paris 1982, 81-93.

SHEN QINSGSONG: Metaphysik. (Wichtige Abschnitte in der Geschichte der westlichen Metaphysik). - Die Einführung des Subjekts und Kants Transzendentalphilosophie. 4 Tle. [chinesisch]. In: Zhexue Yu Wenhua, Nr. 9 bis 12, 1982.*

VINCETN, G.: Onto-Théologie et théologie morale selon Kant. In: Revue d'Histoire et de Philosophie Religieuse (Strasbourg) 62, 1982, 239-250.

VLADUTESCU, Gheorghe: Comentariu la o critic/a argumentului ontologic [Kommentar zu einer Kritik des ontologischen Arguments]. In: Immanuel Kant. 200 de ani de la apariÛia Criticii RaÛiunii Pure. Studii. Hrsg. von Alexandru BOBOC u. a. BucureÓti 1982, 172-179.

\section{3}

ANDERSEN, Svend: Ideal und Singularität. Über die Funktion des Gottesbegriffs in Kants theoretischer Philosophie. Berlin 1983 [KSEH 116]. Rezensionen: A. Philonenko. In: Revue de Métaphysique et de Morale (Paris) 89, 1984, 561; G. 13. Sala. In: Theologie und Philosophie (Freiburg i.Br.) 59, 1984, 448-451.

BeuTEL, August Wilhelm: Die Beugung der reinen Vernunft zur Religion. Frankfurt a. M./ Bern 1983.

Borges, Anselmo: Kant e a questão de Deus. In: Humanistica e Teologia (Porto) 4, 1983, 281-319.

Carrillo Castillo, Lucy: Ciencia y metafísica a la luz del esquematismo de Kant. In: Universitas Philosophica (Bogotá) 1, 1983, Nr. 1, 11-24. 
Ferreira Jamie M.: Kant's Postulate: The Postulate or the Existence of God? In: KantStudien (Berlin) 74, 1983, 75-80.

GuAN ZIYIN: Kants humanistisches Verständnis von Religion [chinesisch]. In: Donghai Xuebao, Nr. 6, 1983.*

HAUSER, Linus: Religion als Prinzip und Faktum. Das Verhältnis von konkreter Subjektivität und Prinzipientheorie in Kants Religions- und Geschichtsphilosophie. Frankfurt a. M./ Bern 1983. Rezensionen: W. Steinbeck. In: Kant-Studien (Berlin) 75 , 1984, 241-244; Information Philosophie (Lörrach) 1985, Nr. 5, 54-55.

HÖFfE, Otfried: La révolution kantienne de la théologie philosophique. In: Paradigmes de théologie philosophique, publié sous la direction de Otfried Höffe et Ruedi Imbach en - hommage Marie-Dominique Philippe. Fribourg 1983, 143-164.

Hu HONGWEN: Metaphysik und Kants Philosophie. 2 Tle. [chinesisch]. In: Wenyi Fuxing, Nr. 7, 1983.*

Hund, William B.: The Sublime and God in Kant's «Critique of Judgment». In: The New Scholasticism (Washingon) 57, 1983, 42-70.

JUESTEN, Wilhelm: Ontotheologie und Gottesbeweiskritik bei Kant. Univ. Diss.: Bonn 1983.

KVIST, Hans-Olof: Das radikale Böse bei Immanuel Kant. In: Göttinger Orientforschungen. 1. Reihe: Syriaca. Bd. 24, 1983, 237-288.

LUK, J[ohn] C.: The Ambiguity of Kantian Faith. In: Scottish Journal of Theology (London) 36, 1983, 339-346.

MAMEDOV, A. K.: Kritika Kantom metafizičeskih pritjazanii hristianskoj teologii [Kants Kritik der metaphysischen Ansprüche der christlichen Theologie]. In: Aktual'nye problemy ateisti...eskogo vospitanija i kritika religioznoj ideologii [Aktuelle Probleme der atheistischen Erziehung und Kritik der religiösen Ideologie]. Moskva 1983, 35-39.

MANDT, A. J.: The Inconceivability of Kant's Transcendental Subject. An Impasse in Kant's Metaphysics. In: International Philosophical Quarterly (New York) 23, 1983, 13-34.

Michelini, Dorando J.: Kant y el problema del mal radical. In: Revista de Filosofía de la Universidad de Río IV (Córdoba) 1983, 95-109.

NARSKIJ, I[gor'] S[ergeevi...]: Kant i religija [Kant und die Religion]. In: Kantovskij Sbornik (Kaliningrad) 8, 1983, 3-12.

PetruzZelus, Nicola: Equivoci teologici di Kant. In: Sapienza (Napoli) 36, 1983, 129-136.

SALLIS, John: Die Krisis der Vernunft. Metaphysik und Spiel der Einbildungskraft. Übersetzr von Gisela Shaw. Hamburg 1983. Rezensionen: P. Jaeger. In: Philosophischer Literaturanzeiger (Frankfurt a. M.) 37, 1984, 370-372.

SCHMUCKER, Josef: Kants vorkritische Kritik der Gottesbeweise. Ein Schlüssel zur Interpretation des theologischen Hauptstücks der transzendentalen Dialektik der Kritik der reinen Vernunft. Mainz/ Wiesbaden 1983. Rezensionen: H. Wagner. In: KantStudien (Berlin) 75, 1984, 239-241; G. B. Sala. In: Theologie und Philosophie (Freiburg i.Br.) 59, 1984, 434-447; K. Bärthlein. In: Philosophischer Literaturanzeiger (Frankfurt a. M.) 38, 1985, 118-125. 
Torrevejano [PARRA], Mercedes: Razón y metafísica en Kant. Sentido de la dialéctica trascendental como crítica de la metafísica. Madrid 1983. Rezensionen: Tomás Cacho. In: Bibliographie de la Philosophie (Paris) 31, 1984, 309.

VAN KIRK, Carol Anne: Kant's Science of Metaphysics. Univ. Diss.: Toronto 1983.

WAGNER, Hans: Morality and Religion in Kant. Übersetzt von Dennis Schmidt. In: Contemporary German Philosophy (University Park) 3, 1983, 75-88.

WEINERT, F.: Ways of Criticising Metaphysics: Kant and Wittgenstein. In: Kant-Studien (Berlin) 74, 1983, 412-436.

WIKE Victoria S.: Metaphysical Foundations of Morality in Kant. In: The Journal of Value Inquiry (Geneseo/The Hague) 17, 1983, 225-234.

\section{4}

AdRIAANSE, Hendrik J[ohan]: Het moreel godsbewijs, in het bijzonder bij Kant. In: Wijsgerig Perspectief op Maatschappij en Wetenschap (Amsterdam) 24, 1983/84, 173 180.

CORTINA, Adela: Die Auflösung des religiösen Gottesbegriffs im Opus postumum Kants. In: Kant-Studien (Berlin) 75, 1984, 280-293.

Evans, Joseph Claude: The Metaphysics of Transcendental Subjectivity. Descartes, Kant and W. Sellars. Amsterdam 1984. Rezensionen: W. Sauer. In: Kant-Studien (Berlin) 77, 1986, 503-506.

Frankerberger, Horst: Kant und die Frage nach der göttlichen Allgenügsamkeit. Zur transzendentalen Wende in der philosophischen Gotteslehre. Frankfurt a. M./ Bern/ New York/ Nancy 1984.

GiLl, Jerry H.: Kant, Analogy, and Natural Theology. In: International Journal for the Philosophy of Religion (Dordrecht) 16, 1984, 19-28.

GretiĆ, Goran: Kant i ontoteologija [Kant und die Ontotheologie]. In: Godisnjak za povijest filozofije (Zagreb) 192, 1984; Kant, 58-72.

Horstmann, Rolf Peter: Die metaphysische Deduktion in Kants «Kritik der reinen Vernunft». In: Probleme der "Kritik def reinen Vernunft". Kant-Tagung in Marburg 1981. Hrsg. von Burkhard Tuschling. Berlin/ New York 1984, 15-33.

Kantian Ethical Thought. A Curricular Report and Annoted Bibliography Based on an NEH Summer Institute Exploring the Moral, Political, and Religious Views of Immanuel Kant. Tallahassee 1984.

KASIN, V. V. - SMELEV, V. D.: «Prosvescennyj» protestantizm «Kritiki ...istogo razuma» [Der «aufgeklärte» Protestantismus der "Kritik der reinen Vernunft»]. In: Kritika cistogo razuma Kanta i sovremennost' [Kants Kritik der reinen Vernunft und die Gegenwart]. Hrsg. von V[alentin] A. STENJBERG e. a. Riga 1984, 200-205.

MamedOV, A. K.: Kriticeskij analiz filosofii religii Immanuila Kanta [Eine kritische Analyse der Religionsphilosophie I. Kants]. Referat für den Grad «Kandidat der Wissenschaft". MGU. Moskva 1984 [21 S.]. 
ManCINI, Italo: Kant e la teologia. In: Kant e due secoli della "Critica". Hrsg. von Giuseppe MiCHELli und Giovanni SANTINELlo. Brescia 1984, 23-55.

NARSIJ, I[gor'] S[ergeevič]: OtnoÓenie Kanta k osnovnym religioznym problemam [Die Beziehung Kants zu grundlegenden religiösen Problemen]. In: Kritika ...istoga razuma Kanta i sovremennost' [Kants Kritik der reinen Vernunft und die Gegenwart]. Hrsg. von V[alentin] A. STENJBERG e. a. Riga 1984, 205-214.

OJZERMAN, T[eodor] I.: Transcendental'naja dualisti...eskaja metafizika I. Kanta [Die transzendentale dualistische Metaphysik Kants]. In: Ojzerman, T. I.: Glavnye filosofskie napravlenija [Die wichtigsten philosophischen Strömungen]. Moskva 21984, 166-174. [11971]

OlivieR, Paul: Métaphysique et religion. Kant, Hegel, Heidegger. Études. In: Recherches des Sciences Religieuses (Paris) 72, 1984, 219-242.

PORTER, Lindsay: The Quirks and Turns in the Eighth Paragraph of Kant's Chapter on the Ontological Argument. In: Indian Journal of Philosophy (Poona) 11, 1984, 309-332.

PALQUIST, Stephen R.: Faith as Kant's Key to the Justification of Transcendental Reflection. In: The Heythrop Journal (Oxford) 25, 1984, 442-455.

QuinN, Philipp L.: Original Sin, Radical Evil, and Moral Identity. In: Faith and Philosophy (Wilmory, KY) 1, 1984, 188-202.

ReVILLA GuZMÁ, Carmen G.: Intuición y metafísica: anotaciones a la crítica de Bergson a Kant. In: Anales del Seminario de Metafísica (Madrid) 19, 1984, 195-213.

RossI, Philip J.: Autonomy and Community: The Social Character of Kant's „Moral Faith». In: The Modern Schoolman (St. Louis, MS) 61, 1984, 169-186.

Toguolo, Antonio: La teologia. Un possibile consenso tra Tommaso d'Aquino e Kant. In: Kant a due secoli della "Critica". Hrsg. von Giuseppe Michell und Giovanni SANTINELLO. Brescia 1984, 283-294.

TRIGG, Roger: Sin and Freedom. In: Religious Studies (London) 20, 1984, 191-202.

Venturelli, Domenico: Critica delle prove di Dio e teologia autentica in Kant. In: Syncrisis (Genova) 1984, 84-133.

WAGNER, Hans: Kants affirmative Metaphysik von Dingen an sich. In: Kant a due secoli della "Critica». Hrsg. von Giuseppe MiCHELli und Giovanni SANTINello. Brescia 1984, 181-191.

WINTER Aloysius: Seele als Problem in der Transzendentalphilosophie Kants unter besonderer Berücksichtigung des Paralogismuskapitels. In: Seele. Ihre Wirklichkeit, ihr Verhältnis zum Leib und zur menschlichen Person. Hrsg. von K.KREMER. Leiden/ Köln 1984, 100-168.

WUNDT, Max: Kant als Metaphysiker. Ein Beitrag zur Geschichte der deutschen Philosophie im 18. Jahrhundert. Hildesheim 1984. [Nachdruck der Ausgabe Stuttgart 1924.]

ZELAZNY, Mirosmaw: Metafizyka czasu i wiecznosci w pismach teleogiczno-etycznych Immanuela Kanta [Die Metaphysik der Zeit und der Ewigkeit in Kants theologischethischen Schriften]. In: Studia Filozoficzne (Warszawa) 1984, Nr. 11/12, 37-53. 


\section{5}

ANDREEVA, I[skra] S[tepanova]: Sovremennye teologi i religiovedy o filosofii Kanta [Gegenwartstheologen und Religionsforscher über Kants Philosophie]. In: Kantovskij Sbornik (Kaliningrad) 10, 1985, 67-83.

CABRERA [Álvarez], Julio: Posibilidad del lenguaje metafísico (Del programa kantiano del 1783 al moderno apriorismo pluralista). In: Revista Latinoamericana de Filosofía (Birmingham, AL/ Buenos Aires) 11, 1985, 27-45.

CARVAJAL CORDÓN, Julián: Kant y la fundamentación del discurso de la metafísica. In: Anales del Seminario de Metafísica (Madrid) 20, 1985, 47-79.

Colın, Pierre: L'affirmation éthique du sujet moral. Kant et le rationalisme moral. In: Éthique, religion et foi. Hrsg. von Joseph Doré [Le point théologique 43]. Paris 1985, $39-57$.

DEGGAU, Hans-Georg: Die Architektonik der praktischen Philosophie Kants. Moral Religion - Recht - Geschichte. In: Archiv für Rechts- und Sozialphilosophie (Stuttgart) 71, 1985, 319-342.

GEYER, Carl-Friedrich: Marginalien zum Thema "Transzendentalphilosophie und Theologien. In: Franziskanische Studien (Werl) 65, 1985, 334-350

HECKMANN, Heinz-Dieter: Kant und die Ich-Metaphysik. Metakritische Überlegungen zum Paralogismus-Kapitel der Kritik der reinen Vernunft. In: Kant-Studien (Berlin) 76, $1985,385-404$.

HEEMST J. R. van: “... wie man die Freiheit retten kann.» Het kantiaanse vrijheidsbegrip als een dogmatische steen des aanstoots. In: Nederlands Theologisch Tijdschrift (Wageningen) 39, 1985, 128-137.

HOFFE, Otfried: Introduction à la philosophie pratique de Kant. La morale, le droit et la religion. Übersetzt von François Rüegg und Stéphane Gillioz. Albeuve, Suisse 1985. Rezensionen: J. Radrizzani. In: Revue de Théologie et de Philosophie (Lausanne) 36, 1986, 429-430; S. Goyard-Fabre. In: Revue de Métaphysique et de Morale (Paris) 92 , 1987, 133; A.-M. Roviello. In: Revue Internationale de Philosophie (Bruxelles) 42, 1988, 383-386.

HONNEFELDER, Ludger: Transzendent oder transzendental: Über die Möglichkeit von Metaphysik. In: Philosophisches Jahrbuch der Görresgesellschaft (München) 92, 1985, 273-290.

KuEHN, Manfred: Kant's Transcendental Deduction of God's Existence as a Postulate of Pure Practical Reason. In: Kant-Studien (Berlin) 76, 1985, 152-169.

LOPEZ HERnÁNDEZ, José: Reflexiones sobre la metafísica de Kant. In: Anales de Filosofía (Murcia) 1985, 81-97.

MCGoldricK, P. M.: The Metaphysical Exposition: An Analysis of the Concept of Space. In: Kant-Studien (Berlin) 76, 1985, 257-275.

MCKenZIE, David E.: Kant, a Moral Criterion, and Religious Pluralism. In: American Journal of Theology and Philosophy (West Lafayette, IN) 6, 1985, 47-56. 
Miller, Robert Ramsay: The Law of Love. A Revised Kantian Approach to Morality and Religion. Univ. Diss.: Monash University 1985.

MOHR, Georg: Objektivität und Selbstbewußtsein. 1. Teil: Zur neueren Kritik und Rekonstruktion von Kants metaphysischer und transzendentaler Deduktion der Kategorien. In: Philosophischer Literaturanzeiger (Frankfurt a. M.) 38, 1935, 271-287 [Zu: Probleme der Kritik der reinen Vernunft 1984; Hoppe 1983; Körsgen 1984; Röttges 1981].

MUNK, Hans H.: Der Freiburger Moraltheologe Ferdinand Geminian Wanker (1758-1824) und Immanuel Kant. Historisch-vergleichende Studie unter Berücksichtigung weiteren philosophisch-theologischen Gedankenguts der Spätaufklärung. Düsseldorf 1985.

O'ConNor, Daniel: Good and Evil Disposition. In: Kant-Studien (Berlin) 76, 1985, 288302.

Pesquero Franco, Encarnación: Kant y la reforma del saber metafísico. In: Anales del Seminario de Metafísica (Madrid) 20, 1985, 81-111.

PICHT, Georg: Kants Religionsphilosophie. Mit einer Einführung von Enno Rudolph. Stuttgart 1985. Rezensionen: U. Hinke-Dörnemann. In: Bibliographie de la Philosophie (Paris) 33, 1986, 446-447; J. M. Odero. In: Scripta Theologica 19, 1987, 971.

RODRfGUez ARAMAYO, Roberto: La filosofía kantiana de la historia. ¿Otra versión de la teología moral? In: Revista de Filosofia (Madrid) [2. Ser.] 8, 1985, 21-40

SEIFERT, Josef: Kant und Brentano gegen Anselm und Descartes. Reflexionen über das ontologische Argument. In: Theologia (Athen) 26, 1985, 878-905.

SEIFERT, Josef: Kant y Brentano contra Anselmo y Descartes. Reflexiones sobre el argumento ontológico. In: Thémata (Sevilla) 2, 1985, 129-147.

WAGNER, Falk: Aspekte der Rezeption Kantischer Metaphysik-Kritik in der evangelischen Theologie des 19. und 20. Jahrhunderts. In: Neue Zeitschrift für systematische Theologie und Religionsphilosophie (Berlin/ New York) 27, 1985, 25-41.

WINTER, Alois: Der Gottesbeweis aus praktischer Vernunft. Das Argument Kants und seine Tragfähigkeit vor dem Hintergrund der Vernunftkritik. In: Um die Möglichkeit oder Unmöglichkeit natürlicher Gotteserkenntnis heute. Hrsg. von Klaus Kremer. Leiden $1985,109-178$.

\section{6}

BAUM, Hermann: Zum funktionalen Interesse philosophischer Reflexionen über das Phänomen Religion bei Descartes, Kant und Schleiermacher. In: Neue Zeitschrift für systematische Theologie und Religionsphilosophie (Berlin/ New York) 28, 1986, 14-28.

BECK, Lewis White: Kant on Faith and Reason. In: The Time's Literary Supplement, 20. Juni 1986.

BEISSWENGER, Heidrun: Vernunft und Gotterkennen bei Immanuel Kant und Mathilde Ludendorff. In: Mensch und Maß (Pähl) 26, 1986, 913-921.

BENEDIKT Michael: Hauptaspekte der Metaphysik und ihre Infragestellung in der österreichischen Philosophie. Philosophische Botschaft an C. F. Stäudlin und die 
Baronesse von Herbert. In: Die Aufgaben der Philosophie in der Gegenwart. Akten des 10. Internationalen Wittgenstein-Symposiums 18. bis 25. August 1985 . Kirchberg am Wechsel. Hrsg. von Werner LeINFELlNER und Franz M. WUKETIS. Wien 1986, 316324.

BOROwSKI, Henryk: Kantowska filozofia religii [Kantische Religionsphilosophie]. Warszawa 1986.

BUCHDAHL Gerd: Metaphysical and Internal Realism. The Relations Between Ontology and Methodology in Kant's Philosophy of Science. In: Logic, Methodology and Philosophy of Science. VII. Proceedings of the Seventh International Congress of Logic, Methodology and Philosophy of Science. Hrsg. von Ruth BARCAN Marcus. Salzburg/ Amsterdam 1986, 623-641.

BUTTS, Robert Earl: Kant's Philosophy of Science: The Transition from Metaphysics to Science. In: Proceedings of the 1984 Biennial Meeting of the Philosophy of Science Association (PSA). Vol. 2. Hrsg. von Peter D. ASQUITH und Philip KITCHER. East Lansing 1986, 685-705.

BUTTS, Robert Earl: Kant's Quest for a Method for Metaphysics. In: Kant's Philosophy of Physical Science. Hrsg. von Robert E.BuTTS. Dordrecht u. a. 1986, 1-22.

BUTTS, Robert Earl: The Methodological Structure of Kant's Metaphysics of Science. In: Kant's Philosophy of Physical Science. Hrsg. von Robert E. BUTTS. Dordrecht u. a. 1986, 163-199.

Carvalho Calmon, Ubirajara: $\mathrm{O}$ argumento ontológico em Kant e a la. prima via da demonstração de Deus em S. Tomás. In: Revista Brasileira de Filosofia (São Paulo) 35, $1986,22-42$.

CASTRO, Edgardo: El conocimiento trascendental de Dios y la metafísica de la naturaleza. In: Sapienza (Napoli) 41, 1986, 167-180.

Deustch, Eliot: A Metaphysical Grounding for Natural Reverence: East - West. In: Environmental Ethics (Athens, GA) 8, 1986, 293-299.

EsPosito, Costantino: Ragione critica e problema di Dio. Appunti sulla filosofia di Kant. In: Il Nuovo Areopago 5, 1986, 111-126.

FISCHER, Norbert: Vom Nutzen der Metaphysikkritik. Kants Stellungnahme zu den «Einwürfen wider Sittlichkeit und Religion.» In: Trierer Theologische Zeitschrift 95, $1986,13-27$.

Friedman, R. Z.: Hypocrisis and the Highest Good: Hegel on Kant's Transition from Moraliry to Religion. In: The Journal of the History of Philosophy (Berkeley, CA) 24, $1986,503-522$.

FRIEDMAN, R. Z.: Kant and Kierkegaard: The Limits of Reason and the Cunning of Faith. In: International Journal for Philosophy of Religion (Dordrecht) 19, 1986, 3-22.

HEINRICH, Richard: Kants Erfahrungsraum. Metaphysischer Ursprung und kritische Entwicklung. Freiburg 1986. Rezensionen: U. Hinke-Dörnemann. In: Bibliographie de la Philosophie (Paris) 34, 1987, 319; V. Pittioni. In: Philosophy and History (Tübingen) $21,1988,9 \mathrm{f}$. 
HINTIKKA, Jaakko: Kant on Existence, Predication, and the Ontological Argument. In: The Logic of Being. Hrsg. von J. Hintikka und Simo Knuutrila. Dordrecht 1986, 249-268.

HÖFFE, Otfried: Introduction à la philosophie pratique de Kant. La morale et la religion. Albeuve 1986.

KopPers, Rita: Zum Begriff des Bösen bei Kant. Pfaffenweiler 1986.

KorsgaARD, Christine M.: The Right to Lie: Kant on Dealing With Evil. In: Philosophy and Public Affairs (Lawrence, NJ) 15, 1986, 325-349.

KOWALCZYK, Stanis»aw: Idea Boga w pismach I. Kanta [Die Idee von Gott in Kants Briefen]. In: Studia Philosophiae Christianae (Warschau) 22, 1986, 41-69.

MarCelli, Miroslav: Kant und die Metaphysik. In: Univerzita Komenskeho Filozofickà fakulta: Zbornik Philosophica (Bratislava) 23, 1986, 317-341.

PISCIONE, Enrico: Kant nell'interpretazione metafisico-religioso di Piero Martinetti. In: La tradizione kantiana in Italia. Hrsg. von der Università di Messina, Istituto di Filosofia "Adelchi attisani», Istituto di Filosofia «Galvano delle Volpe», Società Filosofica Italiana. Messina 1986, 571-580.

QI GuOxIONG: Kant über die Freiheit des Willens und das moralisch Gute und Böse [chinesisch]. In: Mingehuan Xuebao Nr. 3, 1986.*

Quinn, Philipp L.: Christian Atonement and Kantian Justification. In: Faith and Philosophy (Wilmore, KY) 3, 1986, 440-462.

Ribeiro Do SANTOS, Leonel: Immanuel Kant. Os progressos da Metafísica. In: Filosofia (Lisboa) 3, 1986, 131-137.

Rodrfguez Aramayo, Roberto: Postulado/Hipótesis. Las dos facetas del dios kantiano. In: Pensamiento (Madrid) 42, 1986, 235-244.

SCHÚssler, Ingeborg: Éthique et Théologie dans la Critique de la Faculté de Juger de Kant. In: Revue de Théologie et de Philosophie (Lausanne) 36, 1986, 337-372.

SoKoL, Moshe Z.: The Autonomy of Reason: Revealed Morality and Jewish Law. In: Religious Studies (New York) 22, 1986, 423-437.

ViCENTE ARReGUI, Gemma: El terremoto de Lisboa y el problema del mal en Kant. In: Thémata (Sevilla) 1986, Nr. 3, 141-152.

WEISSBERG, Liliane: "Catarcticon» und der schöne Wahn. Kants "Träume eines Geistersehers, erläutert durch Träume der Metaphysik». In: Poetica (München) 18, 1986, 96-116.

YANG CHENGHONG: Kants Theologie und ihr Übergang zwischen zwei großen Gebieten [chinesisch]. In: Kangde Heigeer Yanjiu, Bd. 2, Nr. 7, 1986.*

ZELAZNY, Miros»aw: Metafizyka czasu i wiecznosci jako filozofia czlowieka w idealizmie niemieckim (od Kanta do Nietzschego) [Die Metaphysik der Zeit und der Ewigkeit als Philosophie des Menschen im Deutschen Idealismus (Von Kant zu Nietzsche)]. Torun 1986. 
ANDREEVA, I[skra] S[tepanova]: Teologija i religiovedenie [Theologie und Religionswissenschaft]. In: Filosofija Kanta i sovremenyj idealizm [Die Philosophie Kants und der moderne Idealismus]. Hrsg. von I[skra] S[tepanova] Andreeva und B[oris] T. Grigor'jan. Einführung von I. S. Andreeva (3-13). Moskva 1987, 71-89.

ANDRJUSENKo, M. T.: Kant i Peirce: edinstvo i razlicie $\mathrm{v}$ otnosenii $\mathrm{k}$ poznavatel'nomu statusu very [Kant und Peirce. Gemeinsames und Verschiedenes in ihrer Auffassung des erkenntnismäßigen Status des Glaubens]. In: Kantovskij Sbornik (Kaliningrad) 12, 1987, 107-114.

CONSTANTE, Alberto: La repetición de la fundamentación kantiana de la metafísica. In: Teoría. Jornadas kantianas. Commemoración del bicentenario de la Crítica de la razón pura. 3, 3. Universidad Nacional Autónoma de México, Facultad de Filosofia y Letras. 1982-1987, 249-259.

FAGGIOTTO, Pietro: Recherche sur la métaphysique kantienne de l'analogie. In: Revue Thomiste (Toulouse) 87, 1987, 85-92.

FalKENBURG, Brigitte: Die Form der Materie. Zur Metaphysik der Natur bei Kant und Hegel. Frankfurt a. M. 1987. Rezensionen: O. Depré. In: Revue Philosophique de Louvain 86, 1988, 408 f.; R. Breil. In: Philosophischer Literaturanzeiger (Frankfurt a. M.) 41, 1988, 13-17; G. Di Giovanni. In: Kant-Studien (Berlin) 80, 1989, 226-228.

FURGER, Franz: Transzendentale Theologie der Praxis. Die Bedeutung Kants in der aktuellen moraltheologischen Diskussion. In: Auf der Suche nach dem verborgenen Gott. Zur theologischen Relevanz neuzeitlichen Denkens. Hrsg. von Alois HALDER, Klaus KIENZLER und Joseph MOLLER. Düsseldorf 1987, 97-115.

GONZALEZ, Juliana: Kant y la metafísica de lo trascendente a lo trascendental. In: Teoría. Jornadas kantianas. Commemoración del bicentenario de la Crítica de la razón pura. 3, 3. Universidad Nacional Autónoma de México, Facultad de Filosofía y Letras. 19821987, 283-289.

GUZMÁ, G.: Kant y el problema de la metafísica de Heidegger. In: Franciscanum (Bogotá) $29,1987,89-100$.

HALDER, Alois: Hoffnung im transzendentalen Verständnis. In: Auf der Suche nach dem verborgenen Gott. Zur theologischen Relevanz neuzeitlichen Denkens. Hrsg. von Alois HALDER, Klaus KIENZLER und Joseph MÚller. Düsseldorf 1987, 106-115.

KÜHN, Rolf: Vorstellung und Religion. Zur Christologie als Theorie realer Freiheit und verwirklichter Geschichte [zu: Renz 1977, s. Nr. ${ }^{*}$ ]. In: Teresianum/Ephemerides Carmeliticae (Roma) 38, 1987, fasc. I, 51-75.

MAMEDOV, A. K.: Filosofija religija Kanta [Die Religionsphilosophie Kants]. In: Religii mira [Religionen der Welt]. Moskva 1987, 170-192.

MARTINEZ MARTINEZ, José A.: Libertad, alma y Dios en la "Crítica de la razón pura». In: Pensamiento (Madrid) 43, 1987, 425-445.

Michalson, Gordon E.: The Inscrutability of Moral Evil in Kant. In: The Thomist (Washington) 22, 1987, 179-194. 
MiCHEL, Karl-Heinz: Immanuel Kant und die Frage nach der Erkennbarkeit Gottes. Eine kritische Untersuchung der "Transzendentalen Ästhetik» in der "Kritik der reinen Vernunft" und ihrer theologischen Konsequenzen. Wuppertal 1987.

MODEL, Anselm: Metaphysik und reflektierende Urteilskraft bei Kant. Untersuchungen zur Transformierung der Leibnizschen Monadenlehre in der "Kritik der Urteilskraft". Frankfurt 1987. Rezensionen: U. Hinke-Dörnemann. In: Bibliographie de la Philosophie (Paris) 36, 1989, 104-105.

MORRISON, Roy D.: Einstein on Kant, Religion, Science, and Methodological Unity. In: Einstein and the Humanities. Hrsg. von Dennis P. Ryan. New York 1987, 47-57.

MurPHY, Jeffrie G.: Kantian Autonomy and Divine Commands. In: Faith and Philosophy (Wilmore, KY) 4, 1987, 276-281.

NiCOLOSI, Salvatore: Logica e ontologia in Kant: forme del ragionamento e problemi della metafisica. In: Aquinas (Roma) 30, 1987, 307-330.

PALENCIA, José Ignacio: Kant y la metafísica. Crítica, práctica, objetividad y objetivación. In: Teoría. Jornadas kantianas. Commemoración del bicentenario de la Crítica de la razón pura. 3, 3. Universidad Nacional Autónoma de México, Facultad de Filosofía y Letras. 1982-1987, 271-281.

REARDON, Bernard M. G.: Kant as Philosophical Theologian. Basingstoke 1987.

REMEZOV , I. I.: Kritika sovremmenyh metafiziceskih interpretacij filosofii I. Kanta [Kritik der heutigen metaphysischen Interpretationen der Philosophie I. Kants]. Referat für den Grad "Kandidat der Wissenschaft". AN SSSR, In-t filosofii. Moskva 1987 [23 S.].

Rotenstreich, Nathan: Can There Be a Religion of Reason? In: Hegel-Studien (Bonn) 22, 1987, 89-110.

SalA, Giovanni B.: Kant. In: Argumente für Gott. Gort-Denker von der Antike bis zur Gegenwart. Ein Autoren-Lexikon. Hrsg. von Karl-Heinz Weger unter Mitarbeit von Klemens Bossong. Freiburg 1987, 188-194.

SCHAEFLER, Richard: Logisches Widerspruchsverbot und theologisches Paradox. Überlegungen zur Weiterentwicklung der transzendentalen Dialekrik. In: Theologie und Philosophie (Freiburg i.Br.) 62, 1987, 321-351.

STEFANOV, Ivan S.: Transcendentalnata filosofija i metafizikata: ot Kant do neokantianstvoto [Die Transzendentalphilosophie und die Metaphysik: von Kant bis zum Neukantianismus, Zusammenfassung in Russisch und Deutsch: 235-237]. Sofija 1987.

VerWeYen, Hansjürgen: Kants Gottespostulat und das Problem sinnlosen Leidens. In: Theologie und Philosophie (Freiburg i.Br.) 62, 1987, 580-587.

VicENTE ARRegui, Gemma: Dios y hombre en el Kant precrítico. Sevilla 1987.

VullLemin Jules: Physique et métaphysiques Kantiennes. Paris 21987.

WasChKIES, Hans-Joachim: Physik und Physikotheologie des jungen Kant. Die Vorgeschichte seiner Allgemeinen Naturgeschichte und Theorie des Himmels. Amsterdam 1987.

WATSON, Stephen: Regulations: Kant and Derrida at the End of Metaphysics. In: Deconstructing and Philosophy. Hrsg. von John Sallis. Chicago 1987, 71-86. 
WEINER, David: Prudential Ethics and Moral Faith: Why Ronald Green is not a Kantian. In: Idealistic Studies (Worcester, MA) 17, 1987, 149-160.

WINTER, Alois: Transzendentale Theologie der Erkenntnis. Ansärze zur theologischen Rezeption der Kantschen Vernunftkritik. In: Auf der Suche nach dem verborgenen Gott. Zur theologischen Relevanz neuzeitlichen Denkens. Hrsg. von Alois HALDER, Klaus KIENZLER und Joseph MOLLLER. Düsseldorf 1987, 68-96.

YANG ZUHAN: Versuch über die Bedeutung von Kants Ausführungen über das radikale Böse in der menschlichen Natur [chinesisch]. In: Ehu Nr. 2, 1987.*

YANG ZUHAN: Vorwort zu «Buddhismus und Kants Moralphilosophie» [chinesisch]. In: Ehu Nr. 3, 1987.*

BEANBLOSSSOM, Ronald E.: Kant's Quarrel with Reid: The Role of Metaphysics. In: History of Philosophy Quarterly (Bowling Green, OH) 5, 1988, 53-62.

BellunI, Ornella: Edward Caird interprete di Kant: Dal trascendentale formale verso l'idea dell'assoluto come unità del reale. In: Questioni di Etica e Metafisica. [Quaderni dell'Istituto di Filosofia 6, hrsg. vom Istituto di Filosofia (Perugia).] Napoli 1988, 6386.

CARPI, Orlando: E. Kant: dalla critica alla metafisica della moralità. Bologna 1988.

CASTAÑEDA, Hector-Néri: Metaphysical Internalism, Selves, and the Invisible Noumenon (A Frego-Kantian Reflection on Descartes' Cogito). In: Midwest Studies in Philosophy (Minneapolis, MN) 12, 1988, 129-144.

ChIEREghin, Franco: La metafisica come scienza e esperienza del limite. Relazione simbolica e autoterminazione pratica secondo Kant. In: Verifiche (Trento) 17, 1988, 81 106.

Del Barco Collazos, José Luis: La metafísica postulativa kantiana. Antinomfa y postulados prácticos. In: Estudios Filosóficos (Valladolid) 37, 1988, 53-100.

FAN JINXIN: Eine Klarstellung zur Kantischen Lehre von Wissen und Glauben [chinesisch]. In: Changsha Shuidian Shiyuan Xuebao Nr. 2, 1988.*

FISCHER, Norbert: Der formale Grund der bösen Tat. Das Problem der moralischen Zurechnung in der praktischen Philosophie Kants. In: Zeitschrift für philosophische Forschung (Frankfurt a. M.) 42, 1988, 18-44.

HaN, Jakyoung: Transzendentalphilosophie als Ontologie. Kants Selbstinterpretation der "Kritik der reinen Vernunft" und "Kritik der praktischen Vernunft" in seiner Schrift: "Welches sind die wirklichen Fortschritte, die die Metaphysik seit Leibnizens und Wolff's Zeiten in Deutschland gemacht hat?" Würzburg 1988. Rezensionen: K. Konhardt. In: Kant-Studien (Berlin) 86, 1995, 461-465.

Kerman, Deborah: The Role of God in Kant's Ethical Theory. Univ. Diss.: Stanford University 1988.

KONHART, Klaus: Die Unbegreiflichkeit der Freiheit. Überlegungen zu Kants Lehre vom Bösen. In: Zeitschrift für philosophische Forschung (Frankfurt a. M.) 42, 1988, 397-416. 
KREIMENDAHL, Lothar: Kants Kolleg über Rationaltheologie. Fragment einer bislang unbekannten Vorlesungsnachschrift. In: Kant-Studien (Berlin) 79, 1988, 318-328.

LANGE, Horst: Kants Modus ponens. Überlegungen und Vorschläge zu einer analytischen Rekonstruktion von Kants Metaphysik der Erfahrung. Würzburg 1988.

MaLTER, Rudolf: Kant. In: Theologische Realenzyklopädie, Bd. XVII. Berlin 1988, 570 581.

Marcucci, Silvestro: Neopositivismo, filosofia trascendentale e metafisica. In: Studi kantiani Bd. III: Aspetti teoretici e pratici del «kantismo", oggi. Lucca 1988, 35-59.

MECKENSTOCK, Günter: Deterministische Ethik und kritische Theologie. Die Auseinandersetzung des frühen Schleiermacher mit Kant und Spinoza. Berlin 1988.

MEYer, Michel: Science et métaphysique chez Kant. Paris 1988. Rezensionen: R. Theis. In: Revue Internationale de Philosophie (Bruxelles) 42, 1988, 386-391; L. Baumann. In: Kant-Studien (Berlin) 83, 1992, 111-114; A. Stanguennec. In: Revue Philosophique de la France et de l'Étranger (Paris) 121, 1996, 422.

Milz, Bernhard: Dialektik der Vernunft in ihrem praktischen Gebrauch und Religionsphilosophie bei Kant. In: Theologie und Philosophie (Freiburg i.Br.) 63, $1988,481-518$.

MOORS, Martin: Kants transcendentaal idealisme van fenomenen. Status quaestionis voor en transcendentale theologie. In: Tijdschrift voor Filosofie (Leuven) 50, 1988, 82-129.

OLIVA, R.: Kant e Freud - Metafísica e Metapsicologia. In: Educação e Filosofia (Uberlândia, Brazil) 2, 1988, Nr. 4, 99-107.

REARDON, Bernard M. G.: Kant as Philosophical Theologian. London 1988.

ReISINGer, Marion: Schlußlogik und Metaphysik bei Kant. Univ. Diss.: Köln 1988.

Rosenfield, Denis L.: Do mal. Para introduzir em filosofia o conceito de mal (Kant, Schelling, Hegel). Ins Portugiesische übersetzt von Marco Zingano. Porto Alegre 1988.

ROSENFIELD, Denis L.: Natureza humana e mal radical em Kant. Ins Portugiesische übersetzt von N. de Mendonça. In: Análise (Lisboa) 1988, Nr. 9, 111-125.

SALA, Giovanni B.: Kant. In: Religionskritik von der Aufklärung bis zur Gegenwart. Autoren-Lexikon von Adorno bis Witrgenstein. Hrsg. von Karl-Heinz Weger. Freiburg 41988.

SCHULTE, Christoph: radikal böse: die Karriere des Bösen von Kant bis Nietzsche. München 1988. Rezensionen: U. J. Wenzel. In: Kant-Studien (Berlin) 84, 1993, 231-233.

SIlvA, Franklin Leopoldo: A metafísica na Crítica da razão pura. In: Trans/Form/Ação (Marilia, Brazil) 11, 1988, 1-11.

SÖDER, Rigo: Rezension zu Georg Pichts «Kants Religionsphilosophie» [dt. Text mit chinesischer Zusammenfassung von Zhu Zhenglin]. In: Deguo Zhexue (Beijing) 5, Nr. $5,1988 .^{*}$

Song Bingyan: Kants Philosophie aus der Sicht des Gottesbegriffs [chinesisch]. In: Shanxi Daxue Xuebao Nr. 4, 1988.* 
STANGUENNEC, André: L'anthropologie contemporaine et la critique kantienne de la métaphysique. In: Revue de l'Enseignement Philosophique (Paris) 38, 1987/88, 24-29.

VeTÄ, Miklós: Le mal radical selon Kant. In: Le Mal et la maladie de Maître Eckhart à Thomas Bernhard. Études réunies par Jean-Marie Paul. Nancy 1988, 55-61.

Vossenkuhl, Wilhelm: The Paradox in Kant's Rational Religion. In: Proceedings of the Aristotelian Society (London) 88, 1987/88, 179-192.

ZÖLLER, Günter: Kant on the Generation of Metaphysical Knowledge. In: Kant. Analysen - Probleme - Kritik. Hrsg. von Hariolf Oberer und Gerhard Seel. Würzburg 1988, 71-90.

BLANCO FERNÁndeZ, Domingo: Un delirio de la virtud? Reflexiones en torno al problema del mal en Kant. In: Kant después de Kant: En el bicentenario de la Crítica de la Razón Práctica. Hrsg. von Javier MUGUERZA und Roberto Rodríguez ARAMAYO. Madrid 1989, 87-116.

BoCarov, V. A.: Analiz kritiki Kantom ontologiceskogo argumenta [Zur Analyse der Kantischen Kritik des ontologischen Arguments]. In: Kantovskij Sbornik (Kaliningrad) 14, 1989, 90-99.

BURKHARDT, Bernd: Hegels Kritik an Kants theoretischer Philosophie, dargestellt und beurteilt an den Themen der metaphysica specialis. München 1989. Rezensionen: J. Splett. In: Theologie und Philosophie (Freiburg i.Br.) 65, 1990, 436 f.; A Schaefer. In: Philosophischer Literaturanzeiger (Frankfurt a. M.) 44, 1991, 130-132; G. Baptist. In: Hegel-Studien (Bonn) 30, 1995, 185-190.

CAIMI, Mario: La metafísica de Kant. La reconstrucción de la argumentación del escrito de Kant «Los progresos de la metafísica desde la época de Leibniz y de Wolff». Buenos Aires 1989.

De Pascale, Carla: La nozione di "Male radicale" e le "Lezioni di etica». In: A partire da Kant. L'eredità della "Critica della ragion pratica». Einleitung: Silvestro Marcucci. Hrsg. von Adriano FABRIS und Luca BACCELLI Milano 1989, 143-146.

Di GIOVANNI, George: Free Choice and Radical Evil: The Irrationalism of Kant's Moral Theory. In: Proceedings of the Sixth Interrnational Kant-Congress. Vol. II.2: Group Sessions. Sections C through J. Hrsg. von Gerhard FunKE und Thomas M. SEEBohM. Washington 1989, 311-325.

Dubarle, Dominique: Philosophie critique et ontologie chez Kant. Présentation par Jean Greisch. In: Revue ds Sciences Philosophiques et Théologiques (Paris) 73, 1989, 3-39 (Summary, 40).

FAGGiotTo, Pietro: Introduzione alla metafisica kantiana dell'analogia. Milano 1989. Rezensionen: G. B. Sala. In: Humanitas (Brescia) N. S. 45, 1990, 371 f.

FALKENSTEIN, Lorne: Kant's First Argument in the Metaphysical Exposition. In: Proceedings of the Sixth International Kant-Congress. Vol. II.1: Group Sessions: Sections A and B. Hrsg. von Gerhard FUNKE und Thomas M. SEEBOHM. Washington 1989, 219-227. 
Fernandez de Maliandi, Graciela: Kant and Popper: Towards a Metaphysics of Experience. In: Proceedings of the Sixth International Kant-Congress. Vol. II.2: Group Sessions. Sections $C$ through J. Hrsg. von Gerhard FUNKE und Thomas M. SEEBOHM. Washington 1989, 493-503.

Frigelio, Carlo: Kant's Metaphysics of the Subject and Modern Society. In: South African Journal of Philosophy (Pretoria 8, 1989, 176-181.

GiBBS Robert: Fear of Forgiveness: Kant and the Paradox of Mercy. In: Philosophy and Theololgy (Marquette) 3, 1989, 323-334.

GoDlove, Terry F.: Religion, Interpretation, and Diversity of Belief: The Framework Model from Kant to Durkheim to Davidson. Cambridge 1989. Rezensionen: S. Palmquist. In: Kant-Studien (Berlin) 86, 1995, 365-369.

GreEN, Ronald M.: The Leap of Faith: Kierkegaard's Debt to Kant. In: Philosophy and Theololgy (Marquette) 3, 1989, 385-411.

HOPPE, Hansgeorg: Vom Nutzen und Nachteil der metaphysischen Kategorien-Deduktion. In: Proceedings of the Sixth International Kant-Congress. Vol. II.1: Group Sessions: Sections A and B. Hrsg. von Gerhard FUNKE und Thomas M. SEebHoM. Washington 1989, 241-249.

HuNTER, Graeme: Kant and the Ontological Argument. In: Proceedings of the Sixth International Kant-Congress. Vol. II.2: Group Sessions. Sections C through J. Hrsg. von Gerhard FUNKE und Thomas M. SEEBHOM. Washington 1989, 3-10.

KIM, Chin-Tai: A Critique of Kant's Defense of Theistic Faith. In: Philosophy Research Archives (Bowling Green) 14, 1988/89, 359-369.

KIM, Kuck-Tae: Der dynamische Begriff der Materie bei Leibniz und Kant, dargestellt im Zusammenhang der Entstehung der klassischen Naturwissenschaft und deren metaphysischer Grundlegung. Konstanz 1989.

LACORTE, Carmelo: Kant. Die Versöhnung von Religion und Philosophie. Vorrede zur deutschen Ausgabe von Italo Cubeddu. Aus dem Italienischen von Stefan Heiner. Hamburg 1989.

Leamons, John Franklin: The Positive Side of Transcendent Metaphysics in Immanuel Kant's Philosophy. Univ. Diss.: Austin 1989 ['The University of Texas].

LENK, Hans: Sociomorphic Arguments for a Moral God. Kant's Second and Third Moral Argument for the Postulate of God's Existence. In: Man and World (Den Haag) 22, $1989,97-111$.

MANCINI, Italo: La via kantiana alla religione. In: A partire da Kant. L'eredità della "Critica della ragion praticam. Einleitung: Silvestro Marcucci. Hrsg. von Adriano FABRIS und Luca BACCELLI. Milano 1989, 105-124.

MARTinez Martinez, José A.: Libertad, alma y dios en Kant: de las ideas a los postulados. In: Quaderns de Filosofia i Ciència (Valencia) 15-16, 1989, 321-330.

Moors, Martin: Die Bestimmungsgestalt von Kants Gottesidee und das Gemeinschaftsprinzip. In: Proceedings of the Sixth International Kant-Congress. Vol. II.1: Group Sessions: Sections A and B. Hrsg. von Gerhard FUNKE und Thomas M. SEEBHOM. Washington 1989, 49-65. 
NUYEN, A. T.: The Kantian Theory of Metaphysics. In: Philosophy and Rhetoric (University Park, PA) 22, 1989, 95-109.

Odero, José Miguel: La comunicabilidad de la fe según Kant. In: Revista Española de Teología (Madrid) 49, 1989, 295-306.

ODERO, José Miguel: La universalidad de la iglesia. Algunas reflexiones inspiradas en el pensamiento de Kant. In: Iglesia universal e iglesias particulares. Actas del IX Simposio Internacional de Teología. Pamplona 1989, 231-238.

PalmQuist, Stephen R.: Immanuel Kant: A Christian Philosopher? In: Faith and Philosophy (Wilmore, KY) 6, 1989, 65-75.

PenetTE, Sonia: Teoría del conocimiento posible o metafísica de la libertad. In: Cuadernos de Ética (Buenos Aires) 7, 1989, 85-93.

RosenfIELD, Denis L.: Du mal. Essai pour introduire en philosophie le concept du mal [Kant, Schelling, Hegel]. Paris 1989.

RossI, Philip: Evil and the Moral Power of God. In: Proceedings of the Sixth International Kant-Congress. Vol. II.2: Group Sessions. Sections C through J. Hrsg. von Gerhard FUNKE und Thomas M. SEEBOHM. Washington 1989, 369-381.

SCHUSSLER, Ingeborg: Der Wahrheitscharakter der Metaphysik in Kants Kritik der Urteilskraft. In: Prima Philosophia (Cuxhaven) 15, 1989, 51-87.

SEIFERT, Josef: Das Antinomienproblem als ein Grundproblem aller Metaphysik: Kritik der "Kritik der reinen Vernunft". In: Prima Philosophia (Cuxhaven) 2, 1989, 143-168.

SEN, Pranab Kumar: Kant's Metaphysical Deduction of the Categories. In: Journal of the Indian Academy of Philosophy (Calcutta) 28, Nr. 2, 1989, 10-17.

SIMON, Josef: Die Krise des Wahrheitsbegriffs als Krise der Metaphysik. Nietzsches Alethiologie auf dem Hintergrund der Kantischen Kritik. In: Nietzsche-Studien (Berlin/ New York) 18, 1989, 242-259.

TOGNINI, Giorgio: Sostanza, spontaneità e soggetto nelle concezioni metafisiche di Kant. In: Studi kantiani (Pisa) 2, 1989, 11-55.

TreLOAR, John L.: The Crooked of Humanity: Kant's Struggle with Radical Evil. In: Philosophy and Theology (Milwaukee, WI) 13, 1989, 335-354.

Wood, Allen W[illiam]: The Immortality of Moral Faith. In: Proceedings of the Sixth International Kant-Congress. Vol. II.2: Group Sessions. Sections C through J. Hrsg. von Gerhard FUNKE und Thomas M. SEEBOHM. Washington 1989, 417-437.

YOVEL, Yirmiahu: The Interests of Reason: From Metaphysics to Moral History. In: Kant's Practical Philosophy Reconsidered. Papers Presented at the Seventh Jerusalem Philosophical Encounter. Hrsg. von Yirmiahu Yovel. Dordrecht 1989, 135-148.

YOVEL, Yirmiahu: Spinoza and Kant: Critique of Religion and Biblical Hermeneutics. In: Yovel, Yirmiahu: Spinoza and Other Heretics. Vol II. Princeton 1989, 3-26. 


\section{0}

BellinazZI, Paolo: Conoscenza, Morale, Diritto. Il futuro della metafisica in Leibniz, Kant, Schopenhauer. Pisa 1990.

Bellini, Ornella: La kantiana "deduzione metafisica delle categorie» nella lettura dell'idealista oxoniense Edward Caird. In: Ideologia, teoresi e realtà [Università degli studi di Perugia, Quaderni dell'Istituto di filosofia 8]. Napoli 1990, 27-66.

DüsING, Klaus: Naturteleologie und Metaphysik bei Kant und Hegel. In: Hegel und die "Kritik der Urteilskraft". Hrsg. von Hans-Friedrich FuLDA und Rolf-Peter HORTSMANN. Stuttgart 1990, 139-157.

FERRARI, Jean: L'homme de Dieu dans la dernière philosophie de Kant. In: Lhomme et l'autre. De Suso à Peter Handke. Nancy 1990, 97-107.

FERRAR, Jean: La critique kantienne de la preuve ontologique, "dite cartésienne», de l'existence de Dieu. In: L'argomento ontologico. Hrsg. von Marco M. OLIVETTI. Padova 1990, 247-254.

GeBLER, Fred: Die Gottesvorstellungen in der frühen Theologie Immanuel Kants. Würzburg 1990. Rezensionen: G. B. Sala. In: Kant-Studien (Berlin) 83, 1992, 236238; J. M. Odero. In: Scripta Theologica 25, 1993, 369.

GraubNER, Hans: Physikotheologie und Kinderphysik. Kants und Hamanns gemeinsamer Plan einer Physik für Kinder in der physikotheologischen Tradition des 18. Jahrhunderts. In: Johann Georg Hamann und die Krise der Aufklärung. Acta des fünften Internationalen Hamann-Kolloquiums Münster i. W. (1988). Hrsg. von Bernhard GAjEK und Albert Meier. Frankfurt a. M. u. a. 1990, 99-145.

HarT, James G.: Divine Truth in Husserl and Kant: Some Issues in Phenomenological Theology. In: Phenomenology of the Truth Proper to Religion. Hrsg. von Daniel GUERRIERE. Albany 1990, 221-246.

HONNEFELDER, Ludger: Scientia transcendens. Die formale Bestimmtheit der Seiendheit und Realität in der Metaphysik des Mittelalters und der Neuzeit (Duns Scotus - Suárez - Wolff - Kant - Peirce). Hamburg 1990. Rezensionen: N. Fischer. In: Kant-Studien (Berlin) 89, 1998, 367-370.

HOPING, Helmut: Freiheit im Widerspruch. Eine Untersuchung zur Erbsündenlehre im Ausgang von Immanuel Kant. Innsbruck/ Wien 1990. Rezensionen: G. Cavallar. In: Kant-Studien (Berlin) 85, 1994, 115-117.

KOPPER, Joachim: Quelques remarques sur la doctrine du mal chez Kant. In: Études Philosophiques (Paris) 1990, Nr. 1, 13-19.

MaCKInNon, Donald: Aspects of Kant's Influence on British Theology. In: Kant and His Influence. Hrsg. von George MacDonald ROSS und Tony MACWALTER. Bristol 1990, 348-366.

MARCUCCI, Silvestro: Sulla metafisica kantiana dell'analogia. In: Srudi kantiani (Pisa) 3, 1990, 143-149.

MARTIN, Werner: Bestimmung und Abgrenzung von Ethik und Religion. Ein Beitrag zur Diskussion über das christliche Proprium in der Ethik unter besonderer Berücksichtigung der Philosophie Kants. Pfaffenweiler 1990. 
MATHIEU, Vittorio: L'argomento ontologico per dimostrare l'esistenza dell'etere nell' 'Opus postumum» di Kant. In: L'argomento ontologico. Hrsg. von Marco M. OlvieTTI. Padova 1990, 271-277. Auch in: Archives de Philosophie (Paris) 58, 1990, 271-277.

MELCHIORRE Virgilio: La teologia morale di Kant. Milano 1990.

MEYER, Regina: Für oder wider Gott? Betrachtungen zum Begriff Gott in der Philosophie Immanuel Kants. In: Kant und die französische [sic!] Revolution. Tagung der Sektion Marxistisch-leninistische Philosophie der Karl-Marx-Universität Leipzig am 25. November 1988. In: Aus dem philosophischen Leben der DDR. Informationsbulletin (Berlin) 17, 1990, 54-59.

MrChalson, Gordon E.: Fallen Freedom. Kant on Radical Evil and Moral Regeneration. Cambridge 1990. Rezensionen: M. Midley. In: The Philosophical Quarterly (St. Andrews) 42, 1992, 114-116; M. Gregor. In: The Review of Metaphysics (Washington) 44, 1991, 414-416.

MiLDENBERGER, Friedrich: Der Glaube als Voraussetzung für ein wahres Denken Gottes. Zu Kant und dem Problem von Theologie und Ökonomie. In: Neue Zeitschrift für systematische Theologie und Religionsphilosophie (Berlin/ New York) 32, 1990, 143165.

MosCheTtI, Andrea Mario: La metafisica kantiana dell'analogia nella prospettiva di una esperienza integrale. In: Giornale di Metafisica (Genova) [N. S.] 12, 1990, 243-280.

NussBaum, Charles: Concepts, Judgments, and Unity in Kant's Metaphysical Deduction of the Relational Categories. In: The Journal of the History of Philosophy (Berkeley, CA) 28, 1990, 89-103.

PeRL, Paul: Down to Earth and Up to Religion: Kantian Idealism in Light of Kierkegaard's Leap of Faith. In: Dialogue (PST) 33, 1990, 1-9.

PIEROBON, Frank: Kant et la fondation architectonique de la métaphysique. Vorwort: Marc Richir. Grenoble 1990.

PUECH, Michel: Kant et la métaphysique en 1762-1764: Les leçons de la Metaphysik Herder. In: Érudes Philosophiques (Paris) 1990, Nr. 2, 187-204.

QuinN, Philipp L.: Saving Faith from Kant's Remarkable Antinomy. In: Faith and Philosophy (Wilmore, KY) 7, 1990, 418-433.

SALA, Giovanni B.: Kant und die Frage nach Gott. Gottesbeweise und Gottesbeweiskritik in den Schriften Kants. Berlin - New York 1990 [KSEH 122]. Rezensionen: H. Schöndorf. In: Theologie und Philosophie (Freiburg i.Br.) 67, 1992, 115-118; M. Paolinelli. In: Rivista di Filosofia Neo-scolastica (Milano) 86, 1994, 780-783.

SALA, Giovanni B.: Dio: Un postulato della Ragion Pratica? La "Critica della Ragion Pratica" di Kant (1788). In: La Civiltà Cattolica (Roma) 141, 1990, 327-342.

SEMPLICI Stefano: Dalla teodicea al male radicale. Kant e la dottrina illuminista dell' 'Giustizia di Dio". Padova 1990. Rezensionen: R. Pozzo. In: Kant-Studien (Berlin) 83, 1992, 238-240.

SEVERINO, Emanuele: Kant: Il non esse dell'essente. In: L'argomento ontologico. Hrsg. von Marco M. OliveTTI Padova 1990, 279-298. 
SIMM, Christoph: Kants Ablehnung jeglicher Erbsündenlehre. Münster 1990.

SIMON, Josef: Die Überdehnung der Metaphysik. Kants Kritik des ontologischen Arguments im System seiner kritischen Philosophie. In: L'argomento ontologico. Hrsg. von Marco M. OlivetTI. Padova 1990, 255-270.

WIEHL, Reiner: Kants Kritik des Panpsychismus in der Metaphysik der Subjektivität. In: Hegel und die «Kritik der Urteilskraft». Hrsg. von Hans-Friedrich FuLDA und RolfPeter HorstmanN. Stuttgart 1990, 205-240.

WIMMER, Reiner: Kants kritische Religionsphilosophie. Berlin 1990 [KSEH 124]. Rezensionen: G. B. Sala. In: Theologie und Philosophie (Freiburg i.Br.) 67, 1992, $112-$ 115; H. Olles. In: Philosophischer Literaturanzeiger (Frankfurt a. M.) 48, 1995, $282-$ 284; G. Cavallar. In: Kant-Studien (Berlin) 85, 1994, 110-114.

WISNEFSKE, Ned: Our Natural Knowledge of God: A Prospect for Natural Theology after Kant and Barth. Berlin - New York - Bern u. a. 1990. Rezensionen: S. Palmquist. In: Kant-Studien (Berlin) 87, 1996, 118-122.

1991

AKK (7) = Akten des Siebenten Internationalen Kant-Kongresses Kurfürstliches Schloß zu Mainz 1990. In Verbindung mit Manfred KLEINSCHNIEDER, Rudolf MALTER, Gisela MÜller, Ralf MÜller, Thomas M. Skebohm hrsg. von Gerhard FunKE. Bd. 1: Begrüßungsansprachen, Festvorträge, Plenarvorträge. Bd. II, 1: Sektionsbeiträge Sektionen A - F; Bd. II, 2: Sektionsheiträge Sektionen G - P. Bonn 1991.

Akнutin, A. V.: Sophia and tbe Devil: Kant in the Face of Russian Religious Metaphysics. In: Soviet Studies in Philosophy (Armonk, NY) 29, 1991, 59-89.

BaldaCCHINo, Lewis: Study in Kant's Metaphysics of Aesthetic Experience, Reason and Feeling. Lewiston/Queenston/Lamperer 1991.

BencinvegA, Ermanno: The Metaphysical Structure of Kant's Moral Philosophy. In: Philosophical Topics (Denver, CO) 19, 1991, 17-29.

CAIMI, Mario: Kants Metaphysik. Zu Kants Entwurf einer metaphysica specialis. In: AKK (7) I, 103-126.

CoRDIOLI, Roberta: La metafisica kantiana nell'interpretazione di P. F. Strawson. In: Verifiche (Trento) 20, 1991, 291-314.

Cramer, Konrad: Metaphysik und Erfahrung in Kants Grundlegung der Ethik. In: Neue Hefte für Philosophie (Göttingen) 30/31, 1991, 15-68.

CRISTAUdo, Wayne: The Metaphysics of Scicence and Freedom. From Descartes to Kant to Hegel. Aldershot/ Brookfield u. ö. 1991.

DÚsING, Klaus: Hegels Metaphysikkritik. Dargestellt am Beispiel seiner Auseinandersetzung mit Kants Antinomienlehre. In: Denken unterwegs. Philosophie im Kräftefeld sozialen und politischen Engagements. Festschrift für Heinz Kimmerle zu seinem 60. Geburtstag. Hrsg. von Henk Costerling und Frans De JONG. Amsterdam 1991, 109125 . 
ÉCOLE, Jean: De la connaissance qu'avait Kant de la métaphysique, ou Kant avait-il lu les ouvrages métaphysiques de Wolff? In: Archiv für Geschichte der Philosophie (Berlin/ New York) 73, 1991, 260-276.

EsPosito, Costantino: Kants philosophische Religionslehre zwischen reiner und praktischer Vernunft. In: AKK (7) II, 2, 237-252.

Fenves, Peter D.: A Peculiar Fate. Metaphysics and World-History in Kant. Ithaca/ London 1991.

FREULER, Léo: L'origine et la fonction de la métaphysica naturalis chez Kant. In: Revue de Métaphysique et de Morale (Paris) 96, 1991, 371-394.

HABICHLER, Alfred: Reich Gottes als Thema des Denkens bei Kant. Entwicklungsgeschichtliche und systematische Studie zur Kantischen Reich-GottesLehre. Mainz 1991. Rezensionen: J. Boada. In: Actualidad Bibliográfica 57, 1992, 132133.

Heidegger, Martin: Kant und das Problem der Metaphysik. Fünfte, vermehrte Auflage. Hrsg. von Friedrich-Wilhelm VoN HerRman. Frankfurt 1991.

Kant on Metaphysics. [Religion and Philosophy on Video.] New York: Insight Media $1991.60 \mathrm{~min}$.

Kant's Philosophy of Religion Reconsidered. Hrsg. von Philip J. Rossi und Michael Wreen. Bloomington, IN, 1991. Rezensionen: J. M. Odero. In: Scriptura Theologica 26, 1994, 321-322. - Darin: ANDERSON-Gold, Sharon: God and Community: An Inquiry into Religious Implications of the Highest Good, 113-131; MulHolland, Leslie A.: Freedom and Providence in Kant's Account of Religion: The Problem of Expiation, 77102; Perovich, Anthuny N.: "For Reason... also Has Its Mysteries": Immortality, Religion, and "The End of All Things", 165-180; Runzo, Joseph: Kant on Reason and Justified Belief in God, 22-39; SAVAGE, Denis: Kant's Rejection of Divine Revelation and His Theory of Radical Evil, 54-76; WOLTERSTORFF, Nicholas: Conundrums in Kant's Rational Religion, 40-53.

KURSCH, Regina: Kant oder Leibniz - Linearität oder Selbstorganisation? Ein metaphysischer Beitrag zur «Aufklärung» der Naturwissenschaften. In: Philosophischer Taschenkalender. Jahrbuch zum Streit der Fakultäten. Hrsg im Auftrag der Gesellschaft fur Philosophische Bildung von Rüdiger SCHMIDT und Bettina WAHRIG-SCHMIDT. Lübeck 1991, 188-207.

Langthaler, Rudolf: Kants Ethik als "System der Zwecke». Perspektiven einer modifizierten Idee der "moralischen Teleologie" und Ethikotheologie. Berlin/ New York 1991 [KSEH Nr 125]. Rezensionen: G. B. Sala. In: Theologie und Philosophie (Freiburg i. Br.) 67, 1992, 435-437.

LOHMAR, Dierer: Zum Aufbau des Beweises von Lehrsatz 1 in Kants Kritik der praktischen Vernunft. Die Bedeutung des voluntaristischen Gottesbegriffs für Kants Kategorischen Imperativ. In: AKK (7) II, 1, 343-352.

LOREnZEN, Max-Otto: Metaphysik als Grenzgang. Die Idee der Aufklärung unter dem Primat der praktischen Vernunft in der Philosophie Immanuel Kants. Hamburg 1991. Rezensionen: E. Colomer. In: Actualidad Bibliográfica de Filosofía y Teología (Barcelona) 59, 1993, 130. 
MALTER, Rudolf: Zukunftswissen aus dem Jenseits? Swedenborg, Kant und Schopenhauer über das "Geistersehen". In: Zur Erschließung von Zukunft in den Religionen. Zukunftserwartung und Gegenwartsbewältigung in der Religionsgeschichte. Hrsg. von Hans WIBMANN. Würzburg 1991, 185-196.

MOORS, Martin: Reale Zweckmäßigkeit der Natur und Transzendentaltheologie. In: AKK (7) II, 2, 253-265.

MOSCATTI, Antonella: Teoria dell'esperienza e problema della metafisica. Interpretazioni Kantiane a confronto. In: Il Cannocchiale (Roma) 1991, Nr. 1-2, 213-229.

PALMQUiST, Stephen R.: Kant's Theistic Solution to the Problem of Transcendental Theology. In: Kant and the Transcendental Problem. International Symposium. Ed. Rodica Croitoru. Bukarest 1991, 148-178.

ROD, Wolfgang: Kants reine Naturwissenschaft als kritische Metaphysik. In: dialectica (Biel/Bienne) 45, 1991, 117-131.

Rosas, Alejandro: Transzendentaler Idealismus und Widerlegung der Skepsis bei Kant. Untersuchung zur analytischen und metaphysischen Schicht in der "Kritik der reinen Vernunft". Würzburg 1991.

Rossi, Philip J.: Moral Struggle and Moral Conversion in Kant's Religion. In: AKK (7) II, 2, 283-293.

SAlA, S. J., Giovanni B.: Der moralische Gotresbeweis: Entwicklung und Spannungen in der kantischen Fassung. In: AKK (7) II, 2, 295-304.

SCHOENBORG, Alexander von: Kant's Philosophy of Religion Reconsidered: Reason, Religion, and the Unfinished Business of the Enlightenment. In: Philosophy and Theology (Milwaukee, WI) 6, 1991,101-116.

STAHL, Joachim: Kritische Philosophie und Theorie der Gesellschaft. Zum Begriff negativer Metaphysik bei Kant und Adorno. Frankfurt/Bern/New York 1991.

WENDEL, Hans Jürgen: Apriorische Einsicht und metaphysische Notwendigkeit. Eine Auseinandersetzung mit Kripkes Kant-Kritik. In: Kant-Studien (Berlin) 82, 1991, 6380.

WestPhal, Kenneth R.: Kant's Qualified Principle of Obedience to Authority in the Metaphysical Elements of Justice. In: AKK (7) II, 2, 353-366.

YAMASHITA, Yoshiaki: Über die Fortschritte der Metaphysik. Betrachtungen zu einer nachgelassenen Schrift Kants. In: Philosophisches Jahrbuch der Görres-Gesellschaft (München) 98, 1991, 267-289.

\section{2}

AMERIKS, Karl: The Critique of Metaphysics: Kant and Traditional Ontology. In: The Cambridge Companion to Kant. Ed. Paul GUYER. Cambridge 1992, 249-279.

Barale, Massimo: Critica del giudizio e metafisica del senso. In: Archivio di Storia della Cultura (Napoli) 5, 1992, 65-86.

BERHOF, Hendrikus: 200 anni di teologia e filosofia. Da Kant a Rahner. Ital. Ausgabe besorgt von Michele Fiorillo. Torino 1992.* 
Desturt DE TRACY, Antoine Louis Claude: De la métaphysique de Kant. In: Ders.: Mémoire sur la faculté de penser.- De la métaphysique de Kant et autres textes. Paris 1992, 243-293.

FLAMARIQUE, Lourdes: La dialéctica transcendental o la sinrazón de la metafísica. In: Topicos $2,1992,37-60$.

Freuler, Léo: Kant et la métaphysique spéculative. Paris 1992. Rezensionen: A. Denker. In: Kant-Studien (Berlin) 88, 1997, 123-126.

Freuler, Léo: Les antinomies cosmologiques de Kant. In: Revue de Théologie et de Philosophie (Lausanne) 124, 1992, 19-39.

Friedman R. Z.: Maimonides and Kant on Metaphysics and Piety. In: The Review of Metaphysics (Washington) 45, 1992, 773-801.

Galbraith, Elizabeth: Kant and Religious Doctrines. In: Enlightenment and Dissent (Aberystwyth, Wales) 1992, n. 11, 23-45.

GEISLER, Ralf: Kants moralischer Gottesbeweis im protestantischen Positivismus. Göttingen 1992.

GIRALT, Paul: Unidad del conocimiento y fundamentación de la metafísica en la «Crítica de la razón pura». In: Acta Philosophica (Roma) 1, 1992, 293-315.

Kant über Religion. Hrsg. von Friedo RICKEN und François MARTY. Stuttgart 1992. Rezensionen: N. Fischer. In: Theologie und Glaube (Paderborn) 83, 1993, 220-223; J. Splett. In: Theologie und Philosophie (Freiburg i.Br.) 69, 1994, 107 f. - Darin: BAUMGARTNER, Hans-Michael: Das "ethische gemeine Wesen" und die Kirche in Kants "Religionsschrift», 156-167; FORSHNER, Maximilian: Das Ideal des moralischen Glaubens. Religionsphilosophie in Kants Reflexionen, 83-99; MARTY, François: Die Frage der Religion als Probierstein eines kritischen Denkens, 52-66; RICKEN, Friedo: Kanon und Organon. Religion und Offenbarung im «Streit der Fakultäten», 181-194; SALA, Giovanni B.: Die Lehre von Jesus Christus in Kants Religionsschrift, 143-155; VOSSENKUHL, Wilhelm: Die Paradoxie in Kants Religionsschrift und die Ansprüche des moralischen Glaubens, 168-180; WIMMER, Reiner: Die Religionsphilosophie im «Opus postumum", 195-229; WINTER, Alois: Theologiegeschichtliche und literarische Hintergründe der Religionsphilosophie Kants, 17-51.

KITTSTEINER, Heinz Dieter: Religion, Aufklärung und Geschichte in Kants «Religion innerhalb der Grenzen der bloßen Vernunftw. In: Die Vernunft und ihr Gott. Studien zum Streit zwischen Religion und Aufklärung. Hrsg. von Enno RUDOLPH. Stuttgart 1992, 33-52.

MALTER, Rudolf: Franz Brentanos Kritik der Kantischen Gotteslehre im Rückgang auf Leibniz. In: Grundlagen einer transzendentalphilosophischen Systematik. Hrsg. von Gerhard FUNKE. Stuttgart 1992, 81-91.

Mancini, S.: La metafisica segreta di Kant. Su un recente saggio di Virgilio Melchiorre. In: Rivista di Filosofia Neo-scolastica (Milano) 84, 1992, 168-177.

Marion, Jean-Luc: Is the Ontological Argument Ontological? The Argument According to Anselm and Its Metaphysical Interpretation According to Kant. In: The Journal of the History of Philosophy (Berkeley, CA) 30, 1992, 201-218. 
NISTOR, Mihai: Immanuel Kant on Theöretical Arguments Regarding the Existence of God. In: Critic and Doctrinal in Kant. Hrsg. von Rodica CROITORU. The Third International Symposion, September 19-21, 1992. Bukarest o.J.[1992], 115-118.

OJZERMAN, T[eodor] I.: Filosofija Kanta kak radikal'naja revisija metafiziki i ee novoe obosnovanie [Kants Philosophie als radikale Revision der Metaphysik und ihre neuen Grundlagen]. In: Voprosy Filosofii (Moskau) 1992, Nr. 11, 115-128.

PALMQUIST, Stephen: Does Kant Reduce Religion to Morality? In: Kant-Studien (Berlin) 83, 1992, 129-148.

PanaIte, Corneliu: La théologie négative de la pensée dans la métaphysique de Kant et de Hegel. In: Critic and Doctrinal in Kant. Edited by Rodica Croitoru. The Third International Symposion, September 19-21, 1992. Bukarest o.J.[1992], 119-122.

SIU, Paul Y.: Kant's Moral Christology in Religion within the Limits of Reason Alone. In: The Asia Journal of Theology (Singapore) 6, 1992, 169-182.

VeCERKA, K.: Did Kant Invalidate the Proofs of God's Existence [tschechisch]. In: Filozofska Istrazivanja (Zagreb) 47(11), 1992, 641-649.

WINTER, Alois: Die Kritik der Urteilskraft vor dem Hintergrund der Kantischen Religionsphilosophie: Perspektiven und Erträge. In: Giudizio e interpretazione in Kant a cura di Giuseppe Riconda, Giovanni FerretI, Andrea Poma. Genova 1992, 185227. [Atti del Convegno Internazionale per il centenario della Critica del Giudizio di Immanuel Kant, Macerata, 3-5 Octobre 1990.]

WoOD, Allan W.: Rational Theology, Moral Faith, and Religion. In: The Cambridge Companion to Kant. Ed. Paul GuYrr. Cambridge 1992, 394-416.

1993

BAUM, Manfred: Metaphysik und Kritik in Kants theoretischer Philosophie. In: Kategorien der Existenz. Festschrift für Wolfgang Janke. Hrsg. von Klaus HELD und Jochen HENNIGFELD. Würzburg 1993, 13-30.

BuTTs, Robert E.: The Methodological Structure of Kant's Metaphysics of Science [1986]. In: Ders.: Historical Pragmatics. Philosophical Essays. Hrsg. von Robert S. CoHEN. Boston 1993, 79-113.

Caimi, Mario: Motivas metafísicos en la Crítica del Juicio teleológico. In: Homenaje a Kant. Hrsg. von José SAZBON. Con textos de Hanna Arendt e.a.. Buenos Aires 1993, 9-26.

DAVIDOVICH, Adina: Religion as a Province of Meaning. The Kantian Foundations of Modern Theology. Minneapolis, MN, 1993.

FaGGIOTTO, Pietro: Chiarimenti sulla metafisica Kantiana della analogia. In: Aquinas (Roma) 36, 1993, 163-168.

FISCHER, Norbert: Zur neueren Diskussion um Kants Religionsphilosophie. In: Theologie und Glaube (Paderborn) 83, 1993, 170-194.

FlamARIQUE, Lourdes: Dos momentos de la metafísica en el criticismo kantiano. Navarra 1993. 
Göbel, Wolfgang: Der Wille zu Gott und das Handeln in der Welt: M. Luther - Johannes v. Kreuz - I. Kant. Freiburg (CH), Freiburg i. Br. 1993.

KORSCH, Dietrich: Das doppelte Absolute. Reflexion und Religion im Medium des Geistes [Kant - Schelling - Schleiermacher]. In: Neue Zeitschrift für systematische Theologie (Berlin) 35, 1993, 28-56.

LAYWINE, Alison: Kant's Early Metaphysics and the Origins of Critical Philosophy. Atascadero 1993. R: R. Pozzo. In: The Review of Metaphysics (Washington) 54, 2000, 157-158.

LINDLER, Konrad: Auf der Suche nach einer «Metaphysik der Natur»». Einige Bemerkungen zur Leipziger Kantrezeption (1789/90). In: Naturzweckmäßigkeit und ästhetische Kultur. Studien zu Kants Kritik der Urteilskraft. Hrsg. von Karl-Heinz SCHwaDE und Martina Tном. St. Augustin 1993, 151-165.

Lowe, Walter: Theology and Difference: The Wound of Reason. Bloomington, IN 1993.

RIVERA DE ROSALES, Jacinto: El punto de partida de la metafísica transcendental. Un estudio crítico de la obra kantiana. Madrid 1993, Rezensionen: V. Serrano. In: Anales del Seminario de Historia de Filosofía (Madrid) 11, 1994, 253ff.; M. Caimi. In: KantStudien (Berlin) 89, 1998, 100-104.

SALA, Giovanni B.: Wohlverhalten und Wohlergehen. Der moralische Gottesbeweis in den Schriften Kants. In: Theologie und Philosophie (Freiburg i.Br.) 68, 1993, 182-207.

SEIDEL, Bodo: Kant und die Zielgerade der Historiotheologie in der Späten Aufklärung. Ein Beytrag zum Anheben der Kantischen Philosophie unter den Betreybern der theologischen Wissenschaft in Jena. In: "Das Kantische Evangelium». Der Frühkantianismus an der Universität Jena von 1785-1800 und seine Vorgeschichte. Ein Begleitkatalog. Hrsg. von Norbert HiNSKE, Erhard LANGE und Horst SCHROPfER. Stuttgart 1993, 139-169.

SEIFERT, Josef: El problema de las antinomias considerado como un problema fondamental de toda Metafísica: Crítica de la Crítica de la razón pura. In: Revista de Filosofía (Madrid) 6, 1993, 89-117.

Stefanov, Ivan S.: Heinz Heimsoeth und Immanuel Kant. Das Problem der Möglichkeit einer "praktisch-dogmatischen" Metaphysik [bulgarisch]. In: Filosoficki Pregled (Sofija) 3, 1993, 35-60.

STroble, Paul E.: "Without Running Riot»: Kant, Analogical Language, and Theological Discourse. In: Sophia (Victoria, Austr.) 32, 1993, 57-72.

THEIS, Robert: Kants Transformation der Ontotheologie. Über die Möglichkeit einer philosophischen Theologie im Schatten des Kritizismus. In: Der eine Gott und die vielen Kulturen. Inkulturation und christliche Gottesvorstellung. Hrsg. von Konrad HILPERT und Karl Heinz OHLIG. Zürich 1993, 127-140.

VALENT, Italo: Il problema del "Dasein" nella critica kantiana dell'ontoteologia. In: L. Perissinoto e.a.: Dio e la ragione. Anselmo d'Aosta, l'argomento ontologico e la filosofia. Genova 1993, 135-169.

VIEILLARD-BARON, Jean-Louis: L'expérience métaphysique et le transcendantal. In: KantStudien (Berlin) 84, 1993, 25-37. 
WHITE, David A.: Kant on Plato and the Metaphysics of Purpose. In: History of Philosophy Quarterly (Bowling Green, OH) 10, 1993, 67-82.

WILliams, Harvey: Is the Watershed Leaking? A Fresh Reappraisal of Immanuel Kant's Attitude to Metaphysics. In: Proceedings of the Heraclitean Society (Kalamazoo, MI) 16, 1991-1993, 49-60.

\section{4}

Anderson, Abraham: Metaphysics and Methods in Descartes and Kant. In: The Philosophical Quarterly (St. Andrews) 44, 1994, 101-109.

AxINN, Sidney: The Logic of Hope: Extensions of Kant's View of Religion. Amsterdam/ Atlanta 1994. Rezensionen: G. Cavallar. In: Kant-Studien (Berlin) 89, 1998, 230-232.

BELlU, Niculae: Les confrontations théologiques dans l'analyse kantienne du phénomène religieux. In: Revue Roumaine de Philosophie (Bucareste) 38, 1994, 21-28.

Brinkmann, Klaus: Hegel's Critique of Kant and Pre-Kantian Metaphysics. In: Hegel Reconsidered. Hrsg. von H. Tristram Engel.hard Jr. und Terry PINKARD. Dordrecht u.a. 1994, 57-78.

BuCHDAHL, Gerd: Science and God: The Topology of the Kantian World. In: Kant and Contemporary Epistemology. Hrsg. von Paolo PARrini. Dordrecht u.a. 1994, 1-25.

CONSTANDACHE, G. G.: Moralité et sentiment religieux chez Kant. In: Revue Roumaine de Philosophie (Bucareste) 38, 1994, 43-47.

Davidovich, Adina: How to Read Religion within the Limits of Reason Alone. In: KantStudien (Berlin) 85, 1994, 1-14.

Dell'oro, Regina O. M.: From Existence to the Ideal: Continuity and Development in Kant's Theology. New York 1994. Rezensionen: S. Palmquist. In: Kant-Studien (Berlin) 89, 1998, 109-113.

DzIDA, Andrew J.: Thinking Critically about Religion: An Investigation of the Defense of the Rationality of Religious Commitment in some of the Writings of Emmanuel Kant and of James Muyskens. Univ. Diss. Notre Dame 1994.

EFFERTZ, Dirk: Kants Metaphysik: Welt und Freiheit. Zur Transformation des Systems der Ideen in der Kritik der Urteilskraft. Freiburg 1994. Rezensionen: D. Thiel. In: Philosophischer Literaturanzeiger (Frankfurt a. M.) 49, 1996, 331-336.

FAGGIOTTO, Pietro: Intorno alla metafisica kantiana della analogia. In: Humanitas (Brescia) $49,1994,430-432$.

FISCHER, Norbert: Freiheit und Endlichkeit. $\mathrm{Zu}$ ihrem Spannungsverhältnis in der Philosophie Platons und Kant. In: Theologie und Glaube (Paderborn) 84, 1994, 401414.

GRONEWALD, Bernward: Das metaphysische Problem der Freiheit. Versuch einer Revision im Ausgang von der Kantischen Lösung. In: Philosophisches Jahrbuch der Görresgesellschaft (München) 101, 1994/2, 347-357. 
HOLZ, Harald: Philosophische und theologische Antinomik bei Kant und Thomas von Aquin. In: Ders.: Geist in Geschichte. Idealismus-Studien. I. Halbband: Immanuel Kant. Die systematische Kernidee der Geschichte. Würzburg 1994, 11-27.

HONNEFELDER, Ludger: Vernunft und Metaphysik. Die dreistufige Konstitution ihres Gegenstandes bei Duns Scotus und Kant. In: Grenzbestimmungen der Vernunft. Hrsg. von Petra Kolmer und Harald Korten. Freiburg/ München 1994, 319-350.

IDALOVICHI, Israel: A Critical Metaphysical Exposition of Kant and Frege's Concepts of Space. In: South African Journal of Philosophy (Pretoria 13, 1994, 79-87.

ILIESCU, Victor: Die Religion im Rahmen der Vernunft. Andeutungen zu einem neuen Standpunkt. In: Revue Roumaine de Philosophie (Bucareste) 38, 1994, 17-20.

KALINNIKOV, Leonard A.: V. Solovjev und I. Kant: ethische Konvergenzen und Divergenzen: Menschvergottung oder die vergöttlichte Menschheit [russisch]. In: Kantovskij Sbornik (Kaliningrad) 18, 1994, 45-58.

Kant: de la Crítica a la Filosofia de la Religión. Hrsg. von Dulce María Granja CaSTRO. Barcelona/México 1994. - Darin: AlLISON, Henry E.: Apercepción y analiticidad en la deducción B, 45-67; CAFFARENA, José Gómez: Kant y la filosofía de la religión, 185-211; GarZón, Ernesto: La paz republicana, 161-183; Granja CASTro, Dulce María: ¿Es solipsista el 'yo' kantiano?, 69-93; HeNRICH, Dieter: La estructura de la prueba en la deducción trascendental de Kant, 23-44; MUGUERZA, Javier: Kant y el sueño de la razón, 125-159; PEREDA, Carlos: La tercera antinomia y las perplejidades de la libertad, 95-123.

KOPPER, Joachim: La philosophie de L'Action (Blondel, 1893) et la foi religieuse pur (Kant, 1793). In: Recherches blondéliennes. Sous la direction de Jean FERRARI. Dijon 1994, 69-76.

LONGUENESSE, Béatrice: Logique et métaphysique dans le système critique. L'example de la causalité. In: Bulletin de la Société Française de Philosophie (Paris) 88, 1994, 65-105.

MARCUCCI Silvestro: Alcune osservazioni storico-critiche sul rapporto morale-felicitàreligione in Kant. In: Studi kantiani (Pisa) 7, 103-110.

Marston, Robert: Autonomy and the Agent's Final End: Hegel's Reformulation of Kant's Argument for the Rationality of Religion. Univ. Diss. Cornell 1994.

Morrison, II, Roy D.: Science, Theology, and the Transcendental Horizon. Einstein, Kant, and Tillich. Atlanta 1994.

NARSKIJ, I. S.: Die Entwicklung der ethischen Ideen in der "»Religion innerhalb der Grenzen der bloßen Vernunft” [russisch]. In: Kantovskij Sbornik (Kaliningrad) 18, 1994, 20-28.

Nicolosi, Salvatore: Metafisica ed esistenza di Dio nel periodo precritico di Kant. In: Aquinas (Roma) 37, 1994, 501-521.

NuYEM, A. Tuan: Kant on God, Immortality, and the Highest Good. In: The Southern Journal of Philosophy (Memphis) 32, 1994, 121-134.

PALMQUisT, Stephen: "The Kingdom of God is at Hand!» (Did Kant Really Say That?). In: History of Philosophy Quarterly (Bowling Green, OH) 11, 1994, 421-437. 
Pellegrino, Pietro: Kant tra metafisica e scientismo della ragione pura. In: La Fardelliana $12,1994,139-155$.

Religião, História e Razão da Aufklärung ao Romantismo. Colóquio Comemorativo dos 200 anos da publicação de A religião nos limites da simples Razão de Immanuel Kant. Coordenação de Manuel J. Carmo Ferreira e Leonel Riberio do Santos. Lisboa 1994. - Darin: BarATA-MOURA, José: O tratado teológico-político de Kant. No segundo centenário de Die Religion innerhalb der Grenzen der bloßen Vernunft, 65-96, BARDOSA DA COSTA FREITAS, Manuel: Elementos para uma cristologia kantiana, 25-33; BECKERT, Cristina: Mal radical e má fé, 35-48; CADETE, Teresa R.: Religão, âncora do bem-estar? O desafio kantiano em Friedrich Schiller, 229-240; CERQUEIRA GONÇALVES, Joaquim: Experiência, existência de deus e religião em "A Religião nos limites da simples razão" de Kant, 11-23; CORREIA, Carlos João: O mal radical e a visão mítica do mundo, 49-63; MESQUITA, António Pedro: O conflito das racionalidades: A propósito da crítica Kantiana do argumento ontológico, 125-146; PIMENTEL, Manuel Cândido: Amorim Viana e Kant: A Fé nos limites de razão, 279-287; SOROMENHO MARQUES, Viriato: Notas para uma leitura política da Religion, 97-104; VIEGAS, Pedro: Da Teleologia à Teologia ética: em busca do sentido radical da pregunta, "o que é o homem?", 173-184; XAVIER, Maria Leonor L. O.: O argumento ontológico: Kant e Santo Anselmo, 107-123.

Religion et Philosophie. La religion dans les limites de la pure raison d'Immanuel Kant à son 200 e anniversaire. Hrsg., mit Vorwort und Einleitung von Rodica CROITORU. Bucareste 1994. [Revue Roumaine de Philosophie 38, Nr. 1-2, 1994.]

Riberiro dos SANTOS, Leonel: Crítica e metafísica: a interpretação kantiana de Leibniz. In: Ders.: A razão sensível. Estudos Kantianos. Lisboa 1994, 99-116.

RiberiRo DOS SANTOS, Leonel: Sobre a ideia e o progresso da metafísica. In: Ders.: A razão sensível. Estudos Kantianos. Lisboa 1994, 171-176.

Rigobello, Armando: Oltre il trascendentale. Roma 1994; Rezensionen: G. L. Linguitti. In: Studi kantiani (Pisa) 8, 1995, 203-204.

RoDríguez Gonzales, Mariano: Metafísica de la finalidad natural. Su metamorfosis en la linea Kant - Schopenhauer - Nierzsche. In: Pensamiento (Madrid) 50, 1994, 435-455.

SCHUlze, St. - Binder, J.: Kants Verteidigung der Metaphysik. Marburg 1994; Rezensionen: V. Mudroch. In: Kant-Studien (Berlin) 87, 1996, 471-475; L. de Vos. In: Tijdschrift voor Filosofie (Leuven) 58, 1996, 759-760.

Smeljov, V.: I. Kant und L. Tolstoi über die Wahrheiten der Religion [russisch]. In: Kantovskij Sbornik (Kaliningrad) 18, 1994, 58-73.

THEIS, Robert: Gott. Untersuchung zur Entwicklung des theologischen Diskurses in Kants Schriften zur theoretischen Philosophie bis hin zum Erscheinen der Kritik der reinen Vernunft. Stuttgart 1994. Rezensionen: J. Boada. In: Actualidad Bibliográfica de Filosofía y Teología (Barcelona) 62, 1994, 298-300; M. Moxter. In: FAZ 26.4.1995; L. Fonnesu. In: Studi kantiani (Pisa) 9, 1996, 151-152; M. de Gandillac. In: Revue de Métaphysique et de Morale (Paris) 1997, 455-456.

THEIS, Robers: Neuer Wein in alten Schäuchen. Kants Behandlung der rationalen Theologie in seinen Vorlesungen über Metaphysik aus den 60er und 70er Jahren. In: Königsberg. Beiträge zu einem besonderen Kapitel der deutschen Geistesgeschichte des 18. Jahrhunderts. Hrsg. von J. KOHNEN. Frankfurt a. M. u.a. 1994, 127-159. 
VITIELLO, Vincenzo: Gott denken. Der ontologische Gottesbeweis bei Leibniz und Kant. In: Leibniz und die Frage nach der Subjektivität. Hrsg. von R. CRISTIN. 1994, 133-158.

WAGNER, Falk: Absolute Notwendigkeit. Ein Beitrag zur Art der Aufhebung der kritizistischen Bestreitung des kosmo-ontotheologischen Arguments. In: Aufhebung der Transzendentalphilosophie. Hrsg. von Thomas Sören HofFMAN und Franz UNGLER. Würzburg 1994, 143-167.

WoOD, Allen: Die Rolle der Religion in der Kantischen Philosophie. Aus dem Engl. ins Russische übersetzt von Leonid A. Kalinnikov. In: Kantovskij Sbornik (Kaliningrad) 18, 1994, 3-11.

1995

L'année 1793. Kant. Sur la politique et la religion. Sous la direction de Jean FERRARI. Actes du ler Congrès de la Société d'Études Kantiennes de Langue Française (Dijon, 13-15 mai 1993). Paris 1995. - Darin: CRAMPE-CASNABET, Michèle: La religion comme représentation, 161-163; DE TERNAY, Henri: Réflexion sur l'analogie entre l'Église et l'Etat dans La Religion dans les limites de la simple raison, 173-178; GRONDIN, Jean: Lactualité de La religion dans les limites de la simple raison, 211-215; HAMOU, Philippe: Leibniz et les Progrès de la métaphysique, 219-224; JOOS, Jean-Ernest Ph. D.: Kant en 1793. De la désincarnation du christ à la destitution du roi, 169-172; KOPPER, Joachim: La "Jerusalem" de Mendelssohn et la "religion" de Kant, 43-50; MALTER, Rudolf: Le concept de l'Église chez Kant, 165-168; MAvouangui, David: Animalité et humanité. A propos du mal radical chez Kant, 191-194; MERLE, Jean-Christophe: La volonté dans la seconde version de l'Essai d'une critique de toute révélation (1793) et l'émergence de la dimension pratique de la religion chez Fichte, 225-232; ORTIGUES, Edmond: La foi kantienne dans l'histoire de la religion et du droit, 205-209; PAUL, Jean-Marie: La laïcisation de l'héritage luthérien dans La religion dans les limites de la simple raison, 178183; SCHUSSLER, Ingeborg: Le mal chez Kant et Schelling, 199-203; VUILLEMIN, Jules: Raison finie et sentiment religieux, 51-60; WICHMANN, Heinz: Éthique et religion. Paul Menzer et son interprétation de la philosophie kantienne de la religion, 153-160.

BACIU, Mihai: Kant et la tolérance religieuse. In: The Critical Philosophy and the Function of Cognition. Proceedings of the Fifth International Symposion of the Romanian Kant Society 19-21 September 1995. Hrsg. von Rodica CROITORU. Bucuresti 1995, $217-$ 229.

Bickmann, Claudia: Auf dem Wege zu einer Metaphysik der Freiheit: Kants Idee der Vollendung der Kopernikanischen Wende im Experiment der Vernunft mit sich selbst. In: Kant-Studien (Berlin) 86, 1995, 321-330.

BRANDT, Reinhard: Ein problematischer Absatz im «Ersten Stück» von Kants «Religion innerhalb der Grenzen der bloßen Vernunft». In: Trascendenza, Trascendentale, Esperienza. Studi in onore di Vittorio Mathieu [Anuario Filosofico 63, 1995, 1-3], 337349.

CARTER, Stephen L.: Religious Resistance to the Kantian Sovereign. In: Nomos (New York) 37, 1995, 288-308.

DAVIS, Gordon F.: The Self and Spatial Representation in Kant's Metaphysics of Experience: From the First Critique to the Opus Postumum. In: Eidos (Waterloo, Ont.) 12, 1995 , n. 2, 27-48. 
DELL'ORO, Regina O. M.: From Existence to the Ideal: Continuity and Development in Kant's Theology. New York 1995.

DENKER, Alfred: Kant und Fichte: Kann die Religion vernünftig sein? In: Religionsphilosophie 1995, 41-58. [Fichte-Studien 8]

Esposito, Costantino: Il posto cruciale della filosofia della religione nel pensiero di Kant. In: Rivista di Storia della Filosofia (Milano) 50, 1995, 277-311.

FAGGIOTTO, Pietro: Kant e le metafisiche scolastiche. In: Fenomenologia e Società (Milano) $18,1995,4-16$.

FERRETTl, Giovanni: Ontologia e teologia in Kant. Con commentari di testi kantiani. Macerata 1995; Rezensionen: M. Barale. In: Studi kantiani (Pisa) 9, 1996, 153-158.

Ferro, Mário - TAVAres, Manuel: Análise da obra Fundamentos da Metafísica dos Costumes de Kant. Lisboa 1995.

GARELLI, G.: L'oceano della metafisica. Una metafora di Kant. In: aut aut 265/266, 1995, 103-132.

Proceedings of the Eighth International Kant Congress, Memphis, 1-5 March 1995; vol. I. 1, 2, 3; vol. II. 1, 2. Edited by Hoke RoBINSON. Milwaukee 1995 [= PKC (8)].

GaSS Michael: Kant on Moral Alienation in Religion. In: PKC (8), Il.2, 1995, 651-659.

GrIER, Michelle G.: Kant's Rejection of Rational Theology. In: PKC (8), II.2, 1995, 641650.

JIMÉNEZ, José D.: Kant: La religión como «veneración moral pura de Dios». In: Pensamiento (Madrid) 51, 1995, 69-88.

JoHSON, Darrell: Kant's Metaphysical Deduction. In: PKC (8), II.1, 1995, 269-275.

JONG, Willem R. de: How is Metaphysics as a Science Possible? Kant on the Distinction between Philosophical and Mathematical Method. In: The Review of Metaphysics (Washington) 49, 1995, 235-274.

KANAWROM, Valentin: Ekskurs kum «Religijata v granicite na samija razum» [Exkurs über "Die Religion innerhalb der Grenzen der bloßen Vernunft"]. In: Filosofski Alternativi (Sofija) 3, 1995, 10-12.

KoCH, József: Kritik an der autoritären und Glaube an die humanistische Religion: I. Kants Religionsauffassung. In: Religion und Erziehung in Aufklärungsphilosophie und Aufklärungszeit. Hrsg. von Fritz-Peter HAGER und Dieter JEDAN. Bochum 1995, 6370.

KOPPER, Joachim: Der religiöse Sinn von Handlung. Philosophie der Handlung (Blondel) - Reiner Religionsglaube (Kant). In: Das Tun, der Glaube, die Vernunft. Studien zur Philosophie Maurice Blondels “L'Action" 1893-1993. Hrsg. von A. RAfFel., P. REIFENBERG und G. FUCHS. Würzburg 1995, 116-128.

MALZORN, Wolfgang: Die Seele als Pseudogegenstand metaphysischer Erkenntnis. In: PKC (8), II.1, $1995,349-356$.

MeErson, Michael A.: Put' against Logos. The Critique of Kant and Neo-Kantianism by Russian Religious Philosophers in the Beginning of the Twentieth Century. In: Studies in East European Thought (Norwell, MA) 47, 1995, Nr. 3/4, 225-243. 
METZ, Wilhelm: La religione come compimento dell'eticità nel primo Ficht, a differenza che in Kant. In: Filosofia trascendentale e destinazione etica. Indagini su Fichte. Atti del Convegno di Napoli 10-12 novembre 1992. Hrsg. von Aldo Masullo und Marco IVALDO. Milano 1995, 167-180.

MeYer, Michel: Science et métaphysique chez Kant. Paris 1995 [11988].

NiCOLOSI, Salvatore: Il problema di Dio tra metafisica e morale nel periodo critico di Kant. In: Sapienza (Napoli) 48, 1995, 157-198.

Odero, José-Miguel: Methodological Considerations for the Study of the Kantian Philosophy of Religion. In: PKC (8), II.2, 1995, 633-639.

PRIES, Christine: Übergänge ohne Brücken. Kants Erhabenes zwischen Kritik und Metaphysik. Berlin 1995. Rezensionen: G. Böhme. In: Zeitschrift für philosophische Forschung (Frankfurt a. M.) 52, 1998, 487-489.

QUITTERER, Josef: Metaphysik als Wissenschaft in der kritischen Philosophie Kants. In: Salzburger Jahrbuch für Philosophie 45, 1995, 97-108.

Romero Baró, José María: La Física de Newton en la Metafísica de Kant. In: Aquinas (Roma) 38, 1995, 553-573.

SCHÖNDORF, Harald: Setzt Kants Philosophie die Existenz Gottes voraus? In: Kant-Studien (Berlin) 86, 1995, 175-195.

SCHÖNFELD, Martin: Kant's Early Philosophy of Nature: Science and Metaphysics. Univ. Diss. Indiana 1995.

VOLKAMNN-SCHLUCK, Karl-Heinz: Kants transzendentale Metaphysik und die Begründung der Naturwissenschaften. Würzburg 1995. Rezensionen: R. Hiltscher. In: Kant-Studien (Berlin) 91, 2000, 234-239.

WIMMER, Reiner: Kants philosophischer Entwurf Zum ewigen Frieden und die Religion. In: PKC (8), 1.1, 113-120.

\section{6}

Baumgartner, Hans Michael: Gott und das ethische gemeine Wesen in Kants Religionsschrift. Eine spezielle Form des ethiko-theologischen Gottesbeweises? In: Kant in der Diskussion der Moderne. Hrsg. von Gerhard SCHORNRICH und Yasushi KaTO. Frankfurt a. M. 1996, 408-424.

Brady, Jules M.: New Approaches to God. Based on Proofs by Anselm, Aquinas, and Kant. North Andover, MS, 1996.

Camera, Francesco: Unità della ragione e idea teologica in Kant. In: Lineamenti di un personalismo teologico. Scritti in onore di Carlo Arata. Hrsg. von L.MaluSA, G. Benelli, A. Campodonoco und B. Salmona. Genova 1996, 377-416.

CARSON, Emily Jane: Mathematics, Metaphysics, and Intuition in Kant. Univ. Diss.: Harvard Univ. 1996.

ChIEREnghein, Franco: Recenzione della teologia kantiana negli scritti giovanili di Hegel. In: Il "regno dei fini» in Kant. Hrsg. von Armando Rigobello. Neapel 1996, 147-172. 
CRAMER, Konrad: Metaphysik und Erfahrung in Kants Grundlegung der Ethik. In: Kant in der Diskussion der Moderne. Hrsg. von Gerhard SCHÖING und Yasushi KaTO. Frankfurt a. M. 1996, 280-325.

CRESCINI, Angelo: Il trascendentale contenuto metafisico della realtà. In: Giornale di Metafisica (Genova) [N. S.] 18, 1996, 243-257

Crichlow, Harold E.: Kant and Hegel: Their Religious Philosophies Compared. In: Bulletin of the Hegel Society of Great Britain (Colchester) 33, 1996, 87-102.

DONEV, Georgi: Transzendentalnijat sematisam kato graniza mejdu kriticnata i dogmaticnata metafisika [Der transzendentale Schematismus als Grenze zwischen der kritischen und der dogmatischen Metaphysik]. In: Filosofija (Sofija) 5-6, 1996, 39-43.

FraCHEHEIM, Emil L.: The God Within. Kant, Schelling, and Historicity. Hrsg. von John Burbridge. Toronto/Buffalo/London 1996. - Darin: Kant's Philosophy of Religion, 319; Kant and the Radical Evil, 20-33.

FAGGiotro, Pietro: La metafisica kantiana della analogia: Ricerche e discussioni. Trento 1996. R. S. Marcucci. In: Studi kantiani (Pisa) 10, 1997, 215-222.

Galbraith, Elizabeth C.: Kant and Richard Schaeffler's Catholic Theology of Hope. In: Philosophy and Theology (Milwaukee, WI) 9, 1996, 333-350.

GianNeTto, Giuseppe: Principio di ragione e metafisica in Leibniz e Kant. Napoli 1996. Rezensionen: G. L. Linguiti. In: Studi kantiani (Pisa) 10, 1997, 203-204.

Gill, Jerry H.: Kant, Analogy, and Natural Theology [1984]. In: Immanuel Kant's Prolegomena to Any Future Metaphysics in focus. Hrsg. und eingeleitet von Beryl LOGAN. London 1996, 241-253.

HARE, John E.: The Moral Gap: Kantian Ethics, Human Limits and God's Assistance. Oxford, NY 1996. Rezensionen: R. Paden. In: The Review of Metaphysics (Washington) 52, 1999, 680-681. Rezensionen: L. Zagzebski. In: The Philosophical Review (Ithaca, NY) 1999, 291-293. S. Palmquist. In: Kant-Studien (Berlin) 91, 2000, 498-502.

Hayling Fonseca, Annie: Relectura heideggeriana de Kant: el tiempo como horizonte ontológico y posibilidad de la metafísica. In: Revista de Filosofía de la Universidad de Costa Rica 34, 1996, 311-322.

HOWARD-SNyder, Daniel - O'LEARY-, John: Are Beliefs About God Theoretical Beliefs? Reflections on Aquinas and Kant. In: Religious Studies (Cambridge, UK/ New York) 32, Nr. 2, 1996, 233-258.

HsUeH-Chu, Maria: Die Einheit der Wirklichkeit. Kants Gotteslehre in metaphysischer Perspektive. Frankfurt a. M. u. a. 1996. Rezensionen: G. Cavallar. In: Zeitschrift für philosophische Forschung (Frankfurt a. M.) 52, 1998, 460-470 [Sammelrezension].

JACOBELLI IsOLDI, Angela Maria: Criticismo trascendentale, trascendenza, religione. In: Giornale di Metafisica (Genova) 18, 1996, 321-338.

Kant e la Filosofia della Religione. Istituto di Scienze Religiose in Trento. Hrsg. von Nestore PIRILLO. Einfuihrung: N. Pirillo (7-22). Trento 1996. - Darin: ANTISERI, Dario: La filosofia kantiana e la cultura cattolica, 637-660; BASSI, Simonetta: Tocco storiografo neokantiano, 627-634; BOF, Giampiero: Kant e la teologia protestante del '900, 703-738; CACCIATORE, 
Giuseppe: Kant, Dilthey e il problema della religione, 563-571; CaNTlloO, Giuseppe: Troeltsch e Kant: la Religionsphilosophie, 165-175; CARRANO, Antonio: Lessing e Kant: verità storiche e verità eterne, 273-292; CESA, Claudio: Linfluenza della Religione, 461-481; CUNICO, Gerardo: La teodicea etica-teleologica, 417-442; D'AlSESSANDRO, Giuseppe: Allegoria e verità nello Streit sull'interpretazione kantiana delle sacre scritture, 543-561; DE PASCALE, Carla: Lettori italiani della filosofia della religione di Kant nella prima metà del secolo, 591-626; EsPOSITO, Costantino: Sulla dottrina kantiana della religione, 223-246; FABBIO, Adolfo: La religione al di là della metafisica e della fenomenologia, 695-702; FABRIS, Adriano: "Come cerchi concentrici": significati e implicazioni di una metafora kantiana, 211-221; FARINA, Marcello: Un intellettuale trentino a confronto con Kant: Giovanni Battista Albertini (1742-1820), 673-693; FERRETTI, Giovanni: Le tensioni dell'ermeneutica cristologica di Kant, 113-131; FonNESSU, Luca: Kant, Leibniz e la "Aufklärung»: ottimismo e teodicea, 443-457; GiACOMINI Paola: Teologia e teleologia nella Kritik der Urteilskraft, 259-272; GrILlO, Andrea: Immanuel Kant "maestro" di Wilhelm Herrmann, 739-754; HINSKE, Norbert: La critica della ragione pura e lo spazio lasciato aperto alla fede, 25-38; IVALDO, Marco: La filosofia della religione fra Kant e Fichte. Sul Versuch einer Critik aller Offenbarung, 483-517; MALTER, Rudolf: La prima ricezione de La religione nei limiti della semplice ragione, 179-191; MANGANARO, Paolo: Il male della ragione, 39-52; MIEGGE, Mario: Figure moderne del "Mysterium iniquitatis", 193-209; MODA, Aldo: Karl Barth lettore di Kant, 755-778; MORI, Massimo: Felicità, virtù e religione in Kant, 53-79; NeUfELD, Karl H.: La recezione di Kant nella teologia cattolica, 661-671; Pellegrino, Ubaldo: Il problema di Dio nell'ultimo Kant, 395-416; PIrulo, Nestore: Il giuramento e il tribunale della coscienza, 81-111; RAJO, Giulio: Simbolismo e ontoteologia nei Fortschritte, 247-257; RoTTA, Graziella: La recezione di Kant nella disputa sull'ateismo del 1798-99, 519-542; RUGGENINI, Mario: I “limiti della semplice ragione», l'abisso, l'esperienza della finitezza, 367-394; SALA, Giovanni B.: Le vie della ragione alla ricerca di Dio secondo Kant: dall'ordine della natura all'imperativo della coscienza, 295326; SCHRŎDER, Hermann: Lo scritto di Kant sulla religione: una quarta Critica?, 133163; Sichirollo, Livio: Il male radicale. Eric Weil lettore di Kant, 573-589; VENTURELLi, Domenico: Interpretazioni kantiane del peccato d'origine, 343-366; VERWEYEN, Hans Jürgen: La dottrina filosofica di Dio in Kant, nell'orizzonte di una teologia dopo Auschwitz, 327-341.

Kogan, Jacobo: La filosofía trascendental como acceso a la metafísica [1961]. In: Kogan, Jacobo: Temas de Filosofía. Buenos Aires 1996, 113-120.

KORSGARD, Christine M.: Creating the Kingdom of Ends. Cambridge 1996. Rezensionen: P. Stratton-Lake. In: Kantian Review (Cardiff) 1, 1997, 177-185; A. W. Wood. In: The Philosophical Review (Ithaca, NY) 107, 1998, 607-611. - Darin: An Introduction to the Ethical, Political, and Religious Thought of Kant, 3-42.

MAsmela, Carlos: Presupuestos metafísicos de la Crítica de la razón pura. Antioquia 1996. Rezensionen: D. Leserre. In: Kant-Studien (Berlin) 92, 2001, 219-223.

ODERO, José Miguel: Actualidad del concepto kantiano de "religión». In: fLU (Madrid) 1, 1996, 105-124.

ODero, José Miguel: Fe y esperanza del hombre. Un diálogo con Kant. In: Esperanza del hombre y revelación bíblica. XIV Simposio Internacional de Teología de la Universidad de Navarra (Pamplona, 14-16 de abril 1993). Edición dirigida por J. M. CASCIARO, G. Aranda, F. Varo, J. Chapa. Pamplona 1996, 253-265. 
OJZERman, T[eodor] I.: Kants Metaphysik der Freiheit [russisch]. In: Voprosy Filosofii (Moskva) 6, 1996, 66-77.

Pereboom, Derk: Kant on God, Evil, and Teleology. In: Faith and Philosophy (Wilmore, KY) $13,1996,508-533$.

PÉrez-PAOLI, Ubaldo: Der moralische Begriff Gottes und Kants Auseinandersetzung mit Leibniz. In: Antike Weisheit und moderne Vernunft. Osnabrück 1996, 159-179. [Osnabrücker Philosophische Schriften Reihe A, Nr. 1]

Romerales Espinoza, Enrique: Sobre el concepto trascendental de Dios en Kant. In: Pensamiento (Madrid) 52, 1996, 337-360.

SAlA, Giovanni B.: La prova morale dell'esistenza di Dio negli scritti di Kant. In: Studi kantiani (Pisa) 9, 1996, 47-67.

SCHUSSLER, Ingeborg: Symbolique et métaphysique. La beauté comme symbole de la liberté chez Kant. In: Art et vérité. Hrsg. von Ingeborg Schüssler, Raphael Célis und Alexander Schild. Lausanne 1996, 145-163.

STARK, Werner: Der Marburger Streit um das Verhältnis der Philosophie Kants zur Religion. In: Kant-Studien (Berlin) 87, 1996, 89-117.

VentURElli Domenico: Etica e metafisica. Alcune riflessioni di Kant sulla filosofia di Platone. In: Giornale di Metafisica (Genova) 18 [N. S.], 1996, 215-226.

BACIU, Claudiu: Critic|, filosofie transcendental| Ói metafizic| la Tn Kant [Kritik, Transzendental-philosophie und Metaphysik Immanuel Kants]. In: Revista de Filosofie (Bukarest) 44, Nr. 3, 1997, 253-261.

BAUR, Jörg: Philosophie im Ausgriff auf konkrete Religion. Kants Umgang mit dem Topos "Orthodoxie». In: Neue Zeitschrift für systematische Theologie und Philosophie (Berlin/ New York) 39, 1997, Nr.2, 191-203.

BECK, Lewis White: Six Secular Philosophers. Religious Themes in the Thought of Spinoza, Hume, Kant, Nietzsche, William James, and Santayana. Revised Edition. Bristol 1997.

CABEDO, Salvador: Religión y paz en Kant. In: Kant: la paz perpetua, doscientos años después. Hrsg. von Vicent Martínez Guzmán. Valencia 1997, 35-51.

CANTnLLO, Giuseppe: Troeltsch e Kant: «apriori" e «storia» nella filosofia della religione. In: Lo storicismo e la sua storia: Temi, problemi, prospettive. Hrsg. von Giuseppe CaNTILlO, Giuseppe CACCIATORE und GiuseppeLISSA. Milano 1997, 334-342.

COCKBURN, David: Religious Pluralism and Kantian Metaphysics. In: Theology (Evanston, IL) 100,1997, Nr. 794, 117-122.

CunNighaM, Henri-Paul: La doctrine kantienne du souverain Bien et son modèle aristotélicien: équivocisme, univocisme, analogie? In: Droit et vertu chez Kant. Kant et la philosophie grecque et moderne. Actes du IIle Congrès de la Société Internationale d'Etudes Kantiennes de Langue Française. Athènes, 14-17 mai 1997. Athènes 1997, 225-230. 
Devillairs, Laurence: Kant et le piétisme. In: Revue d'Histoire et de Philosophie Religieuse (Strasbourg) 77, 1997, 453-465.

DONEV, Georgi: Metafizi...eskata intuicija i logikata na ezika [Metaphysische Intuition und Logik der Sprache]. Chumanizßm, Kultura, Religija. Materiali ot nau...nite konferencii. Sofija 1997, 88-97.

FAgGiotto, Pietro: La colomba di Kant: Nota sul rapporto tra metafisica ed esperienza. In: Giornale di Metafisica (Genova) 19, 1997, 501-507.

FERrETI, Giovanni: Ontologia e teologia in Kant. Torino 1997. Rezensionen: Th. S. Hofmann. In: Kant-Studien (Berlin) 91, 2000, 241-245.

Fiorato, Pierfrancesco: Die Erfahrung, das Unbedingte und die Religion. Walter Benjamin als Leser von Kants Theorie der Erfahrung. In: Hermann Cohen's Philosophy of Religion. Hrsg. von Stéphane Moses und Hartwig Wiedebach. International Conference in Jerusalem 1996. Hildesheim/New York 1997, 71-84.

FIORENTINO, Fernando: Filosofia e religione in S. Tommaso e Kant. Napoli/ Bari 1997.

GODlOVE, Terry F., jr.: Religion, Interpretation, and Diversiry of Belief: The Framework Model from Kant to Durkheim to Davidson, Macon, GA, 1997.

Heiddeger, Martin: Kant and the Problem of Metaphysics. Übersetzt von Richard Taft. Bloomington 1997.

KANAWRON, Valentin: Kak e vßzmoñno religioznoto apriori? [Wie ist das religiöse Apriori möglich?] In: Chumanizßm, Kultura, Religija. Materiali ot nau...nite konferencii. Sofija 1997, 76-87.

Kosteneley, Albert Mitchell: Kant and Religious Passion. Phil. Diss.: University of Oklahoma, 1997.

Mariña, Jacqueline: Kant on Grace: A Reply to His Critics. In: Religious Studies (Cambridge, UK/ New York) 33, 1997, 379-400.

MARTY François: La naissance de la métaphysique chez Kant. Une étude sur la notion kantienne d'analogie. Paris 1997.

Michaison, Gordon E.: The Problem of Salvation in Kant's Religion Within the Limits of Reason Alone. In: International Philosophical Quarterly (New York) 37, 1997, 319-328.

MOREROD, Charles: La connaissance de Dieu chez Kant. In: Nova et Vetera (Fribourg) 72, 1997, Nr. 2, 69-94.

NUYEN, A. T.: The Sublimity of Evil [Kant]. In: International Journal of Philosophy of Religion (Dordrecht u.a.) 41, 1997, 135-147.

Oesterreich, Peter L.: Das gelehrte Absolute. Metaphysik und Rherorik bei Kant, Fichte und Schelling. Darmstadt 1997. Rezensionen: E. Ostermann. In: AZPh 23, 1998, 293-296. H. P. Hempel. In: Philosophischer Literaturanzeiger (Frankfurt a. M.) 53, 2000, 326-327. R. Pozzo. In: Kant-Studien (Berlin) 92, 2001, 241-243.

OJZERMAnN, Teodor I.: Etikoteologija Kanta i ee sovremmenoe znacenie [Kants ethische Theologie und ihre moderne Bedeutung]. In: Voprosy Filosofii (Moskau) 1997, Nr. 3, 103-114. 
O'NeILl, Onora: Kant on Reason and Religion. In: The Tanner Lectures on Human Values (Salt Lake City) 18, 1997, 267-308.

Philonenko, Alexis: Métaphysique et politique chez Kant et Fichte. Paris 1997.

SCHUSSLER, Ingeborg: Linterprétation de la conscience morale chez Kant: du sentiment à la religion. In: Droit et vertu chez Kant. Kant et la philosophie grecque et moderne. Actes du Ille Congrès de la Société Internationale d'Études Kantiennes de Langue Française. Athènes, 14-17 mai 1997. Athènes 1997, 105-115.

SCHULZ, Michael: Sein und Trinität. Systematische Erörterungen zur Religionsphilosophie G. W. F. Hegels im ontologiegeschichtlichen Rückblick auf J. Duns Scotus und I. Kant und die Hegelrezeption in der Seinsauslegung und Trinitätstheologie bei Pannenberg, Jüngel, Rahner und v. Balthasar. St. Ottilien 1997.

SOMMER, Andreas Urs: Felix peccator? Kants geschichtsphilosophische Genesis-Exegese im Muthmaßlichen Anfang der Menschengeschichte und die Theologie der Aufklärungszeit. In: Kant-Studien (Berlin) 88, 1997, 190-217.

Strawson, Peter F.: Kant's New Foundation of Metaphysics [11987]. In: STrawson, Peter F.: Entity and Identity and Other Essays. Oxford/ New York 1997, 232-243.

SynNestvedT, Dan. A.: Kantian Religion: Relating Humans, God, and Nature. Phil. Diss.: Temple University 1997.

THEIS, Robert: En quel sens l'«Unique fondement possible d'une démonstration de l'existence de Dieu" de Kant est-il "unique" fondement "possible»? In: Revue Philosophique de Louvain 95, 1997, 7-23.

THEIS, Robert: Kants Theologie der bloßen Vernunft in der Kritik der reinen Vernunft. In: Philosophisches Jahrbuch der Görresgesellschaft (München) 104, 1997, $19-51$.

WaldaU, Knut: Das Problem der Denkmöglichkeit der notwendigen Existenz Gotres bei Immanuel Kant. Neuried 1997. [Univ. Diss.: München 1997]

WALS, W. H.: Kant's Criticism of Metaphysics. Edinburgh 1997.

WojtowICZ, Randy: The Metaphysical Expositions of Space and Time. In: Synthese (Dordrecht) 113, 1997, 71-115.

BAUM, Hermann: Kant: Moral und Religion. St. Augustin 1998.

CaVallar, Georg: Kants Religionsphilosophie im Spiegel neuerer Arbeiten. In: Zeitschrift für philosophische Forschung (Frankfurt a. M.) 52, 1998, 460-470. [Zu: Fackenheim 1996, Axinn 1994, Dell'Oro 1994, Ricken/ Marty 1992, Hsüeh-chu Chang 1996.]

CrocketT, Clayton Scott: The Theological Sublime: Subjectivity, Temporality and Imagination in the Kantian Critique. Diss.: Syracuse University, 1998.

DierskemeIer, Claus: Das Noumenon Religion. Eine Untersuchung zur Stellung der Religion im System der prakrischen Philosophie Kants. Berlin/New York 1998. [KSEH 133] Rezensionen: G. Cavallar. In: Kant-Studien (Berlin) 91, 2000, 119-122; U. Roth. In: Philosophisches Jahrbuch der Görresgesellschaft (München) 107, 2000, 528-529. 
FORSTER, Eckart: Die Wandlungen in Kants Gotteslehre. In: Zeitschrift für philosophische Forschung (Frankfurt a. M.) 52, 1998, 341-362.

Glouberman, Mark: Im-manual Can't: Activity, Cognition, God, and Transcendental Idealism. In: Iyyun (Jerusalem) 47, 1998, 235-264.

LiLlA, Mark: Kant's Theological-Political Revolution. In: The Review of Metaphysics (Washington) 52, 1998, 397-434.

LogAN, Beryl: Hume and Kant on Knowing the Deity. In: International Journal for Philosophy of Religion (Dordrecht/ Hingham) 43, 1998, Nr.3, 133-148.

ODERO, José Miguel: Actualidad del argumento kantiano. In: Filosofía contemporánea y cristianismo. Dios, hombre y praxis. Hrsg. von I. Murillo. Madrid 1998, 45-54.

QUiNTANILla NAVARro, Ignacio: Tecnología y metafísica: ¿hacia el final de una era kantiana? In: Diálogo Filosófico (Madrid) 14, 1998, 27-44.

RADNER, Michael: Unlocking the Second Antinomy: Kant and Wolff. In: The Journal of the History of Philosophy (Berkeley, CA) 36, 1998, 413-441.

SALEM-Wiseman, Jonathan: Beyond the Artist-God? Mimesis, Aesthetic Autonomy, and the Project of Philosophical Modernity in Kant, Nietzsche, and Heidegger. Diss.: York University, 1998.

Serrano, Manuel G.: Yo, sustancia y causas. Notas sobre la metafísica kantiana. In: Diálogo Filosófico (Madrid) 41, 1998, 211-228.

SKaR, qystein: Kant, religion, og bibelen i Der Streit der Fakultäten. In: Tidsskrift for Teologi og Kirkc (Oslo) 69, 1998, Nr. 3, 175-192.

STRANGAS, Johannes: I rapporti tra fondamentalismo religioso ed esperienza giuridica in quanto modo di emergenza del problema dei rapporti tra morale e diritto. In: Rivista Internazionale della Filosofia del Dirito (Milano) 5, 1998, 418-461.

TAFANI, Daniela: Ragion pratica e religione in Kant: Note su un recente convegno. In: Giornale Critico di Filosofia Italiana (Firenze) 18, 1998, Nr. 3, 475-482.

THEIS, Robert: Kant über rationale Theologie in seinen Vorlesungen über Metaphysik aus den $80 \mathrm{er}$ und $90 \mathrm{er}$ Jahren. In: Königsberg-Studien. Beiträge zu einem besonderen Kapitel der deutschen Geistesgeschichte des 18. und angehenden 19. Jahrhunderts. Hrsg. von Joseph KOHNEN. Frankfurt a. M. u.a., 1998, 221-255.

Wolterstoff, Nicholas: Is It Possible and Desiderable for Theologians to Recover from Kant? In: Modern Theology (Cambridge, MA) 14, 1998, Nr.1, 1-18.

Wood, Allen W.: Kant's Critique of the Three Theistic Proofs [partial], from Kant's Rational Theology. In: Kan's Critique of Pure Reason. Hrsg. von Patricia Kitcher. Lanham 1998, 265-282.

Andrade Nuevo, Vera Cristina de: Kant e a Metafísica. Uma longa história contada em dois ou três episódios. In: Verdade, Conhecimento e Ação. Ensaios em Homenagem a Guido Antônio de Almeida e Raul Landim Filho. Hrsg. von Edgar da R. MARQUeS, Ethel M. Rocha, Lia LeVY et al. São Paulo 1999, 67-80. 
CAPrI Orlando: Il problema dell'esistenza di Dio in Kant. In: Divus Thomas (Bologna) 102, $1999,54-90$.

CARMANN, Martin: Mensch: Moral - Religion. Kant-Lektüren aus der polykontexturalen Gesellschaft. Frankfurt a. M./ Berlin/ Bern u. a. 1999.

CATTIN, Emmanuel: Kant: La souveraine intention et le cher féal. In: Figures du théologicopolitique. Hrsg. von E. CaTtin, L. Jafro und A. PeTtT. Paris 1999, 229-249.

CONRADT, Michael: Der Schlüssel zur Metaphysik. Zum Begriff rationaler Hoffnung in Kants kritischer Moral- und Religionsphilosophie. Univ. Diss.: Tübingen, 1999.

D'AlESSANDRO, Giuseppe: Die Wiederkehr eines Leitworts: «Die Bestimmung des Menschen» als theologische, anthropologische und geschichtsphilosophische Frage der Spätaufklärung. [Abbt, Mendelssohn, Kant.] In: Aufklärung (Hamburg) 1, 1999, Nr. 1, 21-45.

Firestone, Christ L.: Kant and Religion: Conflict or Compromise? In: Religious Studies (Cambridge) 35, 1999, Nr. 2, 151-171.

FISCHER, Norbert: Die Cardinalsätze der Metaphysik in der Kritik der reinen Vernunft. Fünf Thesen zu Kants "Revolution der Dnkart» gemäß den "ersten Gedanken des Copernicus». In: Theologie und Glaube (Paderborn) 89, 1999, 349-363.

FISCHER, Wolfgang: Die Religion in Kants Begründung der Pädagogik. In: KaUder, Peter FISCHER, Wolfgang: Kant über Pädagogik. 7 Studien. Baltmannsweiler 1999, 173-211.

FREl, Andreas: Religion und Vernunft. Kants Interpretation der Genesis in Muthmaßlicher Anfang der Menschengeschichte. In: Kant als politischer Schriftsteller. Hrsg. von Theo Stammen. Würzburg 1999, 87-108.

Grosos, Philippe: Philosophie et théologie de Kant à Schelling. Paris 1999.

HutGiNs, Patrick: The Sublimes and Natural Theology - Kant as a Critical-Visionary? Lyotard as the Discoverer of a New Sublime? And That Sublime Both Leibnizian and CryptoThomist? In: Sophia (Victoria, Austr.) 38, 1999, Nr. 2, 15-35.

JaCHMANN, Reinhold Bernhard: Prüfung der kantischen Religionsphilosophie in Hinsicht auf die ihr beygelegte Aehnlichkeit mit dem reinen Mystizism. Mit einer Einleitung von Immanuel Kant. Reprint d. Ausg. Königsberg 1800. Mit einem Vorwort und Registern hrsg. von Robert THEIS. Hildesheim 1999.

KLEMME, Heiner F.: Die Freiheit der Willkür und die Herrschaft des Bösen. Kants Lehre vom radikalen Bösen zwischen Moral, Religion und Recht. In: Aufklärung und Interpretation. Hrsg. von Heiner F. Klemme, Bernd Ludwig, Michael Pauen und Werner Stark. Würzburg 1999, 125-151.

KuEHN, Manfred: Der Objektbegriff bei Christian Wolff und Immanuel Kant. In: Aufklärung und Interpretation. Studien zu Kants Philosophie und ihrem Umkreis. Hrsg. von Heiner F. Klemme, Bernd Ludwig, Michael Pauen und Werner Stark. Würzburg 1999, 39-56.

LONG, D. Stephen: Making Theology Moral [Kant]. In: Scottish Journal of Theology (Edinburgh) 52, 1999, 306-327.

Michalson, Gordon E., Jr.: Kant and the Problem of God. Oxford 1999. Rezensionen: A. W. Moore. In: Kantian Review (Cardiff) 4, 2000, 155-158. 
MÜlLER, Ernst: "Gerichtsbarkeit bis in die verborgensten Winkel des Herzens». Ästhetische Religiosität als politisches Konzept (Kant - Schiller - Humboldt). In: Ästhetik des Politschen - Politik des Ästhetischen. Hrsg. von Karlheinz BARCK und Richard FABER. Würzburg 1999, 121-135.

Müller, Ernst: Die "verschleierte Isis» der Vernunft. Kants Ästhetik und die Depotenzierung der Religion. In: Deutsche Zeitschrift für Philosophie (Berlin) 47, 1999, 553-571.

PIRNI, Alberto: La Fondazione della metafisica dei costumi e il Regno dei fini: problema normativo e problema religioso in Kant. In: La trasmissione della filosofia nella forma storica. Atti del XXXIII Congresso Nazionale della Società Filosofica Italiana. Hrsg. von Luciano Malusa. Vol. II: Comunicazioni e documenti. Milano 1999, 139-147.

PrivetTe, Jeffey S.: Must Theology Re-Kant? In: The Heythrop Journal (London) 40, 1999, 166-183.

PulTe, Helmur: Von der Physikotheologie zur Methodologie. Eine wissenschaftstheoriegeschichtliche Analyse der Transformation von nomothetischer Teleologie und Systemdenken bei Kant und Fries. In: Jakob Friedrich Fries. Philosoph, Naturwissenschaftler und Mathematiker. Hrsg. von Wolfram HoGREBE und Kay HERRMANN. Bern/ Berlin u.a. 1999, 301-351.

SHAW, Brian J.: Habermas and Religious Inclusion: Lessons from Kant's Moral Theology. In: Political Theory (London) 27, 1999, Nr. 5, 634-666.

VAZQUeZ LOBEIRAS, María Jesús: La ética kantiana como una parte de la metafísica. In: Moral, derecho y política en Immanuel Kant. Hrsg. von Julián CarVAJAL CORDÓN. Ediciones de la Universidad de Castilla-La Mancha. Cuenca 1999, 321-332.

VEENBASS Jabik: Religie en vrijheid bij Kant. Een dichotomie in Kant godsdienstfilosofie opnieuw geanalyseerd. In: Algemeen Nederlands Tijdschrift voor Wijsbegeerte (Assen) 91, 1999, Nr. 4, 253-268.

VINATY, Bernard: Le Dieu indémontrable et indubitable de Kant. In: God and Argument. Hrsg. von William SWEET. Ottawa 1999, 153-173.

WEST, J. L. A.: Kant's Attack on the Cosmological Argument. In: God and Argument. Hrsg. von William SWEET. Ottawa 1999, 175-187.

ADAMS, Robert Merrihew: God, Possibility, and Kant. In: Faith and Philosophy (Wilmore, $\mathrm{KY}) 17,2000,425-440$.

BARTZ, Werner - KREIMENDAHL, Lothar: Bericht über Band II der Akademie-Ausgabe der Schriften Kants auf der Grundlage einer Untersuchung der Schrift Der einzig mögliche Beweisgrund zu einer Demonstration des Daseins Gottes. In: Kant-Studien (Berlin) 91, 2000, Sonderheft, 17-19.

Breavers, Anthony F.: Kant and the Problem of Ethical Metaphysics. In: Philosophy in the Contemporary World (San Antonio, TX) 7, 2000, Nr. 2-3, 11-20. 
Bowles, Brian Hansford: Sensibility and Transcendence in Kant and the Problem of Metaphysics. In: Philosophy Today (New York) 44, 2000, 347-365.

CAIMI, Mario: Einige Bemerkungen über die metaphysische Deduktion in der Kritik der reinen Vernunft. In: Kant-Studien (Berlin) 91, 2000, Nr. 3, 257-282.

D'AlESSANDRO, Giuseppe: Kant e l'ermeneutica. La Religione kantiana e gli inizi della sua recezione. Soveria Mannelli (Catanzaro) 2000.

DEKENS, Olivier: La réduction de Dieu. Kant, Levinas et la possibilité d'un athéisme métaphysique. In: Revue de Théologie et de Philosophie (Lausanne) 132, 2000, 309324.

FAGGGIOTTO, Pietro: Nota sul concetto kantiano di metafisica come disposizione naturale. In: Studi kantiani (Pisa) 13, 2000, 11-17.

FERRARI, Jean: Sur la notion kantienne de la finalité. In: La finalité en question. Philosophie et sciences contemporaines. Actes du colloque de Dijon 25-27 mars 1999. Hrsg. von Michel BASTIT und Jean-Jacques WUNENBURGER. Paris/Montréal 2000, 145-159.

Geismann, Georg: Sittlichkeit, Religion und Geschichte in der Philosophie Kants. In: Jahrbuch für Recht und Ethik (Berlin) 8, 2000, 437-531.

Gentile, Andrea: Metafisica del "limite» e strutture del trascendentale. In: Passione dell'originario. Fenomenologia ed ermeneutica dell'esperienza religiosa. Studi in onore di Armando Rigobello. Hrsg. von Emilio BACCARINI. Roma 2000, 97-134.

GrapotTE, Sophie: L'unique fondement possible d'une démonstration de l'existence de Dieu. In: Une philosophie dans l'histoire. Hrsg. von Bjarne MELKEVICK und Jean-Marc NARBONNE. Paris/ Québec 2000, 325-343.

Grondin, Jean: La actualidad de La religión dentro los límites de la mera razón de Kant. In: Ideas y Valores (Bogotá) 2000, Nr. 113, 2000, 80-85.

GrondiN, Jean: Zur Phänomenologie des moralischen, Gesetzes'. Das kontemplative Motiv der Erhebung in Kants praktischer Metaphysik. In: Kant-Studien (Berlin) 91, 2000, 385-394.

Grossman, Reinhardt: Der ontologische Ursprung des Kantischen Idealismus. In: Neue Ontologie und Metaphysik. Hrsg. von Raffael HơnTELMANN und Erwin TeGTMEIER. St. Augustin 2000, 97-105.

HARE, John E.: Kant on Recognizing Our Duties As God's Commands. In: Faith and Philosophy (Wilmore, KY) 17, 2000, 459-478.

HeNRICH, Dieter: Systemreform und Abschlussgedanke. Methode und Metaphysik als Problem in Kants Denken. In: Information Philosophie (Lörrach) 2000, Nr. 5, 7-21.

Kant and Kierkegaard on Religion. Hrsg. von D. Z. PHILLIPS und Timothy TeSSIN. London 2000. - Darin: Evans, C. Stephen: Kant and Kierkegaard on the Possibility of Metaphysics, 3-24; FerReIRA, M. Jamie: Making Room for Faith - Possibility and Hope [Zu Gill], 73-88; GiLl, Jerry H.: Faith Not without Reason: Kant, Kierkegaard and Religious Belief, 55-72; GrEEN, Ronald M.: Kant and Kierkegaard on the Need for a Historical Faith: an Imaginary Dialogue, 131-152; HARE, John E.: Kant's Divine Command Theory and Its Reception within Analytic Philosophy, 263-277; 
PalmQUIST, Stephen: Philosophy and Religion after Kant and Kierkegaard, 245-262; RUHR, Mario von der: Kant and Kierkegaard on Eternal Life - a Reply [zu Whittaker], 207-235; WestON, Michael: Kant and Kierkegaard on the Possibility of Metaphysics a Reply to Professor Evans, 25-44; WHITAKeR, John H.: Kant and Kierkegaard on Eternal Life, 187-206; VERHEYDEN, Jack: The Ethical and the Religious as Law and Gospel [zu Green], 153-177.

LANGTHALER, Rudolf: Gottvermissen - Eine theologische Kritik der einen Vernunft. Die neue Politische Theologie (J. B. Metz) im Spiegel der kantischen Religionsphilosophie. Regensburg 2000.

LONGUENESSE, Béatrice: Point of View of Man or Knowledge of God: Kant and Hegel on Concept, Judgment, and Reason. In: The Reception of Kant's Critical Philosophy. Fichte, Schelling and Hegel. Hrsg. von Sally SEDGWICK. Cambridge 2000, 253-282.

McCormicK, Matt: Why God Cannot Think: Kant, Omnipresence, and Consciousness. In: Philo (Amherst, NY) 3, 2000, 5-19.

Mastrogregori, Massimo: La religione dei ricordi [Croce, Kant]. In: Belfagor (Firenze) $55,2000,527-536$.

MoscaTo, Alberto: Esistenza e necessità nell'Unico argomento possibile per una dimostrazione dell'esistenza di Dio di Kant. In: MosCATO, Alberto: Metafisica e intelligibilità. Studi di filosofia teoretica. Hrsg. von Francesco Camera. Genova 2000, 81-98; ders.: La dottrina del metodo nella Ricerca sull'evidenza dei principi della teologia naturale e della morale di Kant, ibid., 99-118.

MOXTER, Michael: Subjektivität und Kontingenz. Wandlungen im Rationalitätsverständnis zwischen Kant und Schleiermacher. In: Vernunft, Kontingenz und Gott. Hrsg. von Ingolf DALFERTH und Philipp STOELleger. Tübingen 2000, 193-212.

NARAGON, Steve: The Metaphysics Lectures in the Academy Edition of Kant's gesammelte Schriften. In: Kant-Studien (Berlin) 91, 2000, Sonderheft, 189-215.

OVERHOFF, Jürgen: Immanuel Kant, die philanthropische Pädagogik und die Erziehung zur religiösen Toleranz: In: Immanuel Kant und die Berliner Aufklärung. Hrsg. von Dina EMUDTS. Staatsbibliothek zu Berlin - Preußischer Kulturbesitz. Ausstellungskatalog Nr. 38 [Neue Folge]. Wiesbaden 2000, 133-147.

PalmQuist, Stephen R.: Kant's Critical Religion. Volume Two of Kant's System of Perspectives. Hampshire 2000. Rezensionen: Th. A. Russman. In: The Review of Metaphysics (Washington) 56, No. 1, 2002, 197-198.

PerEZ, Daniel Omar: (Des-)Articulação dos problemas da metafisica (Classificaçōes, transformaçōes e conseqüências da teoria silogística de Kant). In: Manuscrito (São Paulo) 23, 2000, Nr. 1, 147-184.

PIRNI, Alberto: Il regno dei fini in Kant. Morale, religione e politica in collegamento sistematico. Genova 2000. Rezensionen: G. Marini. In: Studi kantiani (Pisa) 14, 2001, 237-240; A. Pinzani. In: Zeitschrift für philosophische Forschung (Frankfurt a. M.) 56, 2002, 165-166.

PORTMANN, Franz: Einheit aus der Metaphysik. Eine alternative Rekonstruktion der Kantischen Lehre. Freiburg 2000. 
RESCHER, Nicholas: Kant on the Limits and Prospects of Philosophy - Kant, Pragmatism, and the Metaphysics of Virtual Reality. In: Kant-Studien (Berlin) 91, 2000, 283-328.

SALA, Giovanni B.: Die Christologie in Kants «Religion innerhalb der Grenzen der bloßen Vernunft". Weilheim-Bierbronnen 2000. [Schriftenreihe der Gustav-SiewerthAkademie 15.]

SCHWAIGER, Clemens: Ein "missing link" auf dem Weg der Ethik von Wolff zu Kant. Zur Quellen- und Wirkungsgeschichte der praktischen Philosophie von Alexander Gottlieb Baumgarten. In: Jahrbuch für Recht und Ethik (Berlin) 8, 2000, 247-261.

SEDGWICK, Sally: Metaphysics and Morality in Kant and Hegel. In: The Reception of Kant's Critical Philosophy. Fichte, Schelling and Hegel. Hrsg. von Sally SEDGWICK. Cambridge 2000, 306-323.

SMITH, James K. A.: Re-Kanting Postmodernișm? Derrida's Religion within the Limits of Reason Alone. In: Faith and Philosophy (Wilmore, KY) 17, 2000, 558-571.

STANGNETH, Bettina: Kultur der Aufrichtigkeit. Zum systematischen Ort von Kants "Religion innerhalb der Grenzen der bloßen Vernunft». Würzburg 2000.

Tifdemann, Dietrich: On the Nature of Metaphysics: An Examination of Professor Kant's Principles - Against the Aesthetic. [Hessische Beyträge zur Gelehrsamkeit und Kunst 1, 1785, 113-130.] In: Kant's Early Critics. The Empiricist Critique of the Theoretical Philosophy. Übersetzt, eingeleitet und hrsg. von Brigitte SASSEN. Cambridge 2000, 81-92; 199-209.

VAiHInger, Hans: The Philosophy of "As If": A System of the Theoretical, Practical, and Religious Fictions of Mankind. Ubersetzt von C. K. Ogden. London 2000. [Reprint der Ausg. von 1924.]

WELSEN, Peter: Gott und die Ubel der Welt. Zum Problem der Theodizee bei Leibniz, Kant und Schopenhauer. In: der blaue reiter (Stuttgart) Nr. 10, 2000: Götter, 33-37.

\section{1}

AmERIKS, Karl: Kant's Lectures on Metaphysics and his Precritical Philosophy of Mind: Unearthing the Unsaid. In: New Essays on the Precritical Kant. Hrsg. von Tom ROCKMORE. Amherst, NY, 2001, 19-36.

Années 1796-1803. Kant. Opus postumum. Philosophie, Science, Ethique et Théologie. Actes du 4e Congrès international de la Societé d'études kantiennes de langue française, Lausanne, 21-23 octobre 1999. Sous la direction de Ingeborg SCHÜSSLER édité par Christophe ErISMANN. Paris 2001.

ASMUTH, Christoph: Von der Kritik zur Metaphysik. Der transzendentalphilosophische Wendepunkt Kants und dessen Wende bei Fichte. In: Umbrüche. Historische Wendepunkte der Philosophie von der Antike bis zur Neuzeit. Hrsg. von Klaus KaHNERT. Amsterdam 2001, 167-187.

ASSEL, Heinrich: Geheimnis und Sakrament. Die Theologie des göttlichen Namens bei Kant, Cohen und Rosenzweig. Göttingen 2001. [Forschungen zur systematischen und ökumenischen Theologie, Bd. 98.] 
Cramer, Konrad: Peripetien der Ontologie - Wolff, Kant, Hegel. In: Die Weltgeschichte das Weltgericht? Stuttgarter Hegel-Kongress 1999. Hrsg. von Rüdiger BUBNER und Walter MESCH. Stuttgart 2001, 176-207.

CROKETT, Clayton: A Theology of the Sublime. [Kant and Postmodernism.] London/ New York 2001.

FALKENBURG, Brigitte: Kants Forderungen an eine wissenschaftliche Metaphysik der Natur. In: Architektonik und System in der Philosophie Kants. Hrsg. von Hans Friedrich FULDA und Jürgen STONZELBERG. Hamburg 2001, 307-327.

FERretI, Giovanni: Ontologie et théologie chez Kant. Relire Kant après Heidegger et Lévinas. Trad. de l'italien par P. Chapel de la Pachevie. Paris 2001.

FukUMITSU, Mizue: Kants Gottesbegriff und seine kopernikanische Wende. Hamburg 2001.

HeINZ, Marion: Herder's Review of Dreams of a Spirit-Seer (1766). In: New Essays on the Precritical Kant. Hrsg. von Tom RoCKMORE. Amherst, NY, 2001, 110-128.

JANKE, Wolfgang: Restitution der metaphysischen und transzendentalen Deduktion. Überlegungen zur existenzial-ontologischen Vertiefung des transzendentalen Prinzips. In: Transzendenz und Existenz. Idealistische Grundlagen und moderne Perspektiven des tanszendentalen Gedankens. Hrsg. von Manfred Baum und Klaus HaMmaCHER. Amsterdam/ Atlanta 2001, 195-213.

Kant i Kantovata tradicija v Bßlgarija. [Kant und die Kantische Tradition in Bulgarien]. Hrsg. von Ivan StefanOV, Valentin KanAWrow und Dimitßr Zazov. Sofija: Verlag LiK, 2001. - Darin: Dimitrova, Nina: Sergej Bulgakov i "transcendentalnijat problem za religijata" [Sergij Bulgakov und "das transzendentale Religionsproblem»], 370-384; G'OSEV, Christo: Transcendentalnata analitika, predstavena kato metafizika [Die transzendentale Analytik als Metaphysik dargestellt], 176-180; PANOVA, Elena: Kant i analiti...nata filosofija (Za edna "kriti...eska" metafizika) [Kant und die analytische Philosophie (Zur großen "kritischen" Metaphysik)], 116-124; SIvov, Kalin: Bog, moralnijat zakon i mjastoto na ...oveka vßv vselenata [Gott, Moralgesetz und die Stellung des Menschen im Weltall], 189-202; STEFANOV, Ivan S.: Filosofijata na razuma: ot kritika kßm metafysika [Philosophie der Vernunft: von der Kritik aus zur Metaphysik], 125-135; TEOCHAROV, Vladimir: Transcendentalnata teologija v Kantovata tradicija [Die transzendentale Theologie in der Kantischen Tradition], 159-165; TEOCHAROV, Vladimir: Iniciacijata "Bog e mßrtßv» [Die Initiation "Gott ist tot»], 166-175.

Kant und die Berliner Aufklärung. Akten des IX. Internationalen Kant-Kongresses. 5 Bde. Hrsg. i. A. der Kant-Gesellschaft e.V. von Volker GerhardT, Rolf-Peter HortSMAnN und Ralph SCHUMACHER. Berlin/New York 2001. - Darin: BiRD, Graham H.: Two Kinds of Descriptive Metaphysics: Kant and Strawson, Bd. 2, 533540; BuCHheIM, Thomas: Die Universalität des Bösen nach Kants Religionsschrift, Bd. 3, 656-665; D'Alessandro, Giuseppe: Kant und Tieftrunk: Die Religion innerhalb der Grenzen der Vernunft - Ein Beitrag zur Entstehungsgeschichte der Religionsphilosophie Kants, Bd. 3, 641-648; DE PIERRIS, Graciela: Geometry in the Metaphysical Exposition, Bd. 2, 197-204; FRICKE, Christel: Kants Theorie des guten Willens zwischen empiristischer Konsenstheorie und Crusianischer Moraltheologie, Bd. 3, 202-210; HeNRICK, Dieter: Systemform und Abschlussgedanke - Methode und Metaphysik als Problem in Kants Denken, Bd. I: Hauptvorträge, 94-115; HIMI, 
Kiyoshi: Das radikale Böse und die menschliche Freiheit in der Religionsschrift Kants, Bd. 3, 674-681; Hoyos, Luis Eduardo: Deskriptive Metaphysik, Transzendentalphilosophie und nachkantischer philosophischer Skeptizismus, Bd. 4, 490-499; JONG GOOK Kim: Moralirät in der Gott-verlassenen Welt. Theodizeefrage bei Kant und Jonas, Bd. 3, 682-688; LANGTHALER, Rudolf: ,Gedächtnis und Erinnerung' im Kontext der kantischen Geschichts- und Religionsphilosophie, Bd. 4, 375-385; MODEL, Anselm: Zur Mehrdeutigkeit des Terminus ,Metaphysik' bei Kant, Bd. 2, 638-645; MoorS, Martin: Von Tugendpflicht zur Religion: Vernunftbedürfnis und Mimesis in der Moral Kants, Bd. 3, 689-695; MULLer, Ernst: Kants Symbolbegriff in Ästhetik und Religionstheorie - Zum Ursprung des Begriffs in den Träumen eines Geistersehers, Bd. 3, 596-603; OZMEN, Elif: Uber Kants Träume der Metaphysik. Versuch einer entwicklungsgeschichtlichen Einordnung, Bd. 2, 44-51; ORTHLAND, Eberhard: Kants Ästhetik-Konzeption vor dem Hintergrund seiner Auseinandersetzung mit der Physikotheologie, Bd. 3, 604614; RovirA, Rogelio: Von der mannigfachen Bedeutung der Metaphysik nach Kant, Bd. 2, 646-655; TCHERNOV, Serguei A.: Kants Metaphysik der Wissenschaft: zwanzig Thesen und eine Bemerkung, Bd. 4, 643-647; SCHERER, Irmgard: Revisiting Kant's General Metaphysics: in Terms of a Completed Transcendental Psychology, Bd. 4, 424-432; SilTONEN, Arto: Die Religionsschrift Kant und der reine Rationalismus, Bd. 3, 704-712; STEVENSON, Leslie: Is there any Hope for Kant's Account of Religion? Bd. 3, 713-720; VelKLEY, Richard: On Possibility in Concepts: A Note on the Metaphysical Problem in Kant, Bd. 2, 506-511; YaMane, Yûichirô: Von der "Erwerbung" zur «ursprünglichen Erwerbung". Ein Querschnitt durch die Entstehungsgeschichte der kritischen Metaphysik, Bd. 2, 691-699; Zammito, John H.: Kant and the Schönen Wissenschaften: Contextualizing the Dreams of a Spirit-Seer, Bd. 2, 78-85.

LAWRENCE, Joseph P.: Moral Mysticism in Kant's Religion of Practical Reason. Kant's Legacy: Essays in Honour of Lewis White Beck. Hrsg. von Predrag CICOVACKI. Rochester 2001, 311-331.

LAYWINE, Alison: Kant in Reply to Lambert on the Ancestry of Metaphysical Concepts. In: Kantian Review (Cardiff) 5, 2001, 1-48.

MARIŃA, Jacqueline: The Religious Significance of Kant's Ethics. In: American Catholic Philosophical Quarterly (Charlottesville, VA) 75, 2001, 179-200.

MbuYn, Mukendi: Kants Tübinger Kritiker. Die Kritik von Johann Friedrich Flatt an Kants moralischem Argument für die Annahme Gottes. Aachen 2001.

Michalson, Gordon E., jr.: God and Kant's Ethical Commonwealth. In: The Thomist (Washington) 65, 2001, 67-92.

NODE-LANGloIS, Michel: La critique kantienne des preuves de l'existence de Dieu. In: Revue Thomiste (Toulouse) 109, 2001, 531-564.

PIRNI, Albert: Il regno dei fini e la sua prospettiva: intersoggettività morale, religiosa e giuridica in Kant. In: Prospettive della morale kantiana. Hrsg. von Domenico Venturelli. Acqui Terme 2001, 75-114.

SALA, Giovanni B.: Die Gottesfrage in den Schriften Kants. In: Zeitschrift für katholische Theologie (Freiburg) 123, 2001, 143-171. 
SCHNEPF, Robert: Metaphysik oder Metaphysikkritik? Das Kausalitätsproblem in Kants Abhandlung Über die negativen Größen. In: Archiv für Geschichte der Philosophie (Berlin/ New York) 83, 2001, 130-159.

SCHWAIGER, Clemens: Vollkommenheit als Moralprinzip bei Wolff, Baumgarten und Kant. In: Vernunftkritik und Aufklärung. Studien zur Philosophie Kants und seines Jahrhunderts. Hrsg. von Michael OBERHAUSEN unter Mitwirkung von Heinrich P. Delfosse und Riccardo Pozzo. Stuttgart-Bad Cannstatt 2001, 317-328.

SEIDL, Horst: Sein und Bewusstsein. Erörterungen zur Erkenntnislehre und Metaphysik in einer Gegenüberstellung von Aristoteles und Kant. Hildesheim 2001.

SHELl, Susan Meld: Kant as Educator: Reason and Religion in Part One of the Conflict of the Faculties. In: Kant's Legacy: Essays in Honour of Lewis White Beck. Hrsg. von Predrag CicovacKi. Rochester 2001, 333-367.

THEIS, Robert: Gottes Spur in der Welt? Kant über den Optimismus um die Mitte der 1750er Jahre. In: Vernunftkritik und Aufklärung. Studien zur Philosophie Kants und seines Jahrhunderts. Hrsg. von Michael OBERHAUSEN unter Mitwirkung von Heinrich P. Delfosse und Riccardo Pozzo. Stuttgart-Bad Cannstatt 2001, 351-363.

VELKLEY, Richard L.: Metaphysics, Freedom, and History: Kant and the End of Reason. In: American Catholic Philosophical Quarterly (Charlottesville, VA) 75, 2001, 153-170.

VOELLER, Carol W.: The Metaphysics of the Moral Law. Kant's Deduction of Freedom. New York/ London 2001 [revidierte Fassung der Erstveröffentlichung 1998].

ATKINSON, Robert Elliot: Space, Time and Ethical Foundations. Ashgate 2002.

BicKMANn, Claudia: Zur systematischen Funktion der Kantischen Ideenlehre. In: Perspektiven der Transzendentalphilosophic im Anschluß an die Philosophie Kants. Hrsg. von Reinhard Hiltscher und André Georgi. Freiburg/ München 2002, 43-79.

BONDELI, Martin: Zum ontologischen Status von Kants „ursprünglich-synthetischer Einheit der Apperzeption“. In: Interpretation und Argument. Hrsg. von Helmut LINNEWEBERLAMMERSKITTEN und Georg MOHR. Würzburg 2002, 155-170.

BRACHTENDORF, Johannes: Kants Theodizee-Aufsatz - Die Bedingungen des Gelingens philosophischer Theodizee. In: Kant-Studien (Berlin) 93, 2002, 57-83.

Chalier, Catherine: What Ought I to Do? Morality in Kant and Levinas. Aus dem Frz. übersetzt. Corncll 2002.

D'Alessandro, Giuseppe: Der Moralmensch. Anthropologie und Kantianismus in der Theologie und der Moralphilosophie am Ende des 18. Jahrhunderts. In: Aufklärung (Hamburg) 14, 2002, 97-122.

DEKENS, Olivier: Le Kant de Levinas. Notes pour un transcendantalisme éthique. In: Revue Philosophique de Louvain 2002, Nr. 1-2, 108-128.

DÜSING, Edith und Klaus: Negative und positive Theologie bei Immanuel Kant. Kritik des ontologischen Gottesbeweises und Gottespostulats. In: Societas rationis. FS für Burkhard Tuschling zum 65. Geburtstag. Hrsg. von Dieter HÜNIG, Gideon STIENING und Ulrich VOGEL. Berlin 2002, 85-118. 
DüsING, Klaus: Subjektivität und Freiheit. Untersuchungen zum Idealismus von Kant bis Hegel. Stuttgart-Bad Cannstatt 2002.

EngSTROM, Stephen: The Inner Freedom Virtue. In: Kant's Metaphysics of Morals. Interpretative Essays. Hrsg. von Mark TiMMONS. Oxford 2002, 289-315.

FISCHER, Norbert: Kants These vom Primat der praktischen Vernunft. Zu ihrer Interpretation im Anschluß an Emmanuel Lévinas. In: Religion, Moderne, Postmoderne: Philosophisch-theologische Erkundungen. Hrsg. von Klaus DETHLOFF. Berlin 2002, 229-262.

Garcia, Ernesto V.: A Kantian Theory of Evil. In: The Monist 85, 2002, 194-209.

GeRL-FALKOVITZ, Hanna-Barbara: Kant und Liturgie. Zwei unbekannte Skizzen des jungen Romano Guardini: „Kants Erkenntnislehre“ und „Wesen des Liturgischen“ (1913). In: Theologie und Philosophie (Freiburg) 77, 2002, 553-555.

GrImM, Stephen R.: Kant's Argument for Radical Evil. In: European Journal of Philosophy (Oxford) 10, 2002, 160-177.

GraU, Gerd-Günther: Von der absoluten Religion zu einer skeptischen Religiosität. Nietzsche - Kierkegaard - Kant. In: Religion - aber wie? Hrsg. von Heinz Robert SCHLETTE. Würzburg 2002.

HINTON, Timothy: Kant and Aquinas on the Priority of the Good. In: The Review of Metaphysics (Washington) 55, 2002, 825-846.

HWANG, SOON-U: Kants „Schlüssel“ für eine Ontologie im Legitimitätsproblem des Identitätsbewusstseins. Zur Kategoriendeduktion der Kritik der reinen Vernunft. Würzburg 2002

Immanuel Kant: Groundwork of the Metaphysic of Morals. Hrsg. von Lawrence PASTERNACK. London/ New York 2002.

Immanuel Kants „Grundlegung zur Metaphysik der Sitten“. Ein einführender Kommentar. Hrsg. von Dieter SCHÖNECKER und Allen W. WOOD. Paderborn 2002.

Kerstein, Samuel J.: Kant's Search fort he Supreme Principle of Morality. Cambridge 2002.

LAWRENCE, Jospeh R.: Radical Evil and Kant's Turn to Religion. In: The Journal of Value Inquiry (Hingham) 36, 2002, 319-335.

LOOSE, Donald: De metaforiek van het Rijk Gods bij Kant. In: Tijdschrift voor Filosofie (Leuven) 64, 2002, 533-564.

MojSISCH, Burkhard: Verbindung und Einheit bei Platon und Kant - mit metatheoretischen Reflexionen. In: Prudentia und Contemplatio. Ethik und Metaphysik im Mittelalter. Hrsg. von Johannes Brachtendorf. Paderborn u.a. 2002, 161-169.

ROHS, Peter: Kants Unterscheidung zwischen Kausalität nach der Natur und Kausalität aus Freiheit. In: Perspektiven der Transzendentalphilosophie im Anschluß an die Philosophie Kants. Hrsg. von Reinhard Hiltscher und André Georgi. Freiburg/München 2002, 157-178.

VRIES, Hent de: Religion and Violence. Philosophical Perspectives from Kant to Derrida. Baltimore 2002. 


\section{3}

KANT, Immanuel: Religion innerhalb der Grenzen der bloßen Vernunft. Mit einer Einleitung und Anmerkungen hrsg. von Betrina STANGNETH. Hamburg 2003. R: G. B. Sala. In: ThPh 79, 2004, 116-118.

BAHR, Petra: Darstellung des Undarstellbaren. Religionstheoretische Studien zum Darstellungsbegriff bei A. G. Baumgarten und I. Kant. Tübingen 2003

CAROPReSO, Paolo: Von der Dingfrage zur Frage nach Gott. Zum eigentlichen Ursprung von Religiosität in Kants Transzendentalphilosophie. Berlin /New York 2003. [KSEH 143.] R: U. L. Lehner. In: ThPh 79, 2004, 118-121.

Di GIOVANNI, George: Faith Without Religion, Religion Without Faith: Kant and Hegel on Religion. In: Journal of the History of Philosophy (Berkeley) 41, 2003, 365-383.

DuQue, Félix: Das Ende aller Dinge und der Wink des letzten Gottes. Heideggers Konzeption der Seinsgeschichte im Ausgang von Kant und Hegel. In: Heidegger im Zwiegespräch mit dem deutschen Idealismus. Hrsg. von Harald Seubert. Köln 2003, 155-171.

HAKE, Ann-Kathrin: Vernunftreligion und historische Glaubenslehre. Immanuel Kant und Hermann Cohen. Würzburg 2003.

IRLENBORN, Bernd: Die Bedeutung des Bösen in Kants praktischer Philosophie. Zur Grundlegung der Religionsschrift. In: PrPh 16, 2003, 407-423

MOORE, A. W.: Noble in Reason, Infinite in Faculty. Themes and Variations in Kant's moral and religious philosophy. London 2003.

OlivetTI, Marco M.: Zum Religions- und Offenbarungsverständnis beim jungen Fichte und Kant. In: Praktische und angewandte Philosophie I. Hrsg. von Helmut Girndt und Hartmut Traub. Amsterdam u.a. 2003, 191-201. [Fichte-Studien 23]

PIEPER, Annemarie: Der Streit zwischen Vernunft und Glaube. Descartes - Spinoza - Kant. In: Metamorphosen der Vernunft. FS für Karen Gloy. Hrsg. von Alessandro Lazzari. Würzburg 2003, 157-168.

RAGUZ, Ivica: Sinn für das Gott-Menschliche. Transzendental-theologisches Gespräch zwischen des Ästhetiken von Immanuel Kant und Hans Urs von Balthasar. Würzurg 2003.

RaY, Matthew Alun: Subjectivity and Irreligion. Atheism and Agnosticism in Kant, Schopenhauer, and Nietzsche. Bristol: Ashgate 2003.

Sherover, Charles M.: Experiential Time and the Religious Concern. [A Kantian Rethinking of Some Kant.] In: Are We In Time? And Other Essays on Time and Temporality. Hrsg. von Gregory R. Johnson. Evanson, IL, 2003, 69-89.

\section{4}

Kants Metaphysik und Religionsphilosophie. Hrsg. von Norbert FisCHER. Hamburg 2004. - Darin: BERG, Robert Jan: Das Verhältnis von Glauben und Wissen bei Kant und Hegel, 493-515; CAIMI, Mario: Kants Metaphysik und Religionsphilosophie in spanischen Arbeiten, 609-630; Coriando, Paola-Ludovika: Ich und die Seele. Zu Kants „Paralogismen der reinen Vernunft“, 21-42; DÖRflinger, Bernd: Führt Moral unaus- 
bleiblich zur Religion? Überlegungen zu einer These Kants, 207-223; DUSING, Edith: Gott als Horizont oder Grund des Ich? Von Kants praktischer Metaphysik zu Fichtes Metaphysik des Einen Seins, 433-491; ERB, Wolfgang: Kritische Religionsphilosophie und absolutes Nichts - Kant und die Ky?to-Schule, 663-694; ERTL, Wolfgang: Schöpfung und Freiheit: ein kosmologischer Schlüssel zum Verständnis von Kants Kompatibilismus, 43-76; Esposito, Costantino: Kant: von der Ethik zur Religion (und zurück), 265-291; FISCHER, Norbert: Die Zeit als Problem in der Metaphysik Kants, 409-431; FISCHER, Norbert: Kants Metaphysik der reinen praktischen Vernunft, 111-130; FORSCHNER, Maximilian: Freiheit als Schlussstein eines Systems der reinen Vernunft. Transzendentale und praktische Freiheit, 131-159; GreISCH, Jean: „Freiheit im Lichte der Hoffnung". Zu Paul Ricours Kantdeutung, 583-608; HerrmanN, Friedrich-Wilhelm von: Die „Kritik der reinen Vernunft“ als TranszendentalMetaphysik, 1-20; KOPPER, Joachim: Die Bedeutung der Methodenlehren, 391-407; LANGTHALER, Rudolf: „Man wird von der Philosophie den wirklichen Gott fordern, nicht die bloße Idee Gottes". Zur Kritik des späten Schelling an Kants Religionsphilosophie, 517-560; LEVINAS, Emmanuel: Le primat de la raison pure pratique/Das Primat der reinen praktischen Vernunft. Eingel., übers. und komm. von Jakob Sirovátka, 179-205; RICKEN, Friedo: Die Postulate der reinen praktischen Vernunft, 161-177; RUFFING, Margit: Muß ich wissen wollen? - Schopenhauers KantKritik, 561-582; SALA, Giovanni B.: Das Reich Gottes auf Erden. Kants Lehre von der Kirche als „ethischem gemeinen Wesen“, 225-264; Schulz, Peter: Gibt es eine kopernikanische Wende im Begriff des ,summum bonum'? Zur Wirkung von Kants praktischer Metaphysik im angelsächsischen Raum, 631-650; SCHWAIGER, Clemens: Denken des ,Übersinnlichen ' bei Kant. Zu Herkunft und Verwendung einer Schlüsselkategorie seiner praktischen Metaphysik, 331-345; SIROVÁTKA, Jakub: Slavica sunt, non leguntur. Kant est, non legitur. Zur Wirkung von Kants Metaphysik und Religionsphilosophie in den slawischen Ländern, 651-661; THEIS, Robert: Zur Topik der Theologie im Projekt der Kantischen Vernunftkritik, 77-110; WIMMER, Reiner: Homo noumenon: Kants praktisch-moralische Anthropologie, 347-390; WINTER, Aloysius: Die ,Endabsicht ' der Metaphysik vor, allen ihren Zurüstungen', 293-329. 